\title{
AULA EXPOSITIVA, SEMINÁRIO E PROJETO NO ENSINO DE ENGENHARIA: UM ESTUDO EXPLORATÓRIO UTILIZANDO A TEORIA DAS INTELIGÊNCIAS MÚLTIPLAS
}

\author{
Ana PAUla do CARMo Marcheti
}

Dissertação apresentada à Escola de Engenharia de São Carlos da Universidade de São Paulo, como parte dos requisitos para obtenção do título de Mestre em Engenharia de Produção.

Orientador: Prof. Dr. Renato Vairo Belhot

SÃO CARLOS 
A minha família e amigos, especialmente a meus pais, por todo apoio e compreensão durante todos os caminhos percorridos. 


\section{AGRADECIMENTOS}

Ao Prof. Associado Renato Vairo Belhot, amigo e orientador desse trabalho, pelo apoio, orientação e pelo grande exemplo na busca pelo conhecimento.

À Ângela Luísa Doretto pelo estímulo, exemplo, ajuda e amizade.

Aos amigos Nelma, Márcia e Egberto pela grande amizade e contribuição na minha vida pessoal e profissional.

Aos meus sobrinhos Fo e Du pelos sorrisos, carinhos e presença constante na minha vida.

A todas as pessoas que fazem parte da minha vida e me incentivam a continuar nessa caminhada pela busca do conhecimento e crescimento pessoal com carinhos, compreensão, conselhos e exemplos.

À Força Maior. 


\section{SUMÁRIO}

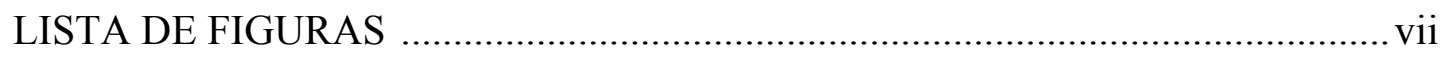

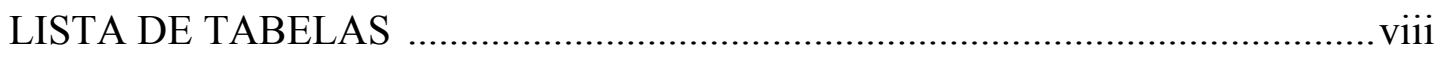

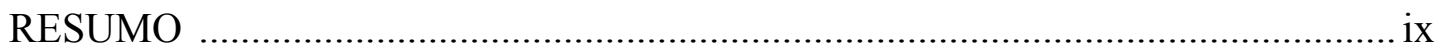

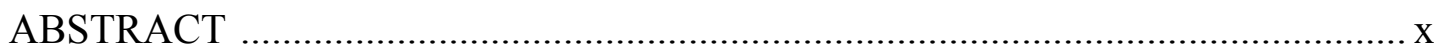

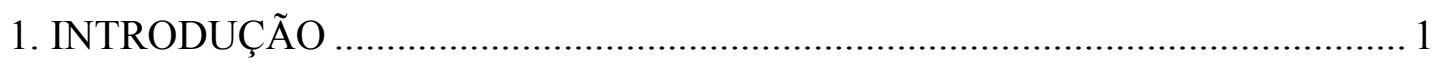

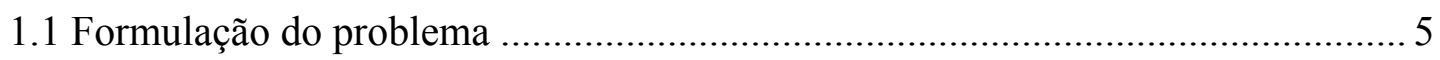

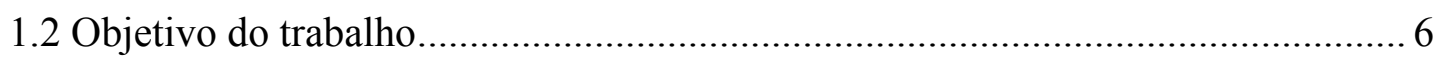

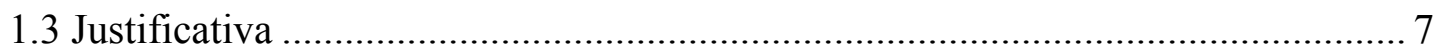

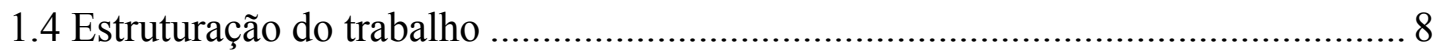

2. O MODELO DE ENSINO E AS TENDÊNCIAS DE MERCADO ....................... 10

2.1 O processo de globalização e a adaptação do processo de ensino e

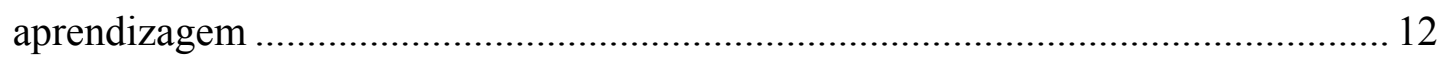

2.1.1 A educação no contexto socioeconômico ........................................................ 14

2.2 O mercado de trabalho e o ensino de engenharia............................................... 16

2.3 Tendência de mercado e evolução do processo de ensino e aprendizagem......... 19

3. PROCESSO TRADICIONAL DE PLANEJAMENTO DO ENSINO E

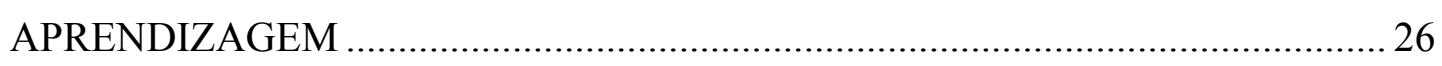

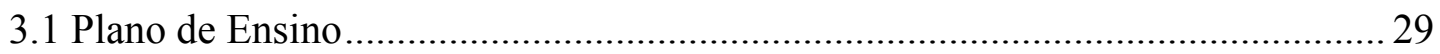

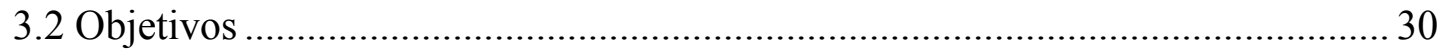

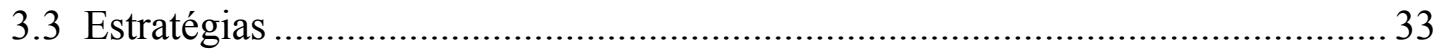

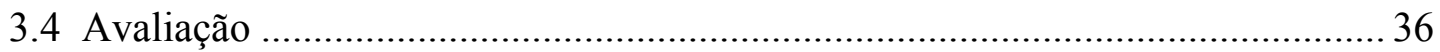

4 ESTRATÉGIAS DE ENSINO E APRENDIZAGEM ......................................... 38

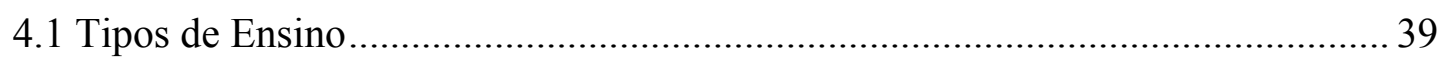

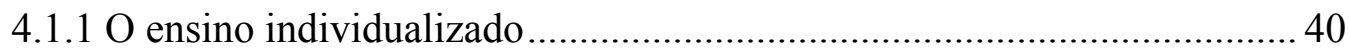

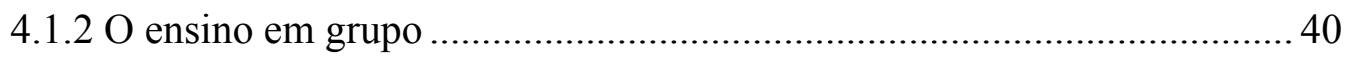

4.2 Estratégias que Auxiliam o Processo de Ensino e Aprendizagem....................... 42 
4.2.1 Situações simuladas que reproduzem ou se assemelham à realidade pela equivalência

4.2.2 Situações que colocam os estudantes em confronto com situações reais ......... 45

4.2.3 Estratégias que dividem a classe em pequenos grupos .................................. 46

4.2.4 Situações que exigem a presença de um especialista e/ou uma preparação prévia.

4.2.5 Estratégias em que o educador centraliza a ação ............................................ 50

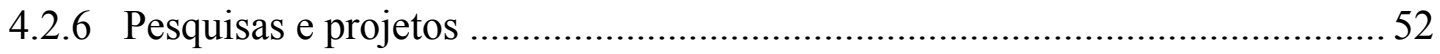

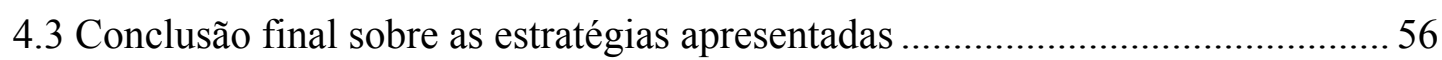

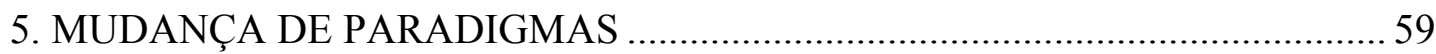

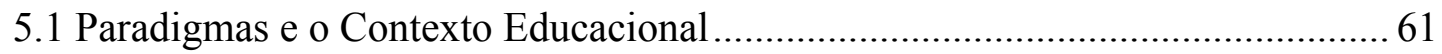

5.2 Potencial Humano - Uma Visão Histórica............................................................ 64

5.3 Contribuições para a Definição de Inteligência Humana..................................... 67

5.4. Pluralização do Conceito de Inteligência .......................................................... 71

6. TEORIA DAS INTELIGÊNCIAS MÚLTIPLAS ............................................ 74

6.1 Pré-requisito para ser Considerada uma Inteligência Dentro da Teoria das

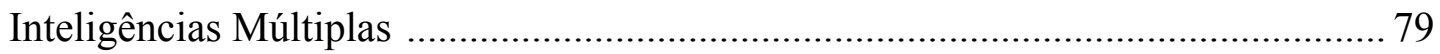

6.2 Tipos de Inteligencia - Teoria das Inteligências Múltiplas ................................. 82

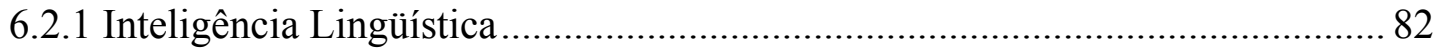

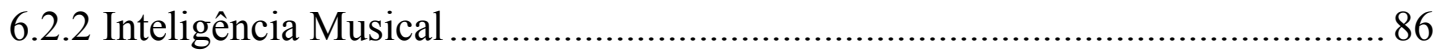

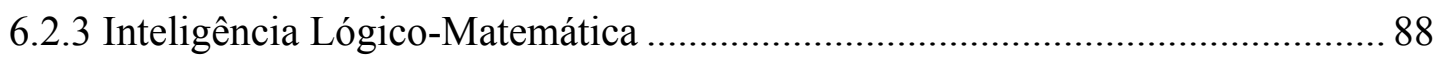

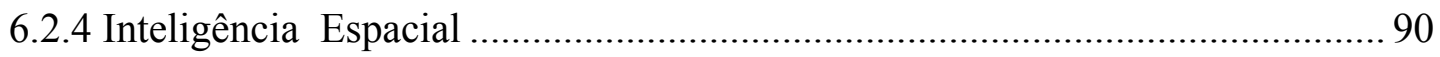

6.2.5 Inteligência Corporal-Cinestésica ................................................................. 92

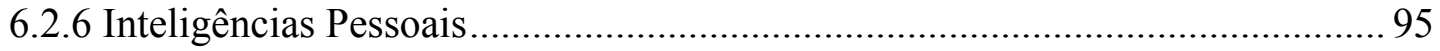

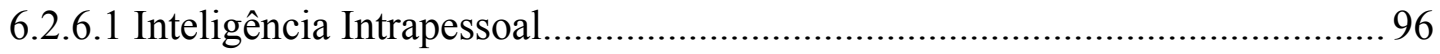

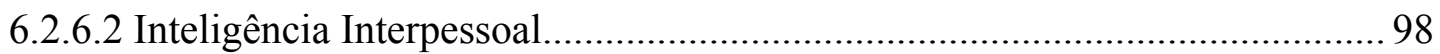

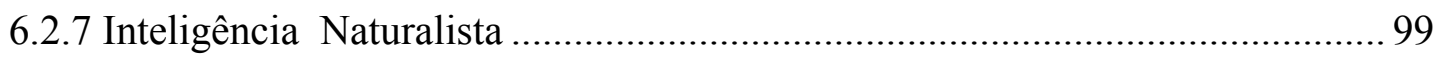

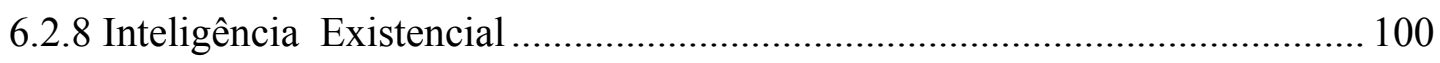

6.3 Inteligências Múltiplas - últimas considerações ............................................... 100 
7. A UTILIZAÇÃO DA TEORIA DAS INTELIGÊNCIAS MÚLTIPLAS AGREGADA ÀS ESTRATÉGIAS DE ENSINO: AULA EXPOSITVA, SEMINÁRIO E PROJETO ............................................................................ 104

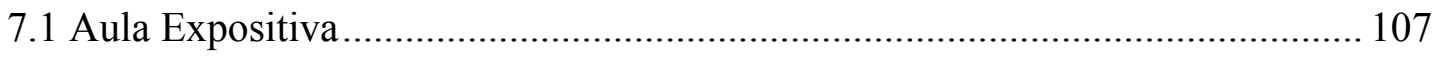

7.1.1 Aplicação dos princípios da comunicação na aula.......................................... 108

7.1.2 Vantagens da utilização da aula expositiva................................................. 112

7.1.3 A aula expositiva e sua relação com a Teoria das Inteligências Múltiplas.... 116

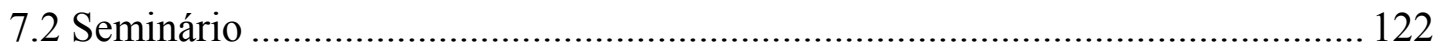

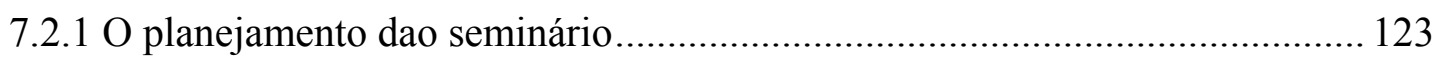

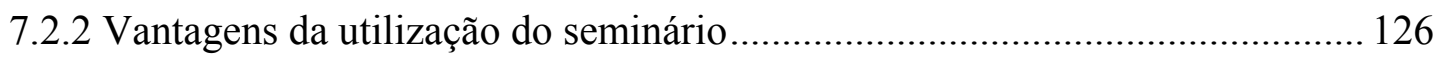

7.2.3 Desenvolvimento da estratégia seminário - algumas sugestões ...................... 126

7.2.4 Uso adequado do seminário e sua relação com a Teoria das Inteligências

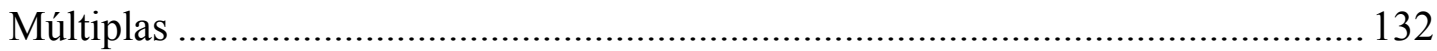

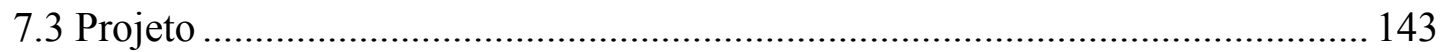

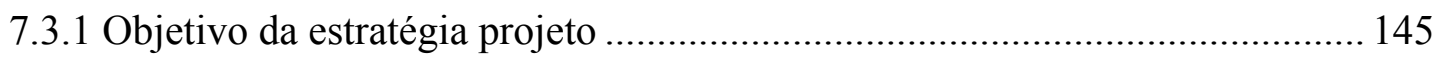

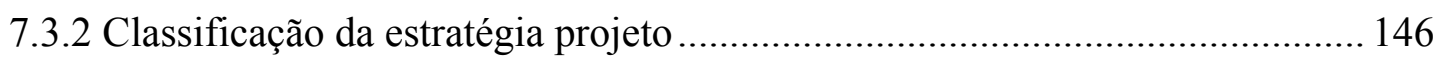

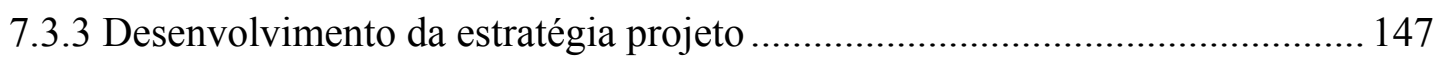

7.3.3.1 Orientação didática para o desenvolvimento de projetos.............................. 151

7.3.3.2 $\mathrm{O}$ que deve conter o planejamento de projeto ........................................... 153

7.3.4 Uso adequado do projeto e sua relação com a teoria das Inteligências Múltiplas

8. CONCLUSÃO 161

8.1 Como garantir o desenvolvimento, concomitantemente, de habilidades pessoais

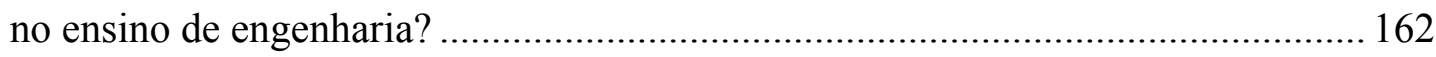

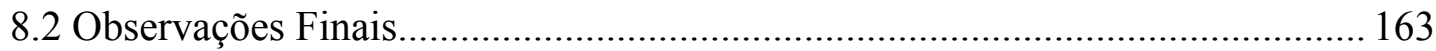

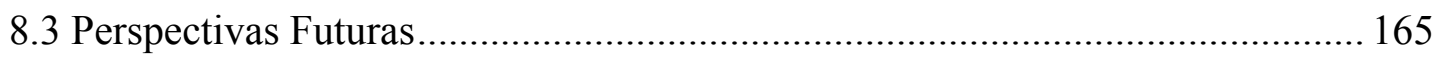

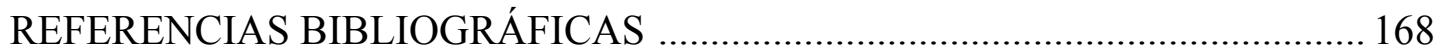

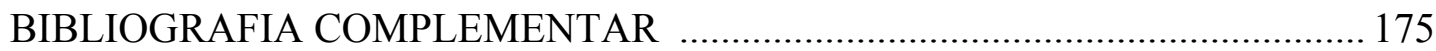




\section{LISTA DE FIGURAS}

FIGURA 1.1 - Instituição de Ensino Superior e o mercado profissional 03

FIGURA 1.2 - Teoria das Inteligências Múltiplas como ferramenta do processo de ensino/aprendizagem. .04

FIGURA 2.1 - O processo de globalização e sua co-relação com o ensino e mercado 14

FIGURA 2.2 - Mudança do foco do ensino 16

FIGURA 3.1. Plano de ensino tradicional e modificado 30

FIGURA 4.1 - Desenvolvimento da atividade de Pesquisa e de Projeto 54

FIGURA 4.2 - Ciclo de Aprendizagem por Pesquisa e Projetos 56

FIGURA 5.1 - Interdependência entre sociedade, educação e mercado: implicações no comportamento individual

FIGURA 7.1: Esquema básico do processo de comunicão relacionado ao processo de ensino e aprendizagem em uma aula expositiva, objetivando a assimilação da mensagem de forma satisfatória. 108

FIGURA 7.2: Seminário com o educador como coordenador 127

FIGURA 7.3: Seminário com o estudante como coordenador 128

FIGURA 7.4: Seminário sem coordenador específico 129 


\section{LISTA DE TABELAS}

TABELA 2.1 - Características pessoais e técnicas necessárias ao profissional que deseja atuar no mercado de trabalho atual 20

TABELA 4.1: Resumo das categorias e Estratégias de ensino. 57

TABELA 7.1: Resumo das principais características da Aula Expositiva. 115

TABELA 7.2: Aula expositiva, capacidades e inteligências estimuladas 117

TABELA 7.3 Aula Expositiva.capacidades, inteligencias estimuladas e momentos121

TABELA 7.4: Seminário, atividades e inteligências estimuladas 136

TABELA 7.5: Seminário: Conhecimento do material sobre o tema escolhido 138

TABELA 7.6: Seminário: Organização das idéias centrais do material encontrado139

TABELA 7.7: Seminário: Redigir a partir das idéias principais dos materiais lidos140

TABELA 7.8: Seminário: Estruturar a apresentação do material. 141

TABELA 7.9: Seminário: Apresentar o trabalho para outras pessoas 142

TABELA 7.10: Projeto - Etapas de um projeto e responsáveis pelo desenvolvimento 150

TABELA 7.11: Projeto - Problematização: atividade e inteligências estimuladas. 156

TABELA 7.12: Projeto - Desenvolvimento: atividade e inteligências estimuladas 157

TABELA 7.13: Projeto - Sintese: atividade e inteligências estimuladas. 159 


\section{RESUMO}

MARCHETI, A.P.C. (2001). Aula Expositiva, Seminário e Projeto no Ensino de Engenharia: Um Estudo Exploratório Utilizando a Teoria das Inteligências Múltiplas. São Carlos, 2000; 193p. Dissertação (Mestrado) - Escola de Engenharia de São Carlos. Universidade de São Paulo.

Durante muito tempo o cerne de muitos processos de ensino e aprendizagem têm sido o "aprender a aprender". As mudanças têm sido a característica mais estável ao longo dos tempos e é necessário adequar o processo de ensino e aprendizagem, para desenvolver profissionais melhores. O mercado atual provoca uma valorização de profissionais diferenciados, a aplicação de certas técnicas de gestão moderna exige competências específicas, e estas devem ser estimuladas no ambiente formal de aprendizagem (sala de aula). Nesse trabalho a incorporação da Teoria das Inteligências Múltiplas às estratégias de ensino aula: expositiva, seminário e projeto, dentro do curso de engenharia, tem como objetivo refletir sobre novas possibilidades de ensino que auxiliará o processo de aprendizagem e o desenvolvimento de características pessoais e técnicas necessárias ao profissional em formação.

Palavras-chaves: Ensino de Engenharia, Estratégias de Ensino; Múltiplas Inteligências 


\begin{abstract}
MARCHETI, A.P.C. (2001). Expositive Class, Seminar and Project at the Teaching of Engineering Process: An Exploratory Study Using The Multiples Intelligences Theory. São Carlos, 2000; 193p. Dissertação (Mestrado) - Escola de Engenharia de São Carlos. Universidade de São Paulo.
\end{abstract}

For a long time the heartwood of the learning and teaching process has been "how people can learn how to learn". Nowadays, the changing process due to economy globalization a high competitive imposed by social changes leads to some adjustments on the learning and teaching process. The stock option available has to be fulfilled by professional with specific and nonconventional capabilities. The present paper deals with those aspects, concerning the engineering teaching process and the new exigencies of performance, and introduces the Multiples Intelligences Theory into the higher education. The Multiples Intelligences Theory is one of the available tools to revitalize the engineering teaching situation by been incorporated into the teaching methods: expositive class, seminars and project, on behalf of the learning process and to the development of personal and technical capability needed by the professional been formed.

Keywords: Engineering education, teaching strategies, multiple intelligences 
CAPÍtULO 1

\section{INTRODUÇÃO}

O conceito de educação como o meio formal de profissionalizar indivíduos com valores pessoais definidos, com consciência de sua importância como cidadãos e capazes de se adaptar a uma sociedade mutante e globalizada, tem levado muitas instituições de ensino a procurem uma nova alternativa pedagógica, com finalidade de adicionar estas características ao desenvolvimento das habilidades técnicas já desenvolvidas no contexto educacional.

Seguindo este raciocínio de desenvolver habilidades adicionais, as organizações, cada vez mais, investem em treinamento, com a finalidade de melhorar a qualificação profissional dos seus colaboradores.

Essa ênfase maior dada ao desenvolvimento de características pessoais e profissionais complementares às técnicas, tanto a nível acadêmico como organizacional, está diretamente ligada a uma mudança na conscientização de que a aprendizagem deverá ser contínua e que é necessário muito mais que conhecimento técnico para se adquirir e se conservar um lugar no mercado de trabalho.

Essa mudança e conscientização da necessidade constante "aprender a aprender" já não causam tanto transtorno e desconforto dentro das Instituições de Ensino Superior e tampouco nas pessoas envolvidas no processo de capacitação profissional. Agora, faz-se necessário buscar uma 
solução para minimizar o descompasso entre mercado de trabalho e instituições de ensino, ou seja, encontrar formas de como trabalhar, num tempo predefinido, dentro de diretrizes e leis, os conceitos técnicos fundamentais que, de forma efetiva, desenvolvam habilidades pessoais específicas que melhor preparem para o mercado de trabalho os envolvidos no processo de ensino e aprendizagem.

Nos cursos de nível superior, a maior ênfase sempre foi dada à capacitação técnica específica da profissão escolhida, principalmente porque esta era a maior exigência do momento. Hoje, com as mudanças ocorridas, a ela outras tantas devem se acrescentar.

Nem toda mudança de mercado influência diretamente o modelo de ensino e aprendizagem. Por isso, mesmo percebendo uma mudança no mercado profissional, as Instituições de Ensino Superior demoraram a assimilar a as alternativas necessárias para suprir as necessidades mercadológicas da atualidade. Criando-se uma lacuna, até há pouco tempo discreta, entre o mercado de trabalho e o Ensino Superior, ou mais especificamente, entre a necessidade do desenvolvimento de habilidades profissionais pessoais fundamentais para a atuação no mercado de trabalho vigente e o desenvolvimento agregado à preparação técnica profissional (onde está o grande foco das Instituições de Ensino Superior). (FIGURA 1.1)

Hoje, tanto o desenvolvimento de características pessoais profissionais quanto da capacidade técnica, dentro das Instituições de Ensino Superior, são preocupações constantes de várias pessoas que atuam no processo de ensino e aprendizagem.

A conscientização de todas as características e habilidades pessoais que podem ser desenvolvidas durante a transmissão dos conhecimentos técnicos, talvez seja a primeira etapa para a minimização da lacuna entre conhecimento técnico e habilidades pessoais, minimizando os custos investidos por algumas empresas em programas de trainees, que objetivam 
desenvolver nos indivíduos, um pouco de consciência sobre a atuação profissional.

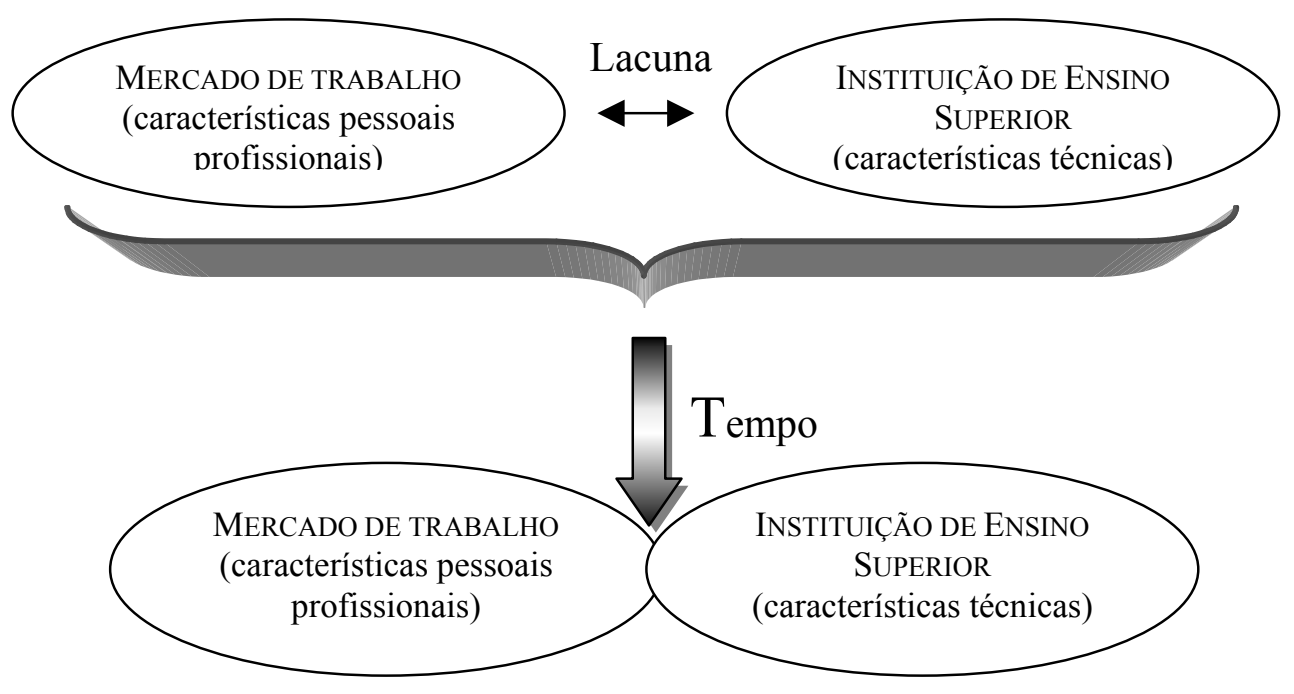

FIGURA 1.1 - Instituição de Ensino Superior e o mercado profissional: o intervalo de tempo das respostas das Instituições de Ensino Superior às necessidades profissionais pessoais do mercado é grande, fazendo que se crie uma lacuna entre o mercado e a capacitação profissional pessoal do indivíduo

Assim, é necessário buscar alternativas para que tanto a capacitação técnica quanto a pessoal, sejam realizadas com eficiência e com eficácia, atendendo as reais necessidades do mercado de trabalho atual.

Existem várias novas teorias educacionais e comportamentais. É preciso identificar dentre elas uma possibilidade que garanta um processo de ensino e aprendizagem das Instituições de Ensino Superior mais efetivo.

Dentre as várias alternativas existentes, a Teoria das Inteligências Múltiplas, proposta por Howard Gardner em Harvard, pode servir como uma forte aliada para o desenvolvimento de capacidades individuais, em conjunto com a preparação técnica que vem sendo realizada. Essa teoria leva em consideração que o ser humano é pluralista, ou seja, dotado de várias 
capacidades, chamadas de inteligências, que podem ser desenvolvidas de acordo com a necessidade e deficiência de cada um, a qualquer momento, a partir de estímulos, durante o processo de ensino e aprendizagem (GARDNER, 1994).

A Teoria das Inteligências Múltiplas possibilita, durante o processo de ensino e aprendizagem, o perfeito desenvolvimento do indivíduo de forma holística, ou seja socialmente, tecnicamente e individualmente. Trata-se do desenvolvimento simultâneo de habilidades pluralistas e especialistas. (FIGURA 1.2)

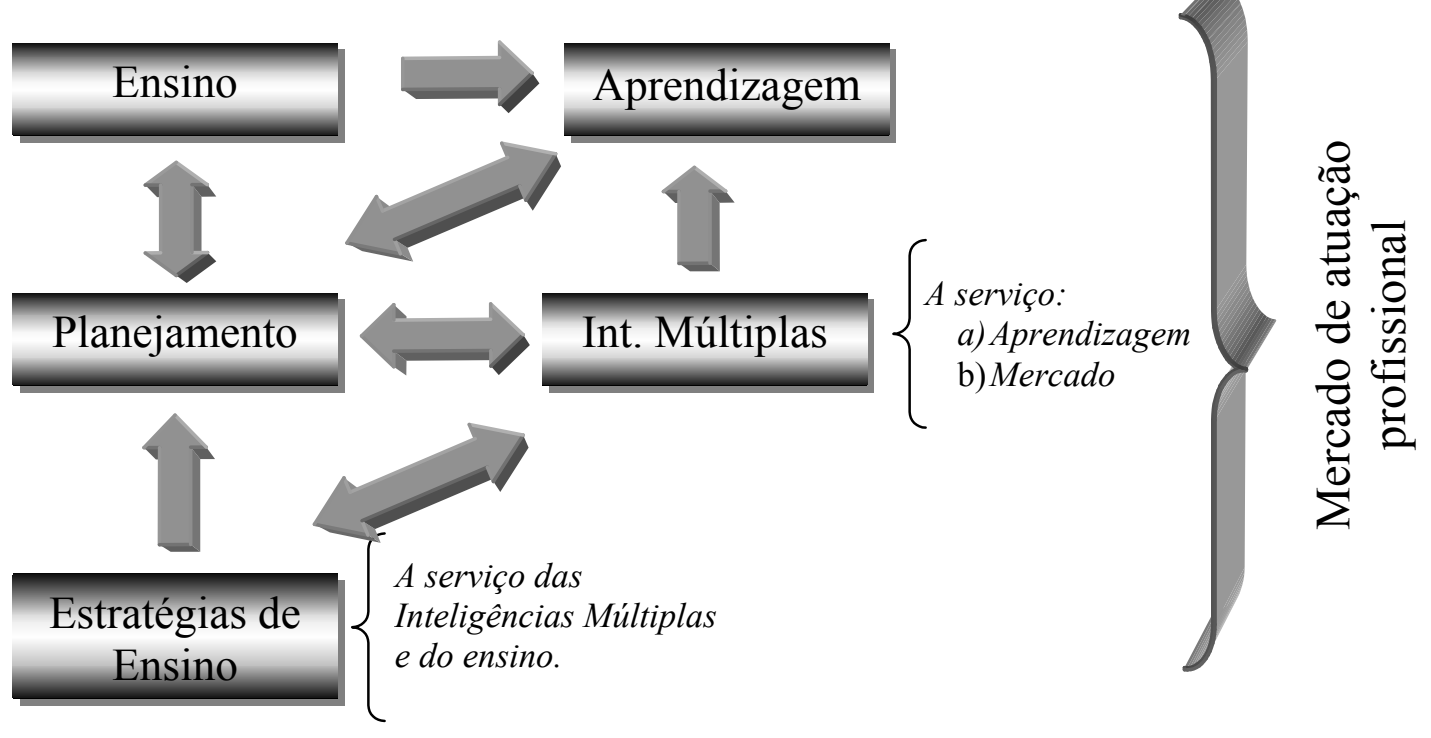

FIGURA 1.2 - Teoria das Inteligências Múltiplas como ferramenta do processo de ensino/aprendizagem: $O$ processo focado no ensino e aprendizagem com a finalidade de capacitar o indivíduo para suprir as necessidades profissionais do mercado, utilizando a Teoria das Inteligências Múltiplas como uma ferramenta direcionadora ara aplicação das estratégias de ensino, a realização do planejamento de ensino e o aprendizado efetivo dos envolvidos no processo 


\subsection{FORMULAÇÃO DO PROBLEMA}

A preocupação com a eficiência do processo de ensino e aprendizagem, e especificamente com o ensino de Engenharia, tem sido manifestada constantemente em diferentes eventos. Merece destaque o Congresso Brasileiro de Ensino de Engenharia - COBENGE, realizado anualmente e organizado em parceria Associação Brasileira de Ensino de Engenharia - ABENGE e as Instituições de Ensino Superior.

Com o advento da globalização e da socialização do saber muitas mudanças ocorreram em diferentes áreas e, especificamente, na educação aconteceu a conscientização de que para uma perfeita atuação no mercado de trabalho, o constante aprimoramento de técnicas e condutas seria necessário. Nesse contexto, a maior dificuldade recaiu no "Como aprender a aprender ?" neste novo ambiente.

Com o tempo a preocupação no como "aprender a aprender" para se adaptar a tamanhas mudanças foi minimizada, conforme conceitos como aprendizagem continuada, aprendizagem à distância, utilização dos diferentes recursos no processo de ensino e aprendizagem e de treinamentos foi sendo incorporados para melhor desenvolver características pessoais e profissionais nas pessoas

A todas estas mudanças veio agregada uma nova postura individual, e a melhoria dos cursos (profissionalizantes, graduação e/ou pós-graduação) significa trabalhar as variáveis presentes no meio acadêmico e direcioná-los para novas tendências, e vislumbrando uma perfeita adaptação pessoal do profissional no ambiente mercadológico e social em que está inserido.

Assim, é fundamental para se garantir a excelência do processo de ensino e aprendizagem, desenvolver no estudante, durante a graduação, o saber que dará sustentação a sua atuação profissional: a capacidade de trabalhar em equipe, de expressão, de raciocínio lógico, de "aprender a aprender", dentre outras. 
Dentre as novas tendências profissionais, as características pessoais como posturas e valores chegam a ser, em determinado momento, fundamentais para a atuação profissional no mercado atual (COLENCI, 2000).

A diminuição do ciclo vital de algumas tecnologias, produtos, serviços, informações que sustentam determinados conhecimentos, chega a ser menor que a esperada, com isso, o ensino de Engenharia vem ganhando dinamicidade bem maior e novas alternativas educacionais são necessárias para suprir o mercado, com profissionais capazes de atuar em um ambiente tão mutante como o atual.

Dentro desta realidade, novas técnicas de ensino podem ser utilizadas e incorporadas às já existentes para que os objetivos propostos pela educação superior continuem sendo alcançados. Não é uma questão de negar o que já existe e muito menos de desconsiderá-lo, é mais uma questão de utilizar a experiência adquirida em favor das necessidades que surgem.

Nesse contexto, a Teoria das Inteligências Múltiplas, utilizada em conjunto com as técnicas existentes no processo de ensino e aprendizagem poderá auxiliar na melhor preparação do profissional como um todo, tanto tecnicamente como no desenvolvimento de habilidades como trabalhar, cooperativa e colaborativamente, em equipe, falar em público, apresentar seminários, redigir relatórios, sempre tendo em mente as possibilidades e necessidades do ambiente profissional e sócio-econômico em que o indivíduo está inserido.

\subsection{OBJETIVO DO TRABALHO}

Este trabalho propõe-se a discutir, a partir do referencial teórico das Inteligências Múltiplas, como incrementar o uso das estratégias de ensino aula expositiva, seminários e projeto - utilizadas no Ensino de Engenharia, 
com o objetivo de revitalizar a aprendizagem e a formação do engenheiro visando a sua assimilação pelo mercado de trabalho.

\subsection{JUSTIFICATIVA}

A educação hoje é uma prioridade política e social em todo os países. O processo, as técnicas e os meios de ensino e aprendizagem, vêm sofrendo grandes alterações para continuar garantindo sua eficiência (MELLO, 1997). Várias mudanças ocorreram devido a pesquisas realizadas que, aos poucos, foram alterando o foco de uma educação centrada no ensino, que desconsiderava qualquer diferença e preferência individual de aprendizagem, para uma postura mais flexível, tendo como objetivo o desenvolvimento individual e grupal de todos os envolvidos no processo.

Segundo RIBEIRO (1998), lembrar sempre que diferentes pessoas têm diferentes interesses e preferências de como aprender, fará os educadores entenderem melhor o processo de aprendizagem do indivíduo. Isso ocorre, muitas vezes, não porque o educador "quer" ou porque ele executou seu trabalho com maestria, e, sim, porque o aprendiz desenvolveu-se o suficiente para a assimilação de tais conteúdos.

No contexto de diferentes preferências durante 0 processo educacional, a Teoria das Inteligências Múltiplas tem o potencial de expandir as diretivas curriculares a fim de visualizar todas as necessidades educacionais e pessoais de uma maneira holística, e trabalhar condutas e posturas além da habilidade técnica proposta pelos cursos de graduação (STANLEY, 1997; GARDNER, 1998).

A Teoria das Inteligências Múltiplas em conjunto com as estratégias de ensino existentes (seminários, projetos, aulas expositivas) facilitará o trabalho do educador, proporcionando uma maior flexibilidade e uma maior possibilidade de, efetivamente, desenvolver trabalhos de interdisciplinaridade, promovendo um desenvolvimento holístico do indivíduo envolvido nesse processo. 
A Teoria das Inteligências Múltiplas vem trazendo uma nova dimensão ao entendimento de como adultos aprendem e conquistam seus objetivos pessoais, sociais e profissionais (SHELTON, 2000).

O processo de aprendizagem é natural, todos aprendem o tempo todo no dia a dia e quanto mais perto desta sensação de aquisição de conhecimento natural e confortável a prática nos meios acadêmicos conseguir chegar, maior será a possibilidade de sucesso no quesito - criação de profissionais competentes e atuantes no mercado atual, que considera habilidades complementares às técnicas.

\subsection{ESTRUTURAÇÃO DO TRABALHO}

Esta dissertação está dividida em 8 capítulos:

Capítulo 1: A partir de uma introdução das mudanças ocorridas com a globalização e suas implicações no mercado de atuação e no processo educacional. Este capítulo visa esclarecer a contribuição desse trabalho ao ensino de engenharia a partir do esclarecimento do objetivo, preposições e problemas que o justifica;

Capítulo 2: Esse capítulo comenta sobre a globalização e suas implicações no processo educacional como força motivadora para quebra de paradigma e no estabelecimento de um perfil profissional mais adaptado à realidade mercadológica atual;

Capítulo 3: Para que a atividade acadêmica seja executada com maestria, o processo de planejamento, a definição de objetivos, as escolhas da melhor estratégia a ser utilizada e da avaliação a ser aplicada são fundamentais. Nesse capítulo, as fases que antecedem a atividade de ensino de sala de aula são definidas juntamente com sua importância dentro do processo educacional;

Capítulo 4: Nesse capítulo as diversas estratégias que podem ser utilizadas durante o processo de ensino e aprendizagem são identificadas, 
classificadas e as principais características pertencentes a cada uma delas são esclarecidas;

Capítulo 5: O objetivo desse capítulo é fazer uma retrospectiva histórica sobre inteligência, sua implicação e a concepção de sua pluralidade da inteligência dentro da mudança do paradigma educacional;

Capítulo 6: Descreve os princípios básicos da Teoria das Inteligências Múltipla proposta por Howard Gardner, seus diferentes tipos e as características próprias de cada uma delas;

Capítulo 7: A partir dos assuntos abordados nos capítulos anteriores, esclarecer como as estratégias - aula expositiva, projeto e seminários podem ser incrementadas, objetivando desenvolver algumas características específicas necessárias para a perfeita adaptação do profissional no mercado de trabalho utilizando como suporte a Teoria das Inteligências Múltiplas;

Capítulo 8: Esse capítulo aponta as considerações finais do trabalho. 


\section{O MODELO DE ENSINO E AS TENDÊNCIAS}

\section{DE MERCADO}

Sempre houve consenso quanto à necessidade da adaptação do sistema educacional ao momento que atravessa uma sociedade e em relação à mudança sócio-econômica mundial. Essa adaptação do modelo educacional vigente é justificada por características que são incorporadas à sociedade e ao mercado de trabalho. Como as instituições de ensino de $3^{\circ}$ grau tornaram-se o meio formal de prover a sociedade com mão-de-obra capaz de satisfazê-la, essas adaptações tornam-se fundamentais para o progresso contínuo do desenvolvimento do processo de ensino e aprendizagem.

A preocupação com o constante desenvolvimento profissional e pessoal, com a finalidade de adaptação ao campo de atuação profissional, tem suas justificativas em processos históricos. A educação tem sido um privilégio de poucos que pertencem às elites, uma minoria de grande influência nas sociedades. Por meio de tutores, responsáveis pelo processo de transmissão do conhecimento, recebiam-no na medida do necessário para que a função exercida na sociedade fosse desempenhada de uma forma eficiente. 
No período pós-revolução industrial, um número maior de pessoas passou a fazer parte do processo de construção da sociedade, em modernização. A educação assume uma função técnica qualitativa de aperfeiçoamento de mão-de-obra, e quantitativa, oferecida às classes populares como opção de preparação de mão-de-obra especializada para suprir a necessidade de produção e participação do processo de mudança e de expansão capitalista que a sociedade atravessava (MORAN,1997).

Posteriormente, na década de 70 e início dos anos 80 , a crise do petróleo provocou recessão e inflação nos países do Primeiro Mundo e novamente, métodos e técnicas de produção tiveram que ser adaptados, utilizando a automação, a robotização e terceirização como recursos para aumentar a produtividade e reduzir a necessidade de mão-de-obra direta (JANNI, 1996).

Segundo MARTINS (1990), todas as mudanças significativas mercadológicas tiveram sua implicação direta e provocaram uma adaptação no processo educacional. O capitalismo, que levou a sociedade a interpretar a educação como um investimento econômico que deveria ser organizado de modo a ter um desempenho eficiente, para que o retorno deste investimento fosse justificado em termos de rentabilidade financeira, foi muito significativo na década de 80 junto com a incorporação da tecnologia no processo produtivo.

A contínua incorporação da tecnologia no processo produtivo e a exigência por uma mão-de-obra específica exigiram investimentos financeiros consideráveis em diversas áreas. A educação e passaria a ser incorporada ao mercado de trabalho, tanto como uma ferramenta auxiliando a produção, quanto um dos veículos utilizado para preparar a mão de obra necessária. 


\subsection{O Processo de Globalização e a Adaptação do Processo de Ensino - Aprendizagem}

Com a inserção da tecnologia, o meio de produção era melhorado e com isso barreiras mercantis foram quebradas, desencadeando um processo que posteriormente foi chamado de Globalização. $O$ termo globalização ocupou e continua ocupando um lugar de destaque nas mesas de discussões em vários círculos políticos, acadêmicos, eventos empresariais e, especialmente na mídia.

O termo Globalização define um conjunto de transformações de ordem política e econômica mundial que começou a ocorrer nas últimas décadas e que provoca alteração em todo processo sócio-econômicoeducacional de todas as nações (MAGNOLLI ,1983).

CHENAIS (1996), especialista em economia da inovação tecnológica, diz que o adjetivo "global" emergiu no começo dos anos 80 nas grandes escolas americanas de administração de empresas, as célebres "Business Management Schools" de Harvard, Columbia e Stanford e foi popularizado nas obras e artigos de consultores de estratégia e marketing.

O termo surgiu nos EUA, mas o estímulo efetivo à globalização, veio dos japoneses que provocaram, com seu desempenho produtivo e mercadológico, uma maior organização na reformulação de estratégias internacionais, constatando que, com o advento da tecnologia e do processo de globalização, empresas não teriam nacionalidade e poderiam estar em qualquer lugar do mundo produzindo diferentes produtos onde se pudesse gerar lucro (JANNI, 1996).

O processo de "quebra de barreiras mercantis" provocou uma reação em cadeia onde a globalização desencadeou uma competitividade industrial maior de produtos e serviços, alterando o quadro do mercado de atuação. De um mercado regional, onde os produtos circulavam em áreas bastante restritas, passa-se a um mercado onde imperam confrontos entre produtos de ampla circulação, onde as noções de distância territorial são praticamente 
aniquiladas. Dentro deste panorama, é impossível não haver uma mudança do perfil profissional das pessoas que atuam e atuarão neste contexto mercadológico (MORGAN et al., 1998).

Um dos pontos centrais de toda mudança é a integração dos mercados numa "aldeia-global", explorada pelas grandes corporações internacionais, que fazem com que o processo ultrapasse os limite da economia e comecem a desencadear uma pressão considerável, e de certa forma generalizada de homogeneização cultural e educacional entre os países.

Como não é possível desvincular a atividade educacional do contexto histórico pelo qual atravessa uma sociedade, é de se associar que essas mudanças tenham suas conseqüências diretas dentro do processo de ensino e aprendizagem das Instituições de Ensino. Não há desenvolvimento sem educação. Neste contexto da globalização, as instituições de ensino superior possuem uma responsabilidade grande na formação de profissionais que deverão atuar nesta sociedade.

Segundo MASETTO (1990), as Instituições de Ensino Superior são as principais responsáveis pelo desenvolvimento de habilidades profissionais e empregabilidade do povo de um país. A educação faz parte de um processo de ação que deve ser capaz de produzir mudanças comportamentais e técnicas para que pessoas envolvidas possam lidar com este novo mercado de uma forma interativa.

A educação superior tem como ponto referencial satisfazer as necessidades de conhecimento e expectativas profissionais do homem, facilitando sua inserção e atuação no mercado de trabalho, portanto, se há uma mudança no perfil mercadológico vigente, não há como negligenciá-las, por muito tempo, dentro do processo educacional (SWIFT,1977).

A dinamicidade do mercado profissional desencadeia um processo de aperfeiçoamento técnico e pessoal dos indivíduos que pertencem as Instituições de Ensino Superior, de uma forma coerente, principalmente 
porque elas estão relacionadas a toda uma estrutura formal do mercado profissional e das relações sócios econômicas.

Nesse ambiente, o processo educacional sofre pressão do mercado e do contexto de globalização durante a formação profissional do indivíduo, e deve exercer uma pressão na direção contrária para que ocorra a absorção do profissional formado pelo ambiente gerando novas demandas. (FIGURA 2.1).

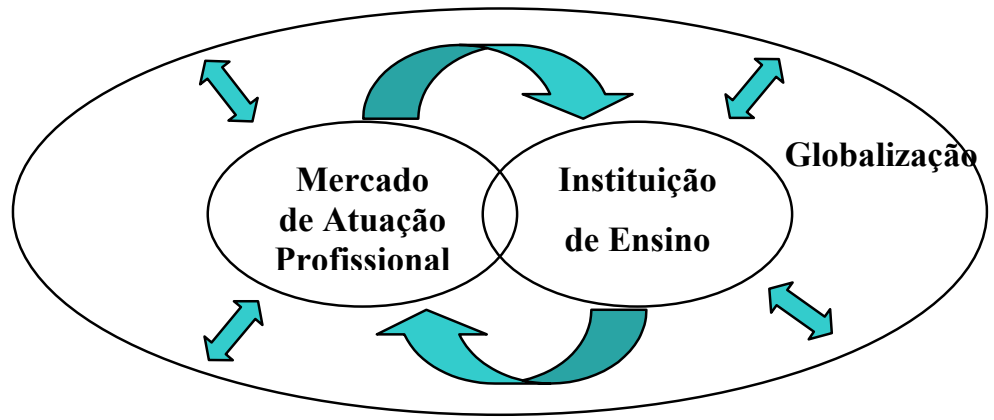

FIGURA 2.1 - O processo de globalização e sua co-relação com o ensino e mercado: o processo de globalização interferindo e sofrendo interferência no mercado de atuação profissional e nas Instituições de Ensino Superior.

Este processo de satisfazer o mercado, a sociedade, assim com as expectativas pessoais de todos envolvidos no processo de formação profissional direciona o ensino e aprendizagem a uma dicotomia, onde a preocupação que o educador deve ter em identificar as necessidades e expectativas do educando e da sociedade chega a ser fundamental para a efetividade do sistema educacional e social vigente (MARTINS, 1990).

\subsubsection{A educação no contexto socio-econômico}

Segundo MARTINS (1990), o significado da palavra "ensinar", tem como sinônimos - guiar, dirigir, mostrar - verbos que apontam para o professor como sendo o agente principal do processo de ensino; quanto à palavra "aprender", encontra-se sinônimos como - adaptar-se às mudanças, 
descobrir significados - situações que apontam para o aprendiz como sendo agente principal e responsável pela sua aprendizagem.

Estas duas posições, hoje indissociáveis, tiveram, em momentos diferentes, suas contribuições individuais.

O processo educacional, durante muito tempo, teve como foco o papel do educador - ensino, que foi reforçado pela postura dos próprios alunos que ingressam com expectativas passivas de "serem ensinados" pelos "grandes mestres e especialistas" nos assuntos relacionados à profissão que escolheram, dando pouquíssima importância na subjetividade da aprendizagem envolvida (ABREU, 1975).

Com o passar do tempo, com os alunos participando ativamente do processo de ensino, houve a constatação que o processo educacional é de troca, onde "A interação entre quem ensina e quem aprende é uma expressiva e significativa realidade que faz com que o comportamento de um sirva de estímulo ao comportamento do outro. Essa interação entre professor e aluno, na sala de aula, se dá exatamente como conseqüência dos procedimentos planejados pelo professor e que proporcionam a realização das modificações pretendidas no comportamento do aluno" (TURRA,1982 p. 27).

A partir do momento em que o aluno, efetivamente, passa a dar sua colaboração na socialização da informação e assume a co-responsabilidade pelo seu desenvolvimento pessoal e profissional, há uma mudança significativa do foco somente do ensino, ou somente da aprendizagem, para o de "ensino e aprendizagem", incluindo neste contexto do processo educacional, além das necessidades já existentes, uma nova variável, o campo de atuação profissional. (FIGURA 1.4). 
a)

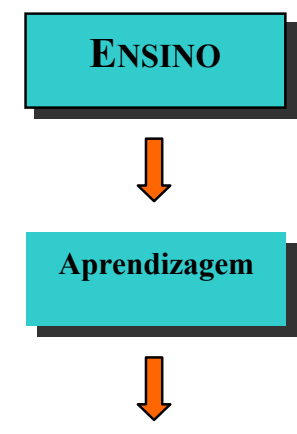

b)

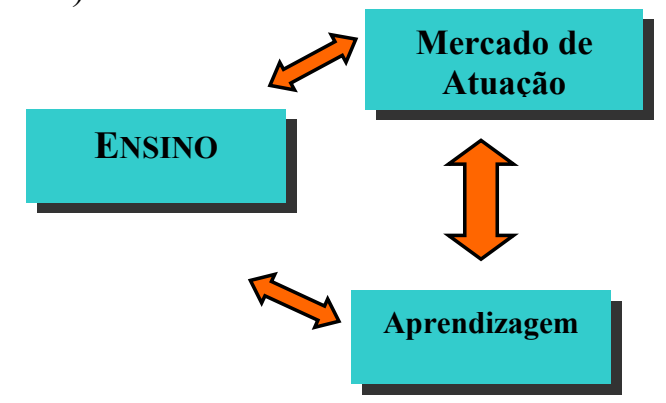

Mercado de Atuação

FIGURA 2.2 - Mudança do foco do ensino: a) A ênfase no processo de ensino com a aprendizagem e o mercado norteando de forma discreta a aprendizagem que estava "diretamente" focada no processo de ensinar. b) O mercado de atuação e o processo de aprendizagem, trabalhando de forma integrada ao processo de educação.

O mercado de atuação sempre teve uma participação no processo de ensino, mas de uma forma discreta, direcional, hoje ele atua de uma forma incisiva, uma vez que há uma troca de informação intensa com a finalidade específica de preparação de mão de obra muito mais especializada do que antes.

O mercado atual exige profissionais com características técnicas e pessoais diferenciadas. As instituições procuram preparar, cada vez melhor e este profissional, superando, muitas vezes, as expectativas do mercado, gerando uma nova demanda. Toda vez que as pessoas adaptam-se à realidade existente, fazem surgir novas áreas de atuação.

\subsection{O Mercado de Trabalho e o Ensino de Engenharia}

Segundo WENK (1998), a engenharia já chegou a ser considerada uma arte mais do que uma ciência, definição aceita a partir de trabalhos de inventores e empresários que ao desenvolver novos produtos e materiais a 
serem utilizados, atribuíam, relativamente, pouca atenção às bases científicas que sustentavam seus conhecimentos.

No começo do século $X X$, as bases científicas da engenharia ganharam importância com o desenvolvimento das ciências ligadas à química e à eletricidade, mas foi depois da Segunda Guerra Mundial, com o começo da "Guerra Fria" e o desenvolvimento econômico pós-guerra dos EUA, que se criou uma demanda por engenheiros, produtos e serviços desenvolvidos por eles.

No Brasil, a Engenharia nasceu e se desenvolveu simultaneamente ao processo de industrialização com o passar do tempo o desenvolvimento de produtos e prestação de serviços, termos como qualidade, satisfação do cliente, etc, foram sistematicamente acopladas aos estudos realizados para a melhoria profissional. A qualidade é uma questão que muito interessa à Engenharia, sobretudo, nos ambientes industriais e de serviços.

Não se aplica controle de qualidade ao fim da linha de produção, ao contrário, investe-se na organização, implementando condições de forma sistemática e competente ao longo de todo o processo. A preocupação com a qualidade do processo de formação do engenheiro, surgiu como meio de se assegurar qualidade do serviço e do produto desenvolvido por eles (COLENCI,1996).

Hoje, devido a conceitos firmados de que a qualidade do todo é garantida pela qualidade das partes que o compõem, a qualidade que envolve o desempenho do indivíduo na profissão é considerada associada ao processo de formação. Qualquer forma de retrabalho ou rejeição, seja ela de que nível for, por si só é onerosa e descabida dentro de uma linha de produção. Seguindo este mesmo raciocínio, também não é aceitável que o profissional formado não seja absorvido pelo mercado, principalmente se constatado que isso é devido a uma falha na sua formação.

A idéia de melhoria de todo o processo educacional também se aplica à pós-graduação. Assim, os alunos, ao saírem dos cursos de graduação e almejando por melhores colocações no mercado de trabalho, procuram por 
cursos de pós-graduação. Outra situação que ocorre é a busca por mais conhecimento e melhor preparação por meios das diversas e diferentes modalidades de cursos de pós-graduação.

Começam a surgir, então, as primeiras dificuldades de condutas e habilidades. Em um primeiro momento, o pós-graduando é orientado para a escrita de projetos, desencadeando-se um processo de desconforto, bem como no momento da realização de seminários, de estudos de caso ou do trabalho em equipe, dentre outros.

Junto às técnicas adquiridas na graduação, será necessário utilizar "todo" o conhecimento adquirido através de livros, jornais, revistas, conversas, maturidade, etc, para realizar os trabalhos solicitados.

Com a sensação de desconforto, por não se ter aprendido a realizar estas atividades, inicia-se um processo de questionamento, próprio da imaturidade profissional, sobre o quão importante foi "tudo" que foi estudado no período de graduação. Já que nunca lhe ensinaram a fazer "isto" ou "aquilo" os alunos começam a perceber como determinados conhecimentos também são fundamentais para o sucesso como profissional.

Nesse contexto, inicia-se ainda um processo de conscientização tardia de que os conhecimentos técnicos, a postura profissional, a capacidade de raciocínio crítico e a disciplina são importantes e necessários.

No âmbito empresarial, a mesma cena se repete só que este processo de conscientização e aprimoramento de capacidades são realizados e desenvolvidos durantes os programas de trainees.

É alocado muito tempo, dentro desses programas, para o aprimoramento de posturas e capacidades necessárias para a realização, com qualidade, dos serviços a serem prestados pelo profissional à empresa.

Esta qualidade no desempenho das atividades, está relacionada a algumas características que vão além da capacitação técnica; estando mais ligadas a posturas e desempenhos profissionais, ou seja, no "como" é desempenhada a função - (apresentação de projeto, conhecimento 
organizacional, posturas éticas, pesquisas e conhecimentos de tópicos relacionados, raciocínio críticos, etc).

Segundo ERST (1996), no atual momento socioeconômico, apenas a educação formal técnica não garante mais o posicionamento e a inserção do profissional no mercado de trabalho. O grande diferencial recai nas características pessoais e de atitudes agregadas ao perfil teórico/técnico. É necessário olhar o processo de ensino/aprendizagem de uma forma holística. Especificamente na profissão de engenheiro, é conveniente analisar a responsabilidade desse profissional dentro do contexto mercadológico em que está inserido e a partir dessa análise, desenvolverlhe a capacidade de desenvolver habilidades específicas que o ajudarão a ingressar e a permanecer no mercado profissional de forma competitiva.

\subsection{Tendência de Mercado e Evolução do Processo de Ensino e Aprendizagem}

No atual mercado de trabalho, a capacidade técnica já deixou de ser a única necessária. Há necessidade de profissionais que sejam capazes de trabalhar em equipes reais e virtuais, que entendam o funcionamento organizacional, que conheçam e pense, de forma crítica, todo o contexto socio-econômico da empresa e dessa empresa em relação ao mercado a que pertence, dele próprio em relação à empresa a que está ligada e às condições do mercado de atuação a que pertencem.

MORGAN et al. (1998), afirma que as organizações exigem trabalhadores que possuam habilidades analíticas associadas ao conceito de criatividade, liderança e relacionamentos sociais e profissionais, ou seja, aquilo que a sociedade do conhecimento e o planejamento educacional já coloca como prioridade: o desenvolvimento técnico, cognitivo e social do indivíduo, de acordo com a necessidade temporal do mercado profissional e social. 
Dentre todas as características técnicas e pessoais necessárias aos profissionais de engenharia propostas pelas diretrizes curriculares dos cursos de engenharia, muitas são similares para as diversas áreas do conhecimento. (TABELA 2.1).

TABELA 2.1: Características pessoais e técnicas necessárias ao profissional que deseja atuar no mercado de trabalho atual.

\begin{tabular}{|c|c|}
\hline \multicolumn{2}{|c|}{ CARACTERÍSTICAS } \\
\hline TÉCNICAS & PESSOAIS \\
\hline $\begin{array}{l}\text { Capacidade de reconhecer os } \\
\text { problemas e solucioná-los em } \\
\text { diversas áreas. }\end{array}$ & $\begin{array}{l}\text { Ampla cultura e curiosidade por novos } \\
\text { conhecimentos }\end{array}$ \\
\hline $\begin{array}{l}\text { Aplicar conhecimentos matemáticos, } \\
\text { científicos, tecnológicos e } \\
\text { instrumentais à engenharia }\end{array}$ & Bom relacionamento humano. \\
\hline Domínio de técnicas Computacionais & $\begin{array}{l}\text { Avaliar criticamente ordens de } \\
\text { grandeza e significância de resultados }\end{array}$ \\
\hline $\begin{array}{l}\text { Conhecimento de legislação } \\
\text { pertinente }\end{array}$ & $\begin{array}{l}\text { Compreender e aplicar ética e } \\
\text { responsabilidades profissional }\end{array}$ \\
\hline $\begin{array}{l}\text { Avaliar a viabilidade técnica, } \\
\text { econômica e social dos projetos de } \\
\text { engenharia. }\end{array}$ & Responsabilidade Social e Ambiental \\
\hline $\begin{array}{l}\text { Capacidade de trabalhar em equipes } \\
\text { multidisciplinares }\end{array}$ & Versatilidade e Criatividade \\
\hline Domínio de língua estrangeira & Senso de cidadania \\
\hline $\begin{array}{l}\text { Compreensão dos problemas } \\
\text { administrativos, sócio-econômicos e } \\
\text { do meio ambiente }\end{array}$ & $\begin{array}{l}\text { Autoconfiança nas suas posturas } \\
\text { profissionais }\end{array}$ \\
\hline $\begin{array}{l}\text { Capacidade comunicar suas idéias e } \\
\text { defender seus projetos } \\
\text { coerentemente }\end{array}$ & $\begin{array}{l}\text { Alto sentido ético, social e de } \\
\text { responsabilidade profissional }\end{array}$ \\
\hline Autodidatismo & $\begin{array}{l}\text { Mentalidade aberta e atitude positiva } \\
\text { diante da vida }\end{array}$ \\
\hline
\end{tabular}


Tendo em vista as características pretendidas para o novo profissional da área de Engenharia e as novas perspectivas de trabalho, o educador deverá repensar sua prática didática, distanciando-se das imposições das práticas pedagógicas tradicionais, uma vez que a dimensão do ensino atual, em muitas situações, restringe os potenciais por uma abordagem limitada de conteúdos, sem sequer relacioná-los, objetivamente, ao perfil do profissional a ser formado.

O mercado atual, devido a sua característica temporal, solicita um profissional disposto a se desenvolver em qualquer área afim à sua formação, impondo uma conduta flexível de formação e de aprendizagem.

PETTERSON (1998), diretor executivo do Accreditation Board for Engnineering and Technology, diz, em seu artigo "Engineering Criteria 2000: A Bold New Change Agent" (Critérios de Engenharia 2000: Um diferenciado agente de mudanças), que a prática da Engenharia mudou dramática e irreversivelmente, impulsionada por algumas características:

$\checkmark$ Crescente competição e, por conseguinte, a reestruturação industrial;

$\checkmark$ Mudança nas principais áreas de atuação do engenheiro, migrando para os empreendimentos privados; e

$\checkmark$ Explosão da "tecnologia da informação".

Nesse contexto, para suprir o mercado com profissionais capazes de atuar nesta realidade, as universidades e responsáveis formais pelo desenvolvimento deste profissional devem ficar atentas para o modo com este indivíduo é formado. Isso implica numa reavaliação e alteração do processo de ensino e aprendizagem e até mesmo das estruturas curriculares vigentes.

MORGAN et al. (1998) atribui a necessidade de adaptações didáticas/ pedagógicas, por parte dos professores, como um dos meios necessários para se atingir o sucesso do processo de formação do profissional durante a graduação a eventos como: 
1) Velocidade da eVolução da TeCnologia pois a tecnologia evolui tão rapidamente que alguns dos conhecimentos de Engenharia se tornam obsoletos em um curto espaço de tempo, como resposta, estudantes e profissionais, precisam "reaprender" num curto espaço de tempo, como atuar em suas profissões, sendo necessário o desenvolvimento consciente da capacidade de aprendizagem constante (aprender a aprender);

2) MAIS CONHECIMENTO - MAIOR COMPLEXIDADE já que cada vez mais materiais são melhorados com o uso da tecnologia, levando a uma necessidade de assimilação de conceitos mais complexos e mais profundos. Desta forma, "aprender a aprender" é fundamental para se adaptar às mudanças provocadas pela inserção da tecnologia nesse contexto e da assimilação de novos conhecimentos; assim como a capacidade de integração desses em complementação a conceitos já existentes e conhecidos;

3) MUdAnÇA do FOCO PARA PRESTAÇÃo de SERVIços dado que nos últimos 20 anos, houve uma mudança no foco das áreas de atuação do engenheiro. Cada vez mais pessoas migram de grandes empresas para pequenas e médias com a filosofia de prestação de serviços. Isso força os profissionais a se capacitarem de forma diferenciada e agregar, ao seu conhecimento técnico, noções de planejamento, finanças, administração, manufaturas, demanda de mercado, compartilhamento de informações, trabalho em parcerias, etc;

4) Globalização (DE PROdutos E SerVIÇOS) pois com o advento da globalização houve uma crescente competição assim como a criação de oportunidades novas. Com intuito de colaboração internacional, as barreiras científicas mundiais foram minimizadas, provocando uma mudança no contexto de atuação profissional.

5) Parcerias entre Universidades e Mercado dado que a tendência de fusão entre instituições de ensino e mercado de 
trabalho, que faz com que o ensino se torne mais eficiente e flexível de acordo com a proposta de cada instituição e da regionalidade a que pertence. A criação das parcerias vem ao encontro da necessidade de que, quanto mais próximo estiver o profissional do mercado em que atuará, durante a construção do seu conhecimento e perfil profissional, mais eficiente será sua contribuição/intervenção para a melhoria do panorama sócio-econômico-cultural.

6) "INTERAÇÃO" DA ENGENHARIA COM OUTRAS ÁREAS visto que cada vez mais cresce a parceria entre profissionais de Engenharia e de outras profissões como Física, Medicina, etc., comprovado pelo avanço de áreas como Biologia Molecular, Biomedicina, Biomateriais, Instrumentos Cirúrgicos, dentre outros, trazendo à consciência a interrelação que a Engenharia possui com diferentes áreas de conhecimento específico. Este fator possibilita ao profissional escolher e criar sua área de atuação de acordo com suas habilidades e características regionais mercadológicas.

Estudos como os de ALMEIDA (1996) e FAGUNDES (1997) comprovam a necessidade da adaptação do modelo educacional vigente à realidade ao qual atravessa uma sociedade e a necessidade de flexibilidade e qualificação pessoal. Esses estudos reforçam um paradigma que promove aprendizagem em complementação ao ensino, que coloca o controle e uma parte da responsabilidade do sucesso desse processo de formação nas mãos do aprendiz, auxiliando ao educador a compreender melhor todo processo de construção de conhecimento das pessoas envolvidas.

MARTINS (1990) e MACHADO (1995) afirmam que é no embate reflexivo da formação e atuação que o docente desenvolve uma didática prática e passível de caminhar rumo a uma pedagogia alternativa, referindose às mudanças no ensino tradicional como necessárias.

A partir de características pontuadas por MORGAN et al. (1998): velocidade da evolução da Tecnologia, conseqüentemente mais informação, mais complexidade, maior conhecimento; Mudança do foco para prestação 
de Serviços, Processo de Globalização, Parcerias entre Universidades e Mercado, "Interação" da Engenharia com outras áreas, etc, há uma tendência e necessidade de agregar aos currículos dos cursos de graduação conhecimentos de:

$\checkmark$ Tecnologia de informação: As instituições de ensino devem analisar esta característica por dois focos: 1) como um meio instrutivo e facilitador de aprendizagem e 2) como um novo mercado de atuação com grande perspectivas e interligado a diversas áreas;

$\checkmark$ Preocupações sociais, políticas e de meio ambiente: aumento das expectativas e de conscientização dos assuntos relacionados, desenvolvendo capacidade de análise, levando em conta a diversidade social, política, e fatores ambientais relacionados à atividade profissional;

$\checkmark$ Habilidades de trabalho em grupo e de Comunicação: Estas talvez sejam as características predominantemente solicitadas pelo mercado. O processo de globalização, socialização do conhecimento e tecnológico possibilitou que equipes fossem formadas com padrões e disciplinas diferentes das existentes, com isso o processo de comunicação entre elas também sofreu mudanças. Lidar de forma tranqüila nesse ambiente, muitas vezes virtual, é dominar a habilidade de trabalhar e comunicar-se com pessoas e de formas diferentes;

$\checkmark$ Conhecimentos das áreas de Administração e Finanças: Aos profissionais atuantes no mercado atual, é solicitada habilidade de gestão, ou seja planejamento, controle e avaliação de processos e serviços, e não há como realizar essa função efetiva e eficientemente sem conhecimentos das áreas relacionadas;

$\checkmark$ Habilidade de auto-aprendizagem: devido a todo processo de transformação agregada à velocidade dos acontecimentos, a capacidade de auto-aprendizagem chega a ser fundamental para qualquer pessoa que desempenhe alguma função. A velocidade com que conhecimentos novos surgem e anteriores são melhores 
definidos é alta em comparação com o tempo que poderiam ser gastos para a aquisição formal deles através dos meios formais (cursos) e chega a ser oneroso.

A estas características podem ser acrescentadas - ética e cidadania, que devem ser levadas em consideração pelo educador durante a construção do conhecimento técnico e principalmente durante o planejamento, a definição dos objetivos, e a prática em sala de aula, garantindo o sucesso do processo de formação profissional. 


\section{PROCESSO TRADICIONAL DE PLANEJAMENTO DO ENSINO E DA APRENDIZAGEM}

O processo de ensino e aprendizagem é uma ação intencional e sistemática que, como todo processo, precisa ser planejado e controlado adequadamente em todas as fases de execução (MASETTO, 1990).

Para que o planejamento seja efetivo ele deve englobar todas as variáveis que participam, direta ou indiretamente, do processo de ensino e aprendizagem - recursos humanos e materiais disponíveis, objetivo a ser alcançado tanto pela disciplina como por um conteúdo específico, desenvolvimento de habilidades pessoais pré-existentes, relevância deste assunto na formação profissional do indivíduo, dentre outras. Por se tratar de uma fase que servirá de direcionamento para a execução é de grande relevância sua realização.

Segundo MASETTO (1990) e MARTINS (1990), realizar um planejamento significa elaborar um roteiro, um sistema de referência a ser seguido e pode ser dividido em 3 grandes etapas:

a) 1- ETAPA: Escolha dos objetivos - hierarquização de prioridade de acordo com o conteúdo a ser aplicado;

b) 2a ETAPA: Programa de ação - definição das estratégias para que o objetivo seja atingido; 
c) 3a ETAPA: Avaliação dos objetivos e do programa - ações e decisões constantemente sendo reavaliadas e modificadas, flexibilidade.

Toda vez que temos que lidar com um número relativamente grande de variáveis com um objetivo comum se faz necessário um planejamento detalhado.

O planejamento de ensino é a previsão de todas as fases do trabalho que será realizada pelo professor e pelo aluno visando a um melhor aproveitamento do tempo disponível em relação ao conteúdo a ser abordado.

Segundo DAVIES (1979), o planejamento é um processo dinâmico que prevê uma meta a ser atingida e as formas de atingi-las, visando a atender, dentro deste contexto, expectativas pessoais e sociais individuais. É um processo decisório que resulta em um plano de ação, dispostas de forma lógica e coerente possibilitando o acréscimo ou retirada de determinado conteúdo. Durante o desenvolvimento do planejamento, a avaliação, como meio de direcionamento do processo, deve ocupar um lugar de destaque.

O planejamento nas instituições de ensino superior torna-se fundamental por possuir um público diferenciado, com alguns objetivos comuns e com uma postura inicial propensa a somente receber informações para construção do seu conhecimento. Este talvez seja um dos fatores pelos quais, durante tanto tempo, todo trabalho de planejamento foi o foco primordial do ensino.

Os professores planejavam seus conteúdos preocupados de como ensinariam ou explicariam determinados assuntos e poucos percebiam a necessidade de privilegiar a aprendizagem efetiva durante o processo de planejamento

MASETTO (1990, p.6) afirma " que toda e qualquer instituição de ensino, qualquer que seja seu nível, justamente porque existe em função do aluno (pessoa, membro de sua sociedade, profissional) e da sociedade na 
qual se insere, deverá privilegiar a aprendizagem de seus alunos sobre o ensino de seus professores".

Este aprendizado está diretamente ligado a "o que" o aluno deve aprender para ingressar no mercado de trabalho e, se necessário, criar sua própria área de atuação a partir do seu perfil profissional.

O profissional necessário no mercado de hoje pode não ser o mesmo necessário ao mercado daqui a cinco anos, o que justificaria o desenvolvimento de algumas habilidades específica no educando e isso só poderá ser alcançado eficientemente através de um planejamento didático e flexível.

MARTINS (1990) afirma que o planejamento é um sistema elaborado e organizado que visa orientar a ação docente e discente, sujeito a modificações, portanto deve ser flexível, uma vez que é elaborada, geralmente, de forma genérica, não levando em consideração o momento do ensino.

A partir dos estudos realizados por MARTINS (1990), MASETTO (1990) e FAGUNDES (1997), os elementos essenciais na estruturação de um planejamento são:

$\checkmark$ Objetivo: 0 que se pretende alcançar com o ensino e sua hierarquização de prioridade. Para melhor direcionar o objetivo, questões como: " Para que ensinar isso" devem ser respondidas.

$\checkmark$ Conteúdo: baseado no objetivo verificar "o que ensinar" para que sejam alcançados eficientemente.

$\checkmark$ Estratégia: métodos, técnicas e recursos a serem utilizado para que o conteúdo seja trabalhado eficientemente, "Como ensinar".

$\checkmark$ Avaliação: métodos utilizados para verificação da eficácia do que foi realizado, do que foi planejado, e em um segundo momento, se aquilo foi relevante para o bom desempenho pessoal e profissional do indivíduo. 
Existem outros elementos como ementa, cronograma de execução, bibliografia a ser utilizada, que também têm função de nortear a ação do docente e do discente; e, que deveriam ser considerados durante $o$ planejamento.

\section{1 Plano de Ensino}

O plano de ensino faz parte do planejamento, tem a função de apresentar, sob forma organizada, um conjunto de decisões tomadas pelo professor em relação á disciplina a lecionar. É feito, antes do curso iniciar efetivamente; não tem, porém, uma linha fechada, inflexível; pelo contrário, deve ir se adaptando á medida que a interação com os alunos vai ocorrendo, e o feedback constante indica formas alternativas e mais eficientes de se atingir o objetivo proposto (MASETTO, 1990).

Para realizar seu planejamento e criar seu próprio plano de ensino, o professor, no processo de ensino e aprendizagem tradicional - centrado no ensino, considerava o conteúdo como um ponto de partida.

Hoje, com o foco tanto no ensino quanto na aprendizagem, o planejamento, assim como a seleção do conteúdo a ser abordado, deve partir do propósito geral da disciplina para o conteúdo específico - da matéria propriamente dita, pois o conteúdo é algo dinâmico e, portanto, flexível e reorganizável (MASETTO, 1990). (FIGURA 3.1)

A seleção adequada do conteúdo para o efetivo direcionamento do planejamento requer um bom conhecimento dos objetivos gerais da disciplina a ser trabalhada, para permitir uma discriminação eficiente do que é mais relevante naquele momento (no sentido formativo) sem, contudo, esquecer da filosofia educacional e da proposta educacional da instituição em que se trabalha (no sentido qualitativo) a fim de delinear com precisão suas atividades (MASETTO,1990 e MARTINS, 1990). 
a)

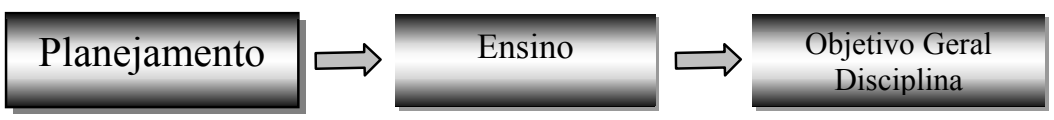

b)
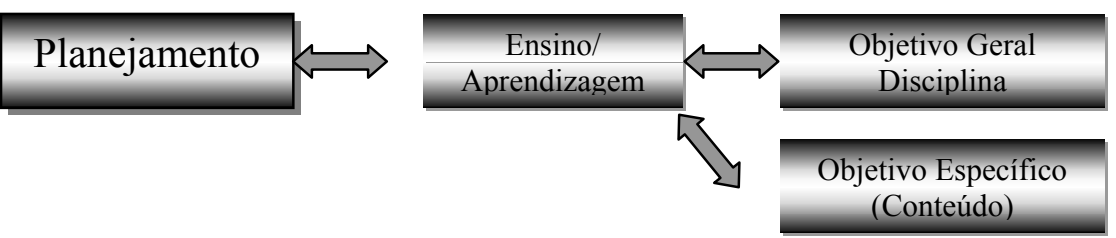

FIGURA 3.1. Plano de ensino tradicional e modificado - a) Todo plano de ação era realizado com foco no ensino e no objetivo geral da disciplina. (Ensino Tradicional) b) Todo plano de ação tem como foco o processo de ensino e aprendizagem e o objetivo geral e específico - disciplina e conteúdo, e sua constante avaliação serve como subsídios para um planejamento mais eficaz.

\subsection{Objetivos}

De posse do conhecimento da sociedade e do mercado vigente, o próximo passo será a definição dos objetivos a serem alcançados tanto pelas disciplinas quanto pelo conteúdo a ser abordado dentro da disciplina.

A definição desses objetivos, segundo MARTINS (1990), talvez seja uma das decisões mais complexas a ser feita por parte do educador, pois ele norteará todo o processo de planejamento, plano de ensino e estratégias a serem utilizadas.

Os objetivos a serem fixados podem ser classificados quanto à abrangência, de acordo com a necessidade e desejo do educador.

MASETTO,(1990) e KURI e GIORGETTI, (1994) classificaram em:

a) GeRAIS - dizem respeito ao espaço de tempo mais amplo em que a aprendizagem deverá ser realizada. Expressa o que se deseja alcançar através da disciplina a longo prazo, como parte integrante de um currículo específico. Designam processos mentais internos 
e são expressos utilizando-se verbos de ação não observáveis como conhecer, compreender, saber, perceber, criticar, dentre outros.

b) ESPECÍfICOS - dizem respeito ao espaço de tempo menor em que a aprendizagem deve ser realizada, são mais simples, concretos e alcançáveis em curto prazo. Direcionam para que o objetivo geral da disciplina no sentido qualitativo, a fim de delinear com precisão suas atividades.

Sem um plano de ação, quebra-se um elo importante do processo educacional, pois o ato de planejar e organizar a própria ação é o veículo disponível para agir, dentro da realidade de forma racional, com clareza, transparência, e agilidade a fim de garantir os objetivos.

Independentemente de qual objetivo esteja sendo descrito, ambos devem ser claros em relação ao "o que" deverá ser realizado e alcançado, levando em consideração as condições em que o processo de ensino/aprendizagem deverá ocorrer.

Segundo GOMES (1996), além de interagir com a globalidade dos assuntos que o cercam durante a realização do plano de ação, o educador deve preocupar-se com um conjunto de fatores educacionais que venham a interferir, de maneira positiva ou não, no aprendizado como: recursos disponíveis, metodologia* disponíveis, objetivos propostos, metas estipuladas, dentre outros.

Um bom educador é aquele que tem uma metodologia e dispõe de estratégias $^{* *}$ bem definidas. Isso só é possível através do total conhecimento das possibilidades materiais e contextuais, e ter consciência do que poderá e como poderá ser realizado implica em identificar as linhas de ação.

\footnotetext{
${ }^{*}$ Metodologia: estudo científico dos métodos

* Estratégia: arte de aplicar os meios disponíveis com vista à consecução de objetivos específicos. (MARTINS, 1990). Metodologia e estratégica serão usados como sinônimos significando a utilização dos recursos (métodos e meios) para alcançar objetivos específicos.
} 
É comum que educadores que ministram aulas nos cursos superiores, principalmente disciplinas de cunho técnico, tenham pouco ou nenhuma formação na área de educação, o que faz que utilizem muito pouco ou nada das estratégias de ensino disponíveis para atingir seus objetivos didáticos.

Não existe nenhum método específico a ser levado em consideração na elaboração dos objetivos disciplinares.

Dentre as várias opções MASETTO (1990), cita:

a) AdQUIRIR CONHECIMENTOS CONCRETOS - Em quase todos os problemas educacionais o aluno precisa adquirir determinado cabedal de conhecimentos: informações, fatos, conceitos, princípios, sua aplicação, teorias; interpretações, análises, estudos, hipóteses, pesquisas, debates, aspectos definidos, tópicos polêmicos, etc.

b) ADQUIRIR HABILIDADES - Referem-se a tudo o que o aluno deverá aprender para desenvolver suas capacidades intelectuais, afetivas, psíquicas e motoras: capacidade de organizar o estudo (aprender a aprender); capacidade de avaliar o próprio trabalho e o trabalho alheio; capacidade de formular uma hipótese, realizar uma pesquisa; coletar e organizar informações; utilizar os sentidos conforme a necessidade; dominar e usar movimentos e ação motora.

c) ATITUDES - Referem-se ao desenvolvimento comportamental dos alunos, diferentes daqueles que apresentava antes de cursar determinada disciplina. Por exemplo: curiosidade científica, perseverança no questionamento, responsabilidade quanta à aprendizagem, consciência crítica frente à realidade, à profissão, aos fatos, acontecimentos e às teorias, agente do seu processo de aprendizagem, solidariedade, competição, trabalho em equipe...

Todavia, observa MARQUES (1976, p. 51) "conhecimentos, habilidades e atitudes são trabalhados nas situações de aprendizagem ao mesmo tempo e estão sempre presentes, ainda que os co-participantes do processo ensino/aprendizagem não tenham muitas vezes uma clara consciência de como estas variáveis se comportam para configurar as 
aprendizagens resultantes. Em termos, porém, de planejamento e avaliação educacional, é conveniente manter um balanço entre objetivos que acentuam predominantemente a aprendizagem de conteúdos (conhecimentos), os que enfocam desempenhos ou ações que o aluno deverá vir a desenvolver (habilidades) e os que se destinam a operacionalizar o desenvolvimento de sentidos e emoções desejáveis, seja na área do relacionamento humano, seja como posicionamentos individuais específicos do perfil de determinada profissão (atitudes)".

BORDENAVE (1978) diz que o professor universitário deverá estar ciente de que muito maior do que a responsabilidade de criar profissionais competentes é a contribuição no desabrochar de personalidades autônomas e originais destes profissionais, capazes de repensar a realidade presente $\mathrm{e}$ forjar uma nova realidade. Esta responsabilidade é facilitada pela utilização de estratégias de ensino específicas direcionadas para um objetivo claro e definido.

A aula é o momento culminante de todo o trabalho planejado pelo educador, pois nela haverá a interação educador-educando no processo de ensino/aprendizagem através da prática da estratégia de ensino escolhida. O alcance ou não do objetivo proposto está diretamente ligado à estratégia utilizada, pois ela operacionalizará as decisões escolhidas.

\subsection{Estratégias}

Nos cursos de $3^{\circ}$ grau, enfatizou-se sempre a atividade de pesquisa, mas somente no meado dos anos 80 que a prática pedagógica, com a mudança do foco de ensino para a aprendizagem, começou a ser largamente avaliada (GOMES, 1996). O conhecimento das estratégias disponíveis é uma importante ferramenta para que o educador trabalhe com a conscientização do educando em relação ao prazer de aprender e do desenvolvimento de habilidades. 
Segundo ALMEIDA (1997), as diferentes estratégias como centro decisório do processo de ensino/aprendizagem, focando a aprendizagem, comprova a mudança da prática pedagógica, identificada como tradicional, diretiva e reprodutora, para uma pedagogia ativa, criativa e dinâmica, apoiada na descoberta, na investigação, na cooperação e no diálogo entre todos os envolvidos no processo.

Paulo FREIRE (1987) reforça o paradigma de cooperação e diálogo, afirmando que não há docência sem discência e que, apesar das diferenças que as conota, elas se explicam: quem ensina aprende ao ensinar, e quem aprende ensina ao aprender.

Esse conceito valoriza de forma incalculável a criatividade do educador; e atribui uma maior consciência pedagógica, uma vez que educação não é uma simples porta para o mercado de trabalho, mas um meio de livre acesso com destino a um mundo que necessita de verdadeiros cidadãos formados dentro dos princípios de valores absolutos (amor, paz, não-violência, verdade, ação correta) e relativos (honra, paz, amor, ética, criatividade, cidadania). Não se deve, contudo, esquecer do teor técnico necessário em todo profissional.

"A interação entre quem ensina e quem aprende é uma realidade, uma expressiva e significativa realidade que faz com que o comportamento de um sirva de estímulo ao comportamento do outro. Essa interação, na sala de aula, se dá exatamente como conseqüência dos procedimentos planejados e que proporcionam a realização das modificações pretendidas de comportamento" ( TURRA ,1982, p.127)

O uso das estratégias disponíveis com o intuito de formar profissionais conscientes de sua importância dentro do contexto sócioeconômico é reforçado pela mudança das terminologias dentro do contexto educacional.

A palavra "professor", por exemplo, cedeu lugar em sala de aula, à palavra "educador". Este novo termo conota que o profissional, agora, é portador de responsabilidades mais conscientes. 
"O professor tem um compromisso mais restrito, qual seja, transmitir certo conteúdo de conhecimentos relativos à sua disciplina. $O$ educador, por sua vez, é aquele de quem se recebe exemplo e lição de vida. $O$ educador não precisa ser, necessariamente, um professor, mas se o for, possui um compromisso mais amplo com o educando, isto é, além de transmissão de conhecimentos, sua presença demonstra ao educando que esse conhecimento tem um sentido transcendental" (MARTINS, 1990, p.154).

Percebe-se nesse contexto que o objetivo e a responsabilidade de uma disciplina é maior do que se possa prever, e para o sucesso de todo processo de planejamento, definir quais as estratégias que poderão ser utilizadas e em qual momento, passa a ter uma importância relevante dentro do processo de desenvolvimento de profissionais capacitados tecnicamente e capazes de atuar de forma significativa num contexto sócio-econômicocultural globalizado.

MORAN (1997) diz que se deve buscar novas estratégias e diferentes recursos técnicos, em diferentes momentos, procurando desencadear um processo de ensinar compartilhado, coordenado pelo educador com profunda participação dos educandos. Há uma maior probabilidade de educar em um ambiente comunicacional participativo, interativo e vivencial, uma vez que educar é mais do que simplesmente trabalhar conteúdos técnicos específicos e necessários, é ajudar a formar pessoas.

Por esse autor, educar compartilhado é desenvolver os indivíduos para uma autonomia e cooperação, é um processo de "ensinar a caminhar sozinho e em grupo", isso implica o desenvolvimento da habilidade de aprender a aprender, trabalhar em equipe, ajuda mútua, não só para satisfazer às necessidades do mercado atuais, mas também satisfazer uma necessidade pessoal e social.

A aplicação da mesma estratégia de ensino, independentemente do tipo de assunto a ser abordado, comprova que, muitas vezes, devido à falta de um planejamento eficaz, perde-se a consciência de que existe, dentro de um mesmo local (sala de aula), indivíduos com diferentes predisposições, 
estilos de aprendizagem, expectativas gerando uma desmotivação das pessoas envolvidas prejudicando o alcance dos objetivos propostos.

Negligenciando os estilos de ensino aprendizagem existentes, os recursos técnicos disponíveis e as diferentes estratégias de ensino existente, corre-se o risco de perder o foco do processo por parte de quem aprende e conseqüentemente de quem ensina.

Para minimizar as dificuldades existentes dentro da prática pedagógica, um dos recursos seria conhecer algumas estratégias de ensino, suas características. Com isso, dentro de contextos específicos, optar por aquela que melhor auxilie no processo de ensino e aprendizagem do conteúdo programático, desenvolvendo o plano de ensino o mais próximo possível da realidade.

Diretamente ligada à operacionalização do planejamento está a avaliação, que deve ser contínua e corretiva, pois é um importante instrumento de averiguação se os meios utilizados estão em conformidade com as metas e objetivos estipulados.

\section{4 Avaliação}

A avaliação deverá sempre ser constante e praticada com um intuito corretivo, independentemente da estratégia utilizada e dos objetivos propostos, a fim de direcionar o sucesso do processo de ensino e aprendizagem.

Em alguns momentos, quando se avalia um processo de ensino/aprendizagem preocupa-se mais em verificar a eficácia da ação pedagógica realizada na Instituição de Ensino, em avaliar o trabalho do professor e o desempenho do aluno/classe através de notas e conceitos, do que analisar o processo em si (MASETTO, 1990).

TURRA (1982) reforça que a avaliação é um método de adquirir e processar evidências necessárias para melhorar aprendizagem e o ensino. Funciona como um sistema de controle de qualidade, pelo qual pode 
determinar, etapa por etapa a efetividade do meio utilizado. Caso o insucesso seja verificado, a análise durante o processo facilita a intervenção, garantindo um reposicionamento de ações ou metas.

O processo de avaliação tem como função maior fornecer um feedback, para as pessoas envolvidas no processo, uma vez que ele está ligado ao processo de aprendizagem.

O processo de avaliação deve ser pensado, planejado e realizado de forma coerente e condizente com os objetivos, portanto deve ser contínuo e estar voltado para o desempenho da aprendizagem, sem esquecer, contudo de incidir também, sobre o desempenho do ensino, onde o responsável poderá ser o educador, ou coordenador comprometido com os assuntos a serem abordados.

A avaliação pode e deve ser realizada de diferentes formas, sempre com o intuito de diagnosticar sucessos e insucessos do processo e estratégias utilizadas, ou seja, avaliar o planejamento como um todo, tendo como referencia o aprendizado efetivo e ocorrido.

Segundo POWELL (1998) e MASSETO (1990), em diferentes momentos, distintas formas e modalidades de avaliação devem ser planejadas:

1) DIAGNÓSTICA - verifica o conhecimento do aluno e/ou grupo de alunos quanto ao assunto que deverá ser trabalhado (geralmente realizado no início do ano letivo ou de um assunto novo);

2) FoRMATIVA - aplicada durante o desenvolvimento do assunto com a finalidade de detectar dificuldades e minimizá-las;

3) SOMATIVA - aplicada no final para verificação de quais objetivos foram e quais não foram atingidos e em que extensão.

Dependo da metodologia aplicada pode-se lançar mão de várias formas de avaliação, ou ainda contar com uma auto-avaliação realizada pelos alunos, mas ela deve sempre ser realizada de forma contínua a fim de garantir o sucesso do processo como um todo (MARTINS, 1990). 


\section{ESTRATÉGIAS DE ENSINO E APRENDIZAGEM}

Após o planejamento e a definição dos objetivos, a escolha da melhor estratégia para operacionalizá-lo se torna fundamental.

KURI e GIORGETTI (1994) afirmam que o termo estratégia de ensino designa um conjunto de atividades didáticas, selecionadas e organizadas pelo professor, que servirão como meios de ajuda para que os objetivos sejam alcançados. A estratégia abrange métodos, técnicas e recursos institucionais.

POWEL (1996), em outra proposta, define estratégia como o método de trabalho a ser usado durante parte ou todo desenvolvimento de uma disciplina.

De acordo com MASETTO (1990), estratégia de ensino é o conjunto de métodos e técnicas que serão utilizados a fim de que o processo de ensino/aprendizagem se realize com êxito. Levando em consideração o momento do ensino e a motivação necessária para o sucesso da metodologia escolhida, focaliza a aprendizagem do educando, respeitando sua liberdade, levando-o, porém, à assimilação de diretrizes, atitudes e valores que o tornarão melhor em seus múltiplos aspectos.

Dentre os métodos e técnicas mais utilizados no ensino de Engenharia destacam-se: aula expositiva, projeto, seminário, trabalho em 
grupo, estágios, aulas em laboratórios, cada um deles apropriado para cada situação (BERBEL, 1994).

\subsection{Tipos de Ensino}

Como o processo de ensino aprendizagem requer uma cooperação entre quem aprende e quem ensina, a motivação deverá ser estimulada desde o início do processo, uma vez que é considerada, por muitos, como um dos fatores determinantes e intrínsecos para o sucesso na utilização de determinadas estratégias. Nesta situação, a motivação consiste nas causas e nos impulsos de comportamento que desencadeiam uma predisposição de aprender. O desenvolvimento de uma necessidade que leva o indivíduo a buscar o conhecimento com um objetivo, despertando, sustentando e dirigindo sua aprendizagem.

"No processo de ensino/aprendizagem, deve-se transformar o assunto a ser ensinado em necessidade pessoal do aluno. A partir daí desencandeiase todo um processo que gera uma reação do educando para satisfazer a necessidade, facilitando a aprendizagens". MARTINS (1990, p.26)

Convém lembrar que o processo de motivação deve ser uma situação consciente por parte do educador. As estratégias do ensino, formadas pelo conjunto de métodos, técnicas e recursos, devem ser utilizadas com segurança a fim de que o processo de ensino/aprendizagem se realize com êxito. Toda estratégia tem por objetivo o direcionamento da aprendizagem e a respeitabilidade à liberdade do educando, motivando-o para o desenvolvimento holístico, englobando a assimilação de diretrizes e conteúdo, mudança de atitudes e valores, sempre com o intuito de melhorálos como pessoas e conseqüentemente como profissionais (RIPPER,1996)

Conforme MARTINS, (1990) e ABREU, (1990) afirmam são várias as estratégias de ensino existentes e que podem ser utilizadas, de acordo com a necessidade, para alcançar aos objetivos planejados e podem ser 
implementadas de duas formas: individualizada ou em grupo, de acordo com o tipo de habilidade e conteúdo que deverá ser trabalhado.

4.1.1 $O$ ensino individualizado engloba técnicas e atividades que permitem ao educando a oportunidade de seguir seu próprio ritmo, selecionar alternativas que lhe permitam atingir aos objetivos de ensino e planejar suas próprias atividades de aprendizagem.

O ensino individual enfatiza o desenvolvimento pessoal do indivíduo uma vez que incentiva um desenvolvimento da sua habilidade de aprender a aprender, de assimilar, questionar, criticar e solucionar problemas de uma forma coerente e sem, necessariamente, a ajuda de outras pessoas.

Segundo NÉRICI (1992), este tipo de ensino propicia o desenvolvimento de habilidades específicas como:

$\checkmark$ Definir e seguir o programa com ritmo próprio;

$\checkmark$ Selecionar a melhor atividade, dentre as alternativas, que the permitam atingir ao objetivo;

$\checkmark$ Aprender a planejar suas atividades de aprendizagem.

Dentre as estratégias que incentivam esse tipo de ensino e aprendizagem encontram-se: instrução audiotutorial, instrução assistida por computador, instrução programada, solução de problemas, leituras, etc.

4.1.2 O ensino em grupo engloba técnicas e atividades que visam ao aproveitamento das capacidades de interação do individual com o grupal. Neste conceito fundamenta-se a argumentação de que o homem é um ser social que interage permanentemente com o meio através de suas capacidades e de suas necessidades.

NÉRICI (1986) e BERBEL (1994) afirmam que a maioria dos trabalhos desenvolvidos durante os cursos de $3^{\circ}$ grau prioriza este tipo de ensino, 
principalmente por ser a capacidade de trabalhar em equipe uma das habilidades mais solicitadas pelo mercado profissional.

O estudo em grupo oportuniza o desenvolvimento pessoal dos componentes uma vez que além de incentivar a participação mútua, propicia um intercâmbio de idéias e experiências individuais. Enfim, é uma estratégia que facilita as condições de encontrar melhores soluções para as situações problemáticas de uma forma mais simples e cooperativa.

Segundo NÉRICI (1986) e MARTINS (1990): este tipo de ensino propicia o desenvolvimento de algumas habilidades específicas como:

$\checkmark$ Estímulos da capacidade de assimilação e memorização.

$\checkmark$ Incentivo para entender e observar as questões através de outras perspectivas;

$\checkmark$ Incentivo ao prazer de raciocinar sobre assuntos e posturas;

$\checkmark$ Estímulo à predisposição a escutar de modo compreensivo a outras pessoas;

$\checkmark$ Incentivo à cooperação e não a competição;

$\checkmark$ Estímulo da iniciativa e da criatividade;

$\checkmark$ Estímulo à superação de temores e inibições, superando limites de insegurança;

$\checkmark$ Desenvolvimento de espírito de tolerância;

$\checkmark$ Estímulo à ação objetiva e impessoal.

Embora o desenvolvimento do processo seja em equipe, as características pessoais e individuais são observadas, desenvolvidas e aprimoradas durante todo o processo. Neste tipo de ensino os princípios da holística se aplicam, porque as partes que compõem o "todo", quando bem trabalhadas, propiciam ao "todo" chegar aos objetivos e resultados almejados.

Atualmente, tanto no ensino individualizado quanto em equipe, temse, como aliada, a tecnologia e todas as facilidades dela provindas, podendo 
ser utilizada como mais uma ferramenta disponível para a execução dos trabalhos, como um meio motivacional grupal e individual eficiente, sempre direcionando para os objetivos planejados do processo.

A opção pela utilização do ensino individualizado ou em grupo dependerá do assunto a ser abordado, peculiaridades particulares dos estudantes, disponibilidade de tempo do educador, tanto para o planejamento quanto para a operacionalização do planejado, recursos disponíveis e dos objetivos específicos e gerais.

\subsection{Estratégias que Auxiliam o Processo de Ensino e Aprendizagem}

Segundo MASETTO (1990), as estratégias escolhidas pelo professor podem ou não favorecem o dinamismo das aulas.

Dentre as variáveis que possuem implicação direta no sucesso da atividade didático-pedagógica citam-se: a energia pessoal das pessoas envolvidas, o conteúdo da disciplina, o vínculo do grupo já estabelecido, período (manhã, tarde ou noite) do curso, etc.

Entretanto, nenhum desses fatores, que quando tomados isoladamente, geralmente escapam a qualquer possibilidade de controle por parte do educador, tem uma influência tão forte e decisiva para o sucesso da prática pedagógica como a estratégia. Em decorrência disso, as estratégias são aliadas poderosas da atuação sobre a motivação dos alunos.

Há professores que são excelentes especialistas em seus conteúdos, e também capazes de estabelecer um clima de descontração e de diálogos em sala de aula - apesar destes dois fatores facilitarem a aprendizagem; professores, talvez desinformados, não dão o devido valor à utilização da estratégia escolhida e repete uma única maneira de "dar aula" do começo ao fim do ano ou do semestre.

A utilização de uma única estratégia para a disciplina faz com que, depois de 2 ou 3 meses, a produção da classe caia, pois a capacidade 
intelectual do educador não é suficiente para manter os educandos em alerta. É como se a classe, como um todo, começasse a se sentir "cansada" daquelas aulas, desprezando o conteúdo, embora reconheça sua validade para seu desenvolvimento profissional (ABREU, 1990).

A variação das estratégias existentes permite que se atenda às diferenças individuais existentes, e com isso possibilita uma efetiva atuação no tocante a desenvolver habilidades técnicas e pessoais. Nesse contexto, alunos com diferentes estilos de aprendizagem terão suas oportunidades de estabelecer um vínculo entre as formas de aprendizagem mais significativo no decorrer do curso (MASETTO,1990).

Além disso, a variação das estratégias favorece o desenvolvimento de habilidade diferenciada, o que não acontece quando se utiliza a mesma estratégia durante um longo período de tempo. Por exemplo, se um curso todo é dado sob forma de aulas expositivas, não estará desenvolvendo a habilidade de trabalhar em grupo, de se expressar, de resolver problemas, apesar de estar desenvolvendo muito a capacidade de receber informações através da audição e visão.

A variação das estratégias favorece o aprendizado (alunos), mas a variação das estratégias favorece também o educador (professor) por tornar o curso um pouco mais dinâmico e desafiador, á medida que exige uma renovação e captação de informação desenvolvendo a flexibilidade e criatividade ao "dar as aulas" e propiciando uma avaliação mais efetiva do processo e do planejamento.

As variações das estratégicas só são viáveis a partir do momento que as possibilidades e os objetivos gerais e específicos são conhecidos dentro das diretrizes do conteúdo programático.

Evidentemente, é muito necessária uma boa dose de bom senso durante as variações das estratégias. Um parâmetro eficiente sobre como e quando variá-las vem dos objetivos e da experiência acadêmica individual do educador, uma vez que as estratégias devem ser apenas um meio para atingi-los. 
Se o educador dispõe dos seus planos , "aula a aula", uma revisão periódica permite que tenha uma visão de conjunto e uma análise crítica do desempenho, uma vez que a variação excessiva, assim como a repetição excessiva pode não ser ideal, sem contudo esquecer da importância do feedback recolhido dos alunos durante a atividade (MOREIRA, 1997).

MASETTO, (1990) e MARTINS, (1990) observam que as estratégias de ensino, pertencem a 6 categorias:

1) Situações simuladas que reproduzem ou se assemelham à situação real pela equivalência;

2) Situações que colocam os estudantes em confronto com situações reais;

3) Estratégias que dividem a classe em pequenos grupos;

4) Situações que exigem a presença de um especialista e/ou uma preparação prévia;

5) Estratégias em que o educador centraliza a ação;

6) Pesquisas e Projetos.

\subsubsection{Situações simuladas que reproduzem ou se assemelham à realidade pela equivalência}

Nessas estratégias o modelo a ser estudado engloba alguma situação que pertence à realidade do aprendiz, e este tem que se desenvolver, analisando criticamente essa situação, encontrando solução para o problema e levando em conta todos os componentes envolvidos (MARTINS, 1990)

As situações podem focar-se em uma aprendizagem conceitual como em um desenvolvimento de habilidades como trabalhar em equipe, expressar oralmente e verbalmente uma posição, independência social, etc. 
Nesta categoria a situação real é apresentada de forma bem mais simplificada da real, o que permite o julgamento, sem se perder em detalhes, que, no momento, não são significativos. Objetivam desenvolver a capacidade de analisar e encaminhar soluções a fim de preparar os indivíduos para enfrentar situações reais e complexas.

As atividades englobadas nessa categoria, segundo MASETTO (1990) e MARTINS (1990), são:

a) DRAMATIZAÇÃO, DESEMPENHO de PAPÉIS, Jogos dRAMÁTICOS - Dado um objetivo e um papel a cada participante, deve-se procurar desenvolver e trabalhar personagens e situações ocorridas, o mais próximo possível da realidade;

b) Estudo DE CASO: Baseado em um caso real, fictício ou adaptado à realidade dos estudantes, deve-se chegar a possíveis conclusões, utilizando conceitos previamente estudados e analisados. Nesta categoria, é possível, em algumas situações, o emprego da atividade de estudo teórico de determinados assuntos, como forma de motivação e descobertas de conceitos relacionados.

\subsubsection{Situações que colocam os estudantes em confronto com situações reais}

Estas estratégias objetivam a preparação do aprendiz para uma ação profissional efetiva, sob a orientação de um educador e ou de um profissional mais experiente, tendo como meta viver e lidar com situações e problemas reais (MARTINS,1990). Elas estão diretamente ligadas à área de atuação escolhida e ao objetivo das disciplinas e geralmente envolvem: Estágios, Visitas técnicas e Projetos de final de curso. 


\subsubsection{Estratégias que dividem a classe em pequenos grupos}

Nesta categoria, pequenos grupos são formados com o objetivo específico de desenvolver a capacidade de observação e raciocínio crítico pessoal e grupal. Mesmo em pequenos grupos há a possibilidade do acompanhamento do desenvolvimento individual, o que ocorre quando, ao aprofundar uma discussão, deixa-se liberdade para a exposição de posições pessoais do grupo e individuais, de forma tranqüila MARTINS (1990).

Nessa atividade, desenvolve-se a capacidade de analisar um "problema" em equipe, de forma sistemática e independente. Ao lançar mão desta estratégia, há a necessidade prévia da uma confiança mútua na capacidade pessoal de cada um pertencente ao grupo, uma vez que, durante o processo, o auxílio e a intervenção dos integrantes do grupo serão constantes.

Segundo MASETTO (1990), MARTINS (1990) e FAGUNDES (1997), fazem parte dessa categoria:

a) Pequenos grupos com uma só tarefa - Nesta atividade todos recebem a mesma informação e devem atingir o mesmo objetivo, no final pode-se usar de outras estratégias para dar um feedback dos trabalhos executados, como a criação de um texto sobre as etapas executadas;

b) Pequenos grupos com tarefas diversas - Nesta atividade cada grupo recebe instruções e informações diferentes, tendo como objetivo aprofundar o estudo de um determinado tema já abordado. No final, a exposição é feita para toda a classe e todos participam para um fechamento mais amplo sobre o conteúdo, solidificando conhecimentos e informações já trabalhadas; 
c) GRUPO DE INTEGRAÇÃo HORIZONTAL E VERTICAL - Essa estratégia é composta por dois momentos:

I. Primeiro momento: após dividir a sala em pequenos grupos ${ }^{1}$ é dado o mesmo assunto a todos, (se possível o mesmo assunto abordado de maneira diferente), e iniciam-se pesquisas e discussões sobre o tema;

II. Segundo momento: Há a criação de novos grupos, agora compostos por um participante de cada grupo, que terá a responsabilidade de relatar o que foi discutido pela sua equipe; explicar a conclusão obtida e rediscuti-la com o intuito de aumentar a percepção do assunto, através dos diversos ângulos, pelos quais o tema foi abordado.

O tempo determinado e monitorado para a discussão é fundamental para o andamento eficaz dessa estratégia;

d) Grupo de VERbalização e GRUPO de observaçÃo - Nesta situação, há a divisão do número de pessoas em dois grupos, onde um é responsável pela discussão do tema e outro pela observação. A observação deverá ser instruída, ou seja, deve haver uma reunião prévia sobre conceitos técnicos, teóricos e posturas a serem observados durante a discussão;

As sugestões de características poderão ser observadas: se há a interposição entre a prática e os conceitos estudados; se todos os participantes estão tendo oportunidade de falar/comunicar-se ou, se, para se fazer ouvir, é necessário elevar o tom de voz; se o grupo estabeleceu regras para si mesmo, se a discussão está adequada à aula, enfim o objetivo a ser observado é flexível e deve vir ao encontro dos objetivos relacionados ao assunto a ser abordado tendo como norteador das habilidades a serem observadas características pessoais e grupais específicas.

e) DiÁlogos sucessivos - Técnica empregada para demonstrar que para um mesmo tema há diversas percepções, sem que, contudo, haja uma 
certa ou errada. Nessa estratégica há a necessidade da formulação exata do tempo disponível para a realização da atividade e de um número par de participantes;

O procedimento operacional seria cada um escolher seu par e iniciar o diálogo sobre um tema. No final do tempo há uma troca de pares, seguida de uma nova discussão do mesmo tema. Um dos objetivos é trazer uma assimilação de que, conforme houver a mudança dos pares, haverá a reformulação de proposições e um aprimoramento na maneira de se expressar e argumentar visualizando entender o assunto sobre diversos ângulos.

f) GRUPOS DE OPOSIÇÃo - Nessa técnica são formados dois grupos, um com a finalidade de defender uma idéia e outro de atacá-la. O tempo de discussão deve ser determinado previamente, assim como o tempo de uma reunião, entre os componentes de cada grupo, necessário para formular argumentações e procedimentos de defesa e/ou ataque ao tema. Um alerta deve ser feito quanto ao fato desta estratégia lidar, de maneira implícita, com a competição entre os grupos: deve-se conhecer bem os componentes do grupo, para que tudo ocorra dentro dos padrões normais e saudáveis de competitividade e cooperação, e que haja, efetivamente, um desenvolvimento pessoal e grupal neste sentido;

g) Pequenos grupos para formular questões - Nesta técnica há a divisão da sala em grupos, onde cada um deles elabora questões sobre 0 tema abordado e transmite-as aos demais com o intuito de obter as respostas.

\footnotetext{
${ }^{1}$ A palavra grupo e equipe neste capítulo são utilizadas como sinônimos: várias pessoas trabalhando cooperativamente para alcançarem um objetivo comum.
} 


\subsubsection{Situações que exigem a presença de um especialista e/ou uma preparação prévia}

Uma das estratégias mais utilizadas em ensino superior, por necessitar uma certa maturidade e independência intelectual por parte dos aprendizes. Podem ser combinadas com as diversas estratégias existentes e há opção da presença de um especialista no assunto e a revisão de trabalhos na área, por parte dos envolvidos. BORDENAVE (1978).

Segundo MASETTO (1990), MARTINS (1990) e FAGUNDES (1997), desta categoria, fazem parte:

a) SemináRIo - Esta estratégia gira em torno de um tema a ser estudado em profundidade. Após o estudo sobre o assunto a ser trabalhado, os resultados parciais são sintetizados, levando a obter conclusões, ou seja, cada pessoa, a partir do tempo de preparação e estudo, torna-se um "especialista em uma parte de um problema ou assunto" e transmite ao resto da classe seu conhecimento e suas conclusões.

Há a possibilidade de uma disciplina inteira ser dada em forma de seminário.

Para o emprego do seminário exige-se uma independência intelectual e uma maturidade por parte de todos os envolvidos pois a capacidade de organizar, sintetizar e manter o nível geral de desenvolvimento do educando se torna fundamental.

b) Painel - Nessa estratégia, há um tema abordado por um pequeno grupo, chamado de "especialistas" e convidados a falar e debatê-lo sob a orientação de um moderador (educador ou participante do grupo). Cada componente expõe suas opiniões a respeito do tema. É importante que o tema planejado tenha sido desenvolvido pelo educador em aula e que haja o mínimo de domínio do assunto por parte dos integrantes da atividade.

O painel não leva necessariamente a conclusões. Ao contrário, pode levantar muitos pontos que se apresentam à classe sob forma de perguntas e que podem gerar novas pesquisas e exposições. 
c) Simpósıo - Nessa estratégia cada expositor prepara uma parte de um tema e depois, utilizando o tempo pré-definido, expõe o assunto para um grupo de pessoas. Perguntas são feitas após a apresentação, nunca durante a apresentação. Geralmente as questões são de esclarecimentos, uma vez que a função principal do simpósio é de transmitir informações. $O$ educador funciona como organizador muito mais do que como transmissor do conhecimento.

\subsubsection{Estratégias em que o educador centraliza a ação}

Nesta estratégia o educador atua como centralizador que fala o tempo todo sem qualquer interrupção ou manifestação ativa por parte dos estudantes, e como coordenador e orientador. A classe toda é tomada como um grupo apenas, e procura-se estabelecer uma discussão sobre um determinado assunto.

Para o sucesso dessa estratégia o educador deverá deter o conhecimento do interesse e objetivo intrínseco do conteúdo, ter o domínio teórico e prático do assunto, assim como estar atualizado sobre os desenvolvimentos mais recentes sobre o tema.

Nessa categoria, segundo MASETTO (1990) e MOREIRA (1997) estão:

a) Aula Expositiva - Esta é a estratégia mais empregada nas Instituições de Ensino Superior e utilizada, por muitos, como única opção existente em determinadas disciplinas para trabalhar conteúdos específicos. Não há nada errado com o emprego constante de nenhuma das estratégias existentes, o importante é averiguar quando e qual estratégia de aprendizagem é a melhor para se alcançar, com eficácia, objetivos propostos pela disciplina ou por determinado assunto.

MASETTO (1990), ABREU (1975) e MARTINS (1990) em seus estudos afirmam que esta estratégia é eficiente, uma vez que através dela o educador, com uma boa vivência prática na disciplina que ministra, será 
capaz de relacionar o assunto teórico com a prática utilizando isso como agente motivador na execução do trabalho. Nesta estratégia, é possível o educador expor recentes descobertas, ou novas teorias relacionadas, atualizando o seu conhecimento através de livros e apostilas. Através de preleção, o educador pode transmitir explicações sobre pontos difíceis, ressaltar pontos importantes e sintetizar informações que, de outra forma, o grupo não teria acesso.

Para MILLER (1967) as aulas expositivas preparadas adequadamente, por si só, já garantem o mínimo de sucesso da estratégia.

Segundo o mesmo autor, há algumas orientações que poderiam ser utilizadas para a preparação adequada do material e da aula a ser desenvolvida.

b) Debate com a classe toda - O debate é uma estratégia difícil de ser utilizada com eficiência, pois além de exigir habilidades específicas por parte do educador, exige o total domínio do conteúdo a ser abordado e, impreterivelmente, todos devem trazer algum material preparado de antemão para a discussão. Nessa categoria, todos os estudantes devem ser ouvidos, o que pode ser um problema caso o tempo não seja minuciosamente avaliado e monitorado.

MASETTO (1990, p.81) afirma que "o professor precisa saber de suas habilidades como organizador dos trabalhos dos grupos, tais como obedecer ao ritmo do grupo, garantir a participação de todos, aceitar não monopolizar a discussão (muito embora, se o fizesse, terminaria o assunto e a discussão bem mais rapidamente), e trazer o grupo de volta ao tema central sempre que houver dispersões, prepara o ambiente físico da sala de aula, controlar o passar do tempo".

Apesar de ser uma das estratégias que requerem maior tempo de preparo e número de habilidade por parte do educador, é ideal para se desenvolver habilidades adicionais como a de argumentação, raciocínio lógico e crítico de assuntos e temas relacionados, assim como uma postura de respeito quanto à posição e a opinião alheia. 


\subsubsection{Pesquisas e Projetos}

Pesquisas e projetos, assim com as aulas expositivas, são largamente utilizados no ensino superior.

Pesquisas e projetos $^{2}$ podem ser utilizados para algumas aulas específicas ou construir uma estratégia para um semestre inteiro. Entretanto, o educador precisa orientar, cuidadosamente, todo o processo, e criar um clima de responsabilidade cooperativa e de co-responsabilidade, para que as pessoas envolvidas percebam seu desenvolvimento e assumam a responsabilidade de sua aprendizagem.

Nesta atividade existem algumas etapas, que se forem seguidas, podem minimizar desconfortos iniciais provocados, muitas vezes, pela falta de maturidade e conhecimento das pessoas envolvidas (MASETTO,1990; MARTINS,1990).

São elas:

$\checkmark$ Motivar os estudantes: participando-os de quão importante e rica é esta atividade de pesquisa e projeto, e como isso está relacionado ao processo de aprendizagem individual, grupal e ao amadurecimento profissional;

$\checkmark$ Discutir critérios para escolha do assunto a ser pesquisado junto com as pessoas envolvidas;

$\checkmark$ Escolher 0 assunto a ser pesquisado e: Definir precisamente o problema; Escolher uma estratégia de trabalho e Escolher a forma de exposição dos resultados;

$\checkmark$ Elaborar uma rotina de coleta e análise dos dados coletados;

$\checkmark$ Conclusão - Apresentação efetiva do trabalho pesquisado e do projeto realizado.

\footnotetext{
2 A estratégia de pesquisa e a de projeto estão co-relacionadas, uma vez que para desenvolvimento de
} projetos, a pesquisa deverá ser realizada e vice-versa. 
Para que essa estratégia alcance os objetivos propostos, há a necessidade de que os temas a serem trabalhados estejam próximos a realidade profissional dos envolvidos.

Segundo MOREIRA (1997), o projeto, por principio, deve partir da realidade das pessoas envolvidas e estar o mais perto possível seu ambiente normal de atuação. Caso isso não ocorra, o produto que se tem é o modelo acadêmico convencional, onde a idéia de ensino-aprendizagem parte mais de um programa pré-estabelecido - ensino - do que propriamente da interação entre a realidade e as necessidades das pessoas envolvidas aprendizagem.

Nessa estratégia, o educador atuará no sentido de ajudar a transformar as informações coletadas em conhecimento, de modo que haja o desenvolvimento de atitudes conscientes relacionadas ao perfil profissional a ser formado, desenvolvendo e exercendo o poder da escolha e de como trabalhar o conhecimento adquirido (GARDNER, 1995).

Para GARDNER (1994), um projeto ou uma pesquisa fornece uma oportunidade para que as pessoas envolvidas disponham de conceitos e habilidades previamente dominadas a serviço de uma nova meta ou empreendimento, com isso aprimorando estas habilidade e desenvolvendo outras diferenciadas.

O trabalho com projeto vem demonstrando ser um grande aliado ao processo de ensino aprendizagem, não apenas porque motiva de uma forma diferenciada, as pessoas envolvidas pela sua total interatividade, mas também porque propicia uma maior formação profissional e pessoal ágil do conteúdo programático.

Neste sentido RIBEIRO (1998), afirma que projetos são verdadeiras fontes de criação porque, enquanto se passa por processos de pesquisas, aprofundamento, análise, depuração e criação de novas hipóteses, colocase, constantemente, em prova, as diferentes potencialidades dos elementos do grupo, assim com suas limitações, objetivando-se o desenvolvimento positivo dessas características, podendo, simplesmente serem definidos 
como ferramentas que possibilitam trabalhar com velhos conteúdos de maneira atraente e interessante, e ainda, focar o ensino e a aprendizagem.

O que torna este processo complexo é o fato de que ao adquirir novos conhecimentos deve-se relacioná-los aos já apreendidos a fim de reconstruir um novo referencial. Isso requer uma grande habilidade e controle por parte do educador, que geralmente assume a postura de orientador durante o processo,levando em conta o material a ser elaborado e o tempo para que $o$ trabalho seja realizado com qualidade.

Um projeto tenderá, naturalmente, a passar por várias etapas, correlacionadas, assim, a seqüência lógica torna-se fundamental para que as metas definidas sejam alcançadas dentro do tempo disponível. A estratégia parte de um problema inicial (hipótese), verifica necessidades e a utilidade de trabalhar sobre esta hipótese, transforma as informações coletadas e emitidas em bases de conhecimento para iniciar o processo de estruturação do conteúdo coletado (resultados), re-estrutura todo conteúdo elaborado, provocando novas hipóteses. FIGURA 4.1.

Durante todo o processo a avaliação se torna necessária para a devida orientação e comprovação da real necessidade do projeto e da pesquisa (GARDNER, 1994).

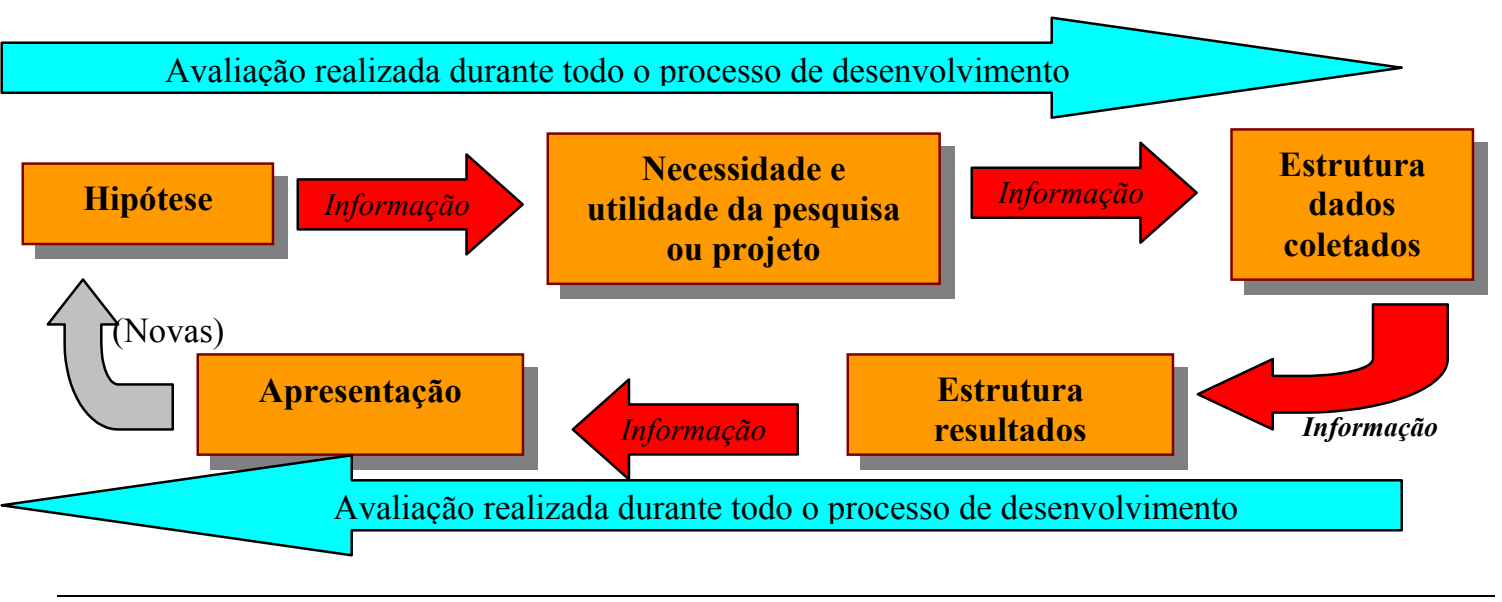

FIGURA 4.1 - Desenvolvimento da atividade de Pesquisa e de Projeto 


\section{Ciclo de aprendizagem por projetos}

$\mathrm{Na}$ aprendizagem por projeto, o ciclo de desenvolvimento da atividade, também estrutura a aquisições do conhecimento das pessoas envolvidas (RIBEIRO, 1998).

Enquanto ocorre o processo de análise da hipótese e da necessidade da pesquisa, uma reflexão, por parte das pessoas envolvida está ocorrendo e é neste ponto que se inicia a aprendizagem, através do pensar e planejamento das atividades.

Durante a estruturação do material coletado a criatividade para trabalhar com esses dados possibilita uma nova fase de construção de conhecimento.

Ao estruturar os resultados, verifica-se se o planejado foi atingido. Em alguns casos, os resultados estão acima dos esperados, mas caso não atinjam os objetivos propostos é necessário, num curto espaço de tempo, uma reformulação no planejamento, ou na análise dos dados.

Com os dados estruturados, a apresentação do trabalho é o ponto culminante de todo processo, onde se tem a constatação de tudo que foi aprendido - aquisição de conhecimento e construção do saber. (FIGURA $4.2)$.

Como o processo é constantemente avaliado, a intervenção se torna simples, estruturando-se a assimilação do processo. 


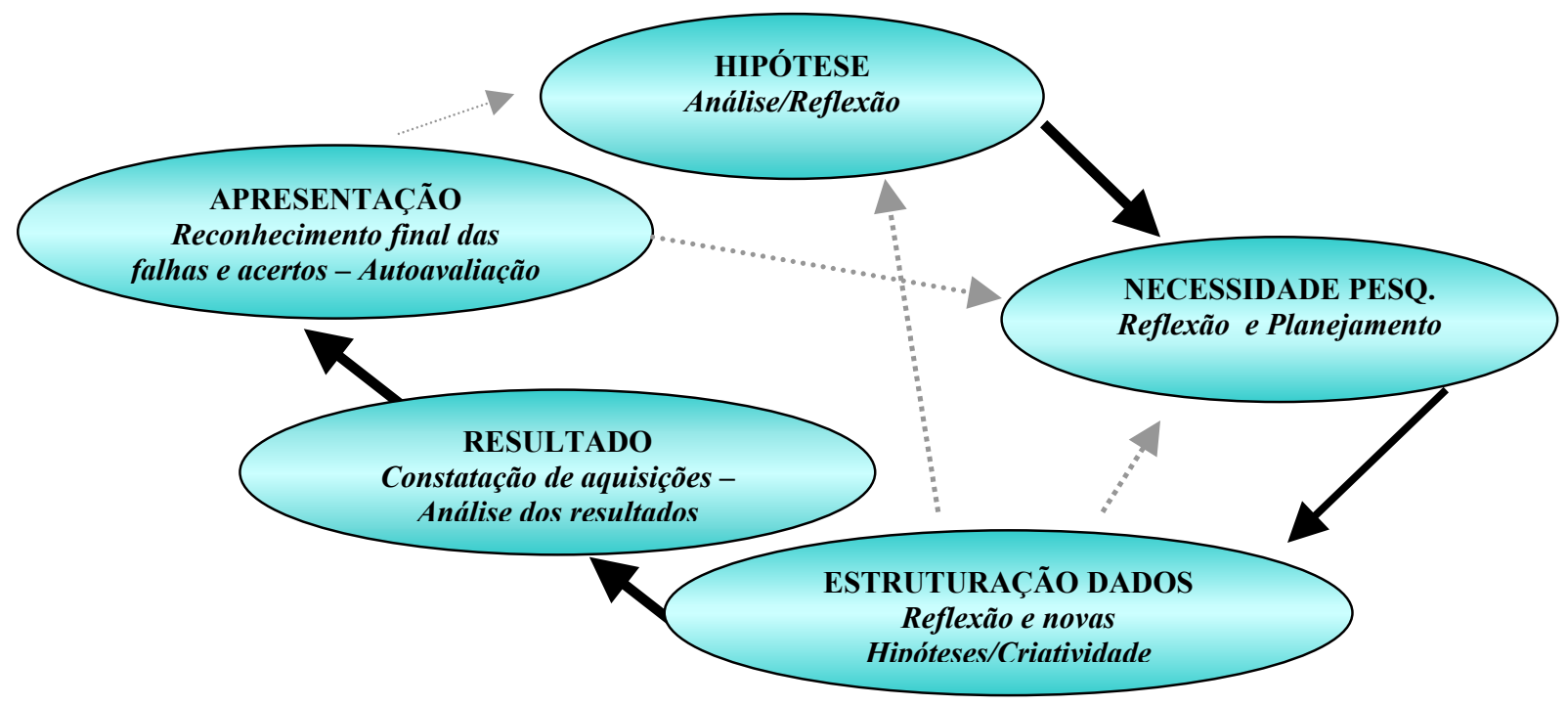

FIGURA 4.2 - Ciclo de aprendizagem por pesquisas e projetos (adptado de Ribeiro:1998)

\subsection{Conclusão Final Sobre as Estratégias Apresentadas}

Para a execução dos planos de aula existem várias opções de estratégias de ensino, algumas, mais utilizadas no ensino de $3^{\circ}$ Grau que outras, cada uma delas com características próprias e complementares o que facilita a utilização de mais de uma num determinado momento da disciplina.

Na tabela 4.1 Apresenta um resumo das categorias e estratégias pertencentes a elas.

Independentemente da estratégia a ser utilizada, a consciência de que existem diferentes estilos de ensino e aprendizagem, que há um número maior de habilidades pessoais e profissionais que podem e devem ser desenvolvidas de acordo com a abordagem da disciplina, deve estar presente durante toda o processo. 
TABELA 4.1: Resumo das categorias e estratégias de ensino (adaptado de MASETTO:1990 e MARTINS: 1990).

\begin{tabular}{|c|c|}
\hline Categoria & Estratégias \\
\hline $\begin{array}{l}\text { Situações simuladas que } \\
\text { reproduzem ou se assemelham à } \\
\text { realidade pela equivalência }\end{array}$ & $\begin{array}{l}\text { Dramatização, desempenho de papéis, } \\
\text { jogos dramáticos } \\
\text { Estudo de caso }\end{array}$ \\
\hline $\begin{array}{l}\text { Situações que colocam os } \\
\text { estudantes em confronto com } \\
\text { situações reais }\end{array}$ & $\begin{array}{l}\text { Estágios } \\
\text { Visitas Técnicas } \\
\text { Projeto de final de curso }\end{array}$ \\
\hline $\begin{array}{l}\text { Estratégias que dividem a classe } \\
\text { em pequenos grupos }\end{array}$ & $\begin{array}{l}\text { Pequenos grupos com uma só tarefa } \\
\text { Pequenos grupos com tarefas diversas } \\
\text { Grupo de integração horizontal e } \\
\text { vertical } \\
\text { Grupo de verbalização e grupo de } \\
\text { observação } \\
\text { Diálogos sucessivos } \\
\text { Pequenos grupos para formular } \\
\text { questões } \\
\text { Grupos de oposição }\end{array}$ \\
\hline $\begin{array}{l}\text { Situações que exigem a presença } \\
\text { de um especialista e/ou uma } \\
\text { preparação prévia }\end{array}$ & $\begin{array}{l}\text { Painel } \\
\text { Simpósio } \\
\text { Seminário }\end{array}$ \\
\hline $\begin{array}{l}\text { Estratégias em que o educador } \\
\text { centraliza a ação }\end{array}$ & $\begin{array}{l}\text { Aula Expositiva } \\
\text { Debate com a classe toda }\end{array}$ \\
\hline Pesquisas e Projetos & \\
\hline
\end{tabular}

A flexibilidade de utilização de diferentes estratégias para um mesmo assunto ou dentro de uma determinada disciplina serve de uma importante ferramenta para a construção do conhecimento e desenvolvimento de determinadas habilidades, assim como um meio de avaliação de desempenho pessoal de todos envolvidos. 
Essa situação propicia a um constante aprimoramento e um repensar de como um determinado conteúdo poderia ser trabalhado, num próximo momento.

Embora cada conteúdo tenha sua particularidade, todas as estratégias, ao serem bem planejadas e bem aplicadas, garantem uma maior perspectiva de sucesso em relação à meta principal da função do educador que é a de auxiliar na busca para ampliação dos conhecimentos, destrezas, aptidões técnicas, de comunicações e relações humanas pelos indivíduos (RIBEIRO, 1998).

Como, além do repasse do conteúdo específico, deve haver também a finalidade a de se desenvolver habilidades profissionais necessárias, Howard Gardner, professor doutor da Universidade de Harvard, a partir de um estudo científico, classificou quais habilidades poderiam ser desenvolvidas e consideradas fundamentais para a perfeita atuação do Homem na sociedade.

Nessa classificação das habilidades, definidas como inteligência, nota-se que muitas das classificadas por ele são as necessárias e fundamentais para a perfeita adaptação do profissional no mercado atual.

Ao utilizar determinadas estratégias, desenvolvendo inteligências específicas objetivando a melhor preparação do indivíduo como um todo pessoal e profissional, os responsáveis, e as Instituições de Ensino Superior estariam cumprindo uma de suas metas - ajudando na construção do conhecimento técnico e na inserção desse profissional no mercado de trabalho forma efetiva e competitiva. 
CAPítulo 5

\section{MUDANÇA DE PARADIGMAS}

A competitividade, hoje existente aliada às constantes mudanças no ensino superior, altera o quadro do mercado de trabalho que será enfrentado pelo profissional de Engenharia. Com a globalização, fronteiras foram diminuídas e as mudanças provocaram uma pressão considerável pela melhoria da qualidade da educação, uma vez que as instituições de ensino são as responsáveis formais pela preparação de um profissional capaz de lidar com esse panorama (ARAUJO et al., 1998).

Ao focar o profissional dentro do mercado de trabalho, lidando com as mudanças existentes, fica claro o quão importante é a gama de conhecimentos e habilidades que essa pessoa deverá "ter" para se manter, de forma competitiva. Neste contexto, a aprendizagem efetiva se torna mais importante do que o ensino.

A transição do foco de ensino para aprendizagem ou, para ensino e aprendizagem, tem um dos seus alicerces no fato de que o ensino só é eficiente quando ocorre a aprendizagem, que, neste novo contexto vai além da assimilação das informações transmitidas.

Cada vez mais frases como "desenvolver conceitos de valores transdisciplinares" como ética, moral, cidadania, direito e deveres, desenvolver habilidades pessoais específicas como trabalho em equipe, capacidade de aprender sozinho, expressar, escrever, etc, estão tomando seu lugar de 
importância ao lado do desenvolvimento técnico específico (WENK, 1998). Comprova-se, assim, o quanto às mudanças ocorridas no mercado têm suas repercussões nos meios acadêmicos e conseqüentemente nas mudanças de paradigmas institucionais, mercadológicos, educacionais e pessoais. (FIGURA 5.1).

É um processo claro e irreversível a interdependência entre mercadoeducação - sociedade e suas implicações no comportamento e na formação do indivíduo. O sistema social influi no sistema educacional através das exigências que lhe faz mediante novos modelos sócio-econômicos e ideológicos que devem ser transmitidos e trabalhados para que as metas e objetivos propostos pela educação sejam alcançados (BORDENAVE, 1990 e FREITAS 1979).

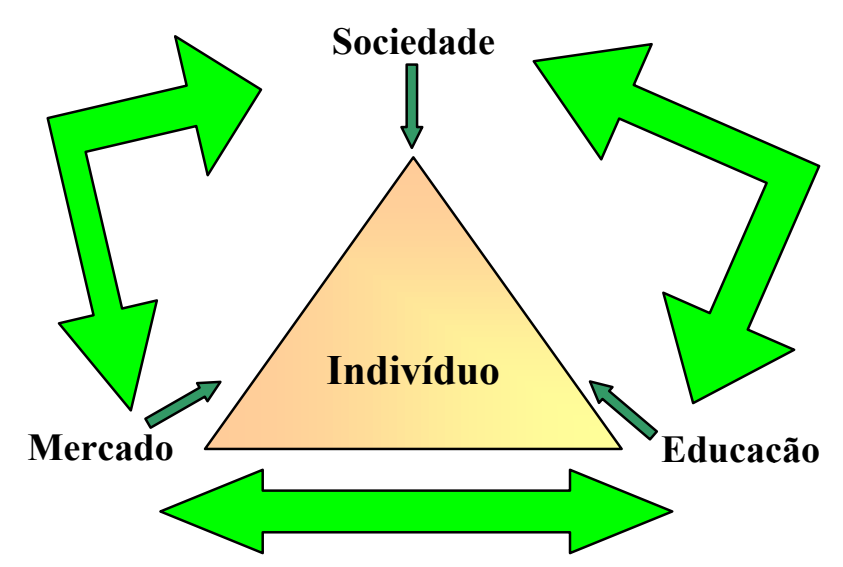

FIGURA 5.1 - Interdependência entre sociedade, educação e mercado: implicações no comportamento individual

No contexto dessa interdependência, toda ação ocorrida em qualquer um deles tem sua reação, imediata ou não, em todos os elos mostrados na Figura 5.1, mas nenhum deles é tão incisivo e tão duradouro quanto às mudanças ocorridas na educação.

A educação, por ser considerada o alicerce de um país, servindo até mesmo como parâmetro para classificação mundial, pode não ter sua implicação em curto prazo - como ocorre com as mudanças no mercado. Essas mudanças 
demoram a ser incorporadas, mas ao acontecerem são fundamentais e decisivas tanto para a sociedade quanto para todos os indivíduos inclusos no processo.

Segundo LOGAREZI (1996), as mudanças educacionais no contexto de Engenharia deverá ser incorporada com a finalidade de agregar ao desenvolvimento técnico as capacidades que são necessárias a todos - saber escrever, saber falar, saber trabalhar em equipe, saber aprender, e principalmente saber utilizar os instrumentos e métodos mais modernos para identificar problemas relevantes e encaminhar soluções visíveis (criativas).

Hoje, sabe-se que empresas necessitam de profissionais cujo perfil vai além da formação acadêmica tradicional e segmentada, exigindo atributos adicionais de caráter, ética e comportamento além de uma visão sistêmica da tecnologia, do conhecimento do mercado e de conceitos de gestão empresarial (VICTOR,1997).

Essa mudança de paradigma na formação do profissional dentro dos cursos de graduação, ou seja do conteúdo eminentemente técnico, para o técnico e de habilidades é sustentada pela alteração do foco do ensino, para o ensino e aprendizagem a fim de que se consiga continuar alcançando a excelência na preparação profissional nas Instituições de Ensino Superior.

\subsection{Paradigmas e o Contexto Educacional}

A aprendizagem para que seja efetiva deve ser significativa e isso significa estar em conformidade com a situação atual enfrentada pelas pessoas envolvidas no processo, capacitando-os a aplicar o que foi aprendido em situações variáveis e semelhantes (LOGAREZI, 1996)

Segundo MARTINS (1990: p.154), "o professor tem um compromisso mais restrito" (...) "transmitir certo conteúdo de conhecimentos relativos à sua disciplina. O educador, por sua vez, é aquele de quem se recebe exemplo e lição de vida. $O$ educador não precisa ser, necessariamente, um professor, mas se o for, possui um compromisso mais amplo com o educando, isto é, além de transmissão de 
conhecimentos, sua presença demonstra ao educando que esse conhecimento tem um sentido transcendental".

A importância dessa nova postura dentro do ensino de graduação direciona a reavaliação de todo processo, do início (idealização curricular) ao fim (sala de aula). Essa proposição chega a ser comprovada pelas constantes intervenções ocorridas pelo Ministério da Educação e Cultura (MEC) (provão, avaliação curricular, etc.) e pelas pessoas diretamente envolvidas, com educadores assumindo uma postura de constante atualização.

Segundo PETERSON (1998), a criação e a adoção de novos padrões de ensino e aprendizagem podem ser considerados com um marco histórico em direção à inovação e melhoria contínua no ensino de Engenharia e todo processo é iniciado a partir da consciência da amplitude das estratégias em direção à aprendizagem que são utilizadas para efetivar seus planejamentos de ensino.

O conteúdo técnico da profissão sempre foi tratado com total qualidade, por várias Instituições de Ensino Superior que com isso, suprem o mercado com profissionais capacitados tecnicamente. Mas, o desempenho profissional não tem como única variante o conhecimento técnico. Torna-se importante conhecer o que mais se faz necessário para a inserção no mercado de trabalho e adaptar o trabalho do educador a estes novos parâmetros.

Esta adaptação às mudanças já é uma característica pessoal desenvolvida por muitos profissionais da área acadêmica, por estarem atentos às novidades técnicas e incorporá-las a suas práticas didáticas.

Ao assumirem disciplinas novas que não conhecem, tão profundamente, os conceitos técnicos relacionados a ela, educadores são capazes de utilizar suas experiências anteriores para construírem um novo modelo de conhecimento e planejarem o processo de ensino e aprendizagem de uma forma coerente. Ou seja, utilizam habilidades adicionais às técnicas existentes para construírem um novo padrão de transmissão de conhecimento.

Essa habilidade de adaptação, de aprender a aprender, de transmitir, seja textual ou oral, o conhecimento adquirido, de abstrair conceitos relacionados, são 
algumas das capacidades que devem ter todos os profissionais que queiram atuar no mercado de trabalho, independentemente da área de atuação.

Não há mais tempo para que somente o mercado de trabalho e a necessidade desenvolvam estas características adicionais nos indivíduo, as universidades devem participar, de forma efetiva, nesse processo.

Nesse contexto, as Instituições de Ensino Superior devem estar atentas para enfatizar, além do desenvolvimento do modo científico do pensamento, o desenvolvimento de características específicas (WENK,1998).

Mudança de conteúdos de aspectos eminentemente técnicos apenas são necessários de acordo com a evolução do próprio assunto a ser tratado pela disciplina. O diferencial está na ampliação do alcance pedagógico quanto a mudanças de atitudes e posturas, ou seja, aquilo que ajudará a formar no indivíduo a base para a sua conduta profissional.

Segundo LOGAREZZI (1996: 38) "vivemos hoje um momento especial na comunidade ligada à Área de Engenharia, quando se pretende que os cursos passem a formar profissionais que consigam compreender e lidar com as novas condicionantes da realidade (científica, tecnológica, mercadológica, psicossocial, etc.) e que, ao mesmo tempo, venham a se inserir no novo contexto mundial com personalidade e independência".

E essa inserção no contexto mundial tem como vínculo o máximo desenvolvimento do potencial humano. 


\subsection{Potencial Humano - Uma Visão Histórica}

Durante muito tempo, os estudos sobre o potencial humano e o desenvolvimento das habilidades humanas foram abordados apenas em pesquisas relacionadas à área de psicologia. Hoje, esse tema é discutido nas mais diferentes áreas, incluindo educação, assim como seu relacionamento e implicações ao uso do conhecimento específico em diferentes culturas e as potencialidades humanas (GARDNER,1997).

No mundo todo, pessoas relacionadas à educação estão chegando a conclusões semelhantes sobre o que é o desenvolvimento do potencial humano, que chega a ser definido como: treinar indivíduos em habilidades gerais como "aprender a aprender", adequar-se ao um mercado profissional em constante atualização, assimilar, sem grandes dificuldades, toda mudança socioeconômica e cultural ocorrida, dentre outras.

Durante bem mais de dois mil anos, determinados conjuntos de idéias dominaram as discussões sobre a condição humana em nossas civilizações. Essa coletânea de idéias enfatizava a existência e a importância de poderes mentais - capacidade que foram diferentemente denominadas de racionalidade, inteligência, habilidade, desenvolvimento da mente, capacidade intelectual - na nossa sociedade (GARDNER,1997).

O conhecimento e a capacidade de utilização desses sempre foram destacados e valorizados. Seja filósofos, educadores ou cientistas, o indivíduo capaz de usar seus poderes mentais sempre foi motivo de admiração e de automotivação para o desenvolvimento pessoal e de civilizações, reforçados por frases como "Conhece-te a ti mesmo", de Sócrates; "Todos os homens por natureza desejam o saber", de Aristóteles e o "Penso logo existo", de Descartes (RIBEIRO, 1998).

Parafraseando Santo Agostinho, considerado o próprio pai da fé, GARDNER (1994: p. 4) diz que: "o primordial autor e motor do universo é a inteligência. Portanto, a causa final do universo dever ser o bem da inteligência e 
isto é verdade... De todas as buscas humanas, a busca da sabedoria é a mais perfeita, a mais sublime, a mais útil e a mais agradável."

Neste contexto, a busca pela "definição" de inteligência, potencial humano sempre esteve presente, e em cada momento, diferentes definições eram encontradas.

No século XVII com a didática, fundada por Comênio, misturando os meios realistas com os fins espirituais, foi concebido um sistema escolar para crianças de 06 a 12 anos, para o desenvolvimento da inteligência, da imaginação e da memória em conjunto com os órgãos sensoriais e a fala, mas foi só a partir do século XVIII a ciência se separa da religião (fins espirituais) em busca de uma nova definição, tendo o desenvolvimento científico como base. (PASSARELLI, 1996).

Com o desenvolvimento científico contrastando com desenvolvimento do subjetivo aceito até então, começam a se desenvolver diferentes pesquisas relacionadas ao desempenho mental e ao desenvolvimento sociocultural do homem, sempre a procura de respostas sobre uma melhor forma de desenvolvêlos (educá-los).

Franz Joseph Gall, médico e cientista, em seu estudo científico observou e relacionou o desempenho mental de diferentes áreas (emoção, procriação, discrição, auto-estima, poderes reflexivos, capacidades perceptivas incluindo a linguagem, afinação (música), sensibilidade pra propriedades para cor, dentre outras) com o tamanho físico do crânio. Ele apegou-se a esta idéia instituindo uma nova disciplina na área da medicina chama "frenologia" (GARDNER, 1994).

A idéia chave da frenologia é simples. Os crânios diferem um dos outros e suas variações refletem diferenças no tamanho e na forma do cérebro, como diferentes áreas do cérebro servem a funções distintas, um especialista seria capaz de determinar os pontos fortes, as fraquezas e as idiossincrasias de seu perfil mental. Gall propôs também que não existem poderes mentais gerais como percepção, memória e atenção, mas, sim, diferentes formas de percepção, de 
memória e similares para cada uma das várias faculdades como linguagem, música ou visão (PASSARELLI, 1996).

Hoje se sabe que a proposta de Gall é falha, mas durante sua pesquisa ele propôs outras idéias como não há poderes mentais gerais como percepção, memória e atenção; mas antes, há diferentes formas de percepção, memória e similares para cada uma das diversas faculdades intelectuais, como linguagem, música, visão, e isso foi uma grande colaboração para as novas pesquisas (FORGATY,1997).

Os séculos que se seguiram às proposições de Gall foram marcados por repetidas tentativas de se correlacionar cérebro e comportamento e descobrir as raízes físicas de atividades mentais. Os egípcios localizavam o pensamento no coração, Pitágoras e Platão sustentavam que a mente encontrava-se no cérebro, Aristóteles pensou que a sede da vida está no coração, Decartes colocou a alma na glândula pineal, dentre outros (HAPPE,1997)

Todas as pesquisas surgidas até então relacionavam de alguma forma a inteligência ligada à patologia clinica, foi no começo do século XIX, que houve esta dissociação objetivo/subjetivo e a psicologia (voltada para o indivíduo) e a sociologia (voltada para o social) teve sua importância reconhecida. (GARDNER1997).

Os cientistas do século XIX não foram os primeiros a tentar separar a gama de habilidades intelectuais humanas, mas sua inovação se deve ao fato de terem introduzido proposições altamente específicas sobre o perfil das capacidades mentais humanas, ou seja, desenvolveram esforços empiricamente fundamentados no laboratório clínico e experimental relacionando áreas especificas do cérebro às funções cognitivas específicas, com isso a educação com a finalidade de trabalhar a "inteligência" do indivíduo obteve grande contribuição.

Nesse contexto histórico, observa-se que a palavra "inteligência" como sinônimo de potencial humano foi usada, por algumas pessoas, apenas para designar a capacidade que possuem, ligando esta característica ao meio cultural 
ao qual pertence Muitas pessoas foram denominadas inteligentes ou não apenas por possuírem ou não habilidades específicas.

\subsection{Contribuições para a Definição de Inteligência Humana}

Com o surgimento da psicologia pré-científica relacionada à filosofia negando todo seu relacionamento com a medicina, muitos esforços foram realizados a favor do desenvolvimento humano enfocando apenas o processo filosófico e existencial presentes no processo (GARDNER,1994; PASSARELLI,1996).

A psicologia realizou muitas de suas pesquisas pelas "leis de faculdades mentais horizontais" - capacidade como memória, percepção, atenção, associação e aprendizagem, distantes de experimentos e pesquisas relacionados à ciência do cérebro (PAPERT,1994)

Assim, a psicologia científica procurou pelas leis mais gerais do conhecimento humano as diferenças individuais. Baseado nestas premissas de diferenças individuais, o médico e cientista Sir Francis Galton, interessado por indivíduos denominado "gênios", desenvolveu métodos estatísticos que possibilitavam classificar os seres humanos em termos dos seus poderes físicos e intelectuais e a correlacionar estas medidas entre si (GARDNER,1994; PEREIRA,1999).

A partir do estudo de Galton, vários psicólogos desenvolveram vários testes e começaram a classificar os seres humanos comparando seus desempenhos a valores relacionados nestas medições; testes estes que abordaram tarefas de discriminação sensorial e habilidade de distinguir entre sons, luzes ou pesos. Estes testes foram de grande valia para a ciência, mas eram limitados em relação às habilidades medidas.

Gradualmente a comunidade científica concluiu que seria necessário observar principalmente capacidades mais complexas que envolviam linguagem e a abstração, para obter avaliações mais precisas. Foi neste panorama que o 
francês Alfred Binet e seu colega Théodore Simon, atendendo a um pedido dos ministros de Paris, no final do século XVIII, desenvolveram os testes de medição do quoeficiente de inteligência (GARDNER,1994; PAPERT, 1994).

Os testes desenvolvidos por Binet, aplicados primeiramente como medida para identificar pessoas com deficiências de aprendizagem nos primeiros anos escolares, foram prontamente utilizado no estado da Califórnia, USA, com o propósito de classificar indivíduos de acordo com sua "habilidade mental". Entre os anos de 1920 e 1930, estes testes foram amplamente aplicados e divulgados por todo o mundo.

Dentro da comunidade científica e na sociedade, o entusiasmo sobre a testagem da inteligência foi tão grande que logo, tarefas e testes, estavam à disposição para o uso e a "mania de avaliar pessoas para propósitos específicos", foi amplamente utilizada.

Até pouco tempo, muitos psicólogos concordariam com a avaliação de que a testagem da inteligência era uma das maiores conquista da psicologia; hoje, muitos já estão convencidos de que este entusiasmo pode ter sido excessivo, e que há inúmeras limitações nos próprios instrumentos e na maneira como foram utilizados.

Os testes que mediam o Quoeficiente de Inteligência Humana, QI, foram amplamente utilizados dentro da sociedade escolar e não levavam em considerações antecedentes socioeconômicos.

Em muitos momentos pesquisadores alegaram que este quoeficiente de inteligência (QI) era um fator hereditário mas nunca, nada, foi comprovado cientificamente.

Os testes foram amplamente utilizados em diversas áreas de conhecimento e em muitas delas, de acordo com os parâmetros utilizados para a análise matemática dos dados, resultados diferentes eram obtidos.

Por volta de 1920, enquanto os testes de medição de inteligência estavam no auge, o suíço Jean Piaget, indivíduo "treinado" dentro da tradição de medição 
de inteligência, e trabalhando dentro do laboratório de Binet, tornou-se particularmente interessado nos erros que as crianças cometiam quando tentavam resolver alguns itens num teste de inteligência e percebeu que crianças de mesma idade cometiam erros similares. Iniciou um trabalho na averiguação destes erros objetivando descrever a linha de raciocínio do indivíduo. Para ele era mais importante a linha de raciocino que a criança evocava do que a precisão da resposta (GARDNER, 1994).

Embora suas pesquisas comprovavam a ineficiência dos testes de QI, Piaget jamais criticou os testes, simplesmente adicionou novas variáveis a serem observadas.

O movimento dos testes de QI é empírico - fundamenta-se simplesmente em testes com algum poder preditivo do sucesso escolar, não há questões de como a mente funciona ou como mediar alguns limites de raciocínio, apenas a questão de uma pessoa chegar ou não a uma resposta correta.

Grandes partes das informações investigadas em testes de QI refletem conhecimento adquirido pela vivência num determinado meio social e educacional, eles raramente avaliam a habilidade de assimilar informações novas, resolver problemas novos, ou sobre seu potencial (PAPERT, 1997).

Esta tendência em direção ao conhecimento "cristalizado" ao invés do "fluído" pode ter conseqüências extraordinárias. Foi, cientificamente comprovado, que um indivíduo pode perder seus lóbulos frontais inteiro, tornar-se uma pessoa radicalmente diferente das ditas "normal", incapaz de demonstrar qualquer iniciativa ou resolver problemas novos e ainda, ao ser testado, continuar a apresentar QI próximo ao nível de um gênio, simplesmente porque aquilo foi "assimilado" (GARDNER,1994).

Piaget considerou muitas variáveis que os testes de QI não levaram em consideração (como o exemplo acima) e desenvolveu um poderoso trabalho em direção a cognição humana, criando novos testes, e o processo de ensino e aprendizagem obteve uma grande contribuição destes estudos. Ele considerava 
que o indivíduo está constantemente construindo hipóteses e por meio disso tentando gerar conhecimento.

Pelo fato de considerar fatores antes desconsiderados, Piaget se tornou "o teórico do desenvolvimento cognitivo" (PAPERT,1997).

Embora muito dos contornos do desenvolvimento esboçado por Piaget permaneçam válidos, muitos dos detalhes específicos da sua teoria são contestados e, mesmo sendo considerado um dos melhores modelos de desenvolvimento mental existente, suas deficiências estão sendo evidenciadas, a cada dia, com as novas pesquisas e com a inassimilação de assuntos relacionados às atividades acadêmicas, são os melhores profissionais do mercado.

Analisando as abordagens Piagetiana e dos testes de medição do quoeficiente de inteligência há a evidência da focalização em determinado tipo de resolução de problemas lógicos ou lingüísticos; sendo que todos ignoraram as ciências biológicas e a importância dos símbolos, que foram considerados a chave na evolução da natureza humana por muito tempo.

Segundo GARDNER et al (1998), ao se considerar a importância dos símbolos e da biologia durante a evolução mental de um indivíduo estará se observando a importância dos domínios culturais na definição de limites e conquistas individuais.

No contexto de levar em consideração os domínios culturais, durante o desenvolvimento mental do indivíduo, e suas influências diretas no processo de ensino e aprendizagem, David Feldman, Gabriel Salomon e David Olson, são nomes que se destacam e que tiveram grande influência no desenvolvimento de uma teoria que relacionaria a inteligência a todos os fatores presentes no dia a dia das pessoas (GARDNER, 1994).

No discurso pedagógico, junto com expressões como teste de inteligência, indivíduos inteligentes, falta de inteligência, inteligência brilhantes, encontram-se cada vez mais outras como: inteligência artificial, sistemas inteligentes, inteligências múltiplas, tecnologia da inteligência, que apresentavam, 
naturalmente, pontos de contato com as anteriores, mas que sugerem com muito vigor outros núcleos de significação em direção ao perfeito e mais completo desenvolvimento sócio-economico-educacional-cultural do indivíduo (MACHADO, 1995).

Esses são mais indícios de que a consideração de inteligência como uma grandeza passível de medição, quase sempre associada ao conhecidos testes de inteligência, ou como uma única competência individual - a capacidade de raciocinar ou compreender algo já não é mais considerável em sua totalidade.

\subsection{Pluralização do Conceito de Inteligência}

Enquanto inteligência foi inicialmente percebida como um conceito unitário que poderia ser definida através de um número, um grande número de estudos foi desencadeado com objetivo de comprovar se este conceito "unitário" poderia ser dividido em várias partes. L.L. Thurstone e J.P. Guilford apud DICKINSON (1997) desenvolveram uma teoria objetivando a comprovação de que a inteligência era mais bem compreendida se observada como um conjunto de possibilidades, formada por fatores independentes.

Indecentemente das pesquisas procuravam comprovar que a inteligência era singular ou pluralista, a definição dela como uma capacidade que poderia ser desenvolvida e aprimorada é recente.

Como a definição da inteligência e suas implicações está diretamente relacionada ao processo educacional, GARDNER (1993) analisou a sociedade americana e constatou que a concepção de inteligência encontrava-se derivada por grandes preconceitos que dificultava o bom funcionamento das instituições de ensino.

O mais comum dentre os preceitos existente, denominado westismo, consistiria em reduzir-se o significado do pensamento, da racionalidade, do quadro de valores, ao universo ocidental, de fundamentação aristotélica e natureza lingüístico-lógico-matemática, ignorando-se ou subestimando-se outras formas de 
associação de idéias. Tal predisposição condiciona, naturalmente, a caracterização dos indivíduos "inteligentes", excluindo ou subvalorizando competências ideográficas, que predominam na cultura oriental (MARTINHO,1994; MACHADO,1995).

Einstein foi vítima do westismo; ele descrevia que as palavras ou linguagem, como eram escritas ou faladas, não pareciam desempenhar qualquer papel no seu mecanismo de pensamento, ao contrário seu pensamento era "cheio" de imagens mentais que após serem assimiladas podiam ser manipuladas de qualquer forma, devido a isso foi um aluno não muito bem visto durante sua fase escolar, porque sua "inteligência" não encontrou canais adequados para se manifestar dento daquele ambiente (MACHADO,1995).

Hoje em dia, já se sabe que inteligência não pode ser contextualizada ou medida com eficiência, sem levar em consideração o ambiente, a cultura e a sociedade em que o indivíduo vive, trabalha, participa e as oportunidades e valores providos pelo meio.

Considerando todas as posições existentes, Howard Gardner, psicólogo e professor da Harvard School of Education, começou um estudo científico de análise do desenvolvimento do potencial humano em crianças normais e em crianças ditas superinteligentes, e da perda das capacidades cognitivas em indivíduos que sofriam de um mau funcionamento cerebral.

Levando em consideração estes tipos de indivíduos, no Hospital Escola da Universidade de Boston (Boston /Veterans Administration Medical Center), junto com alguns pesquisadores e da Escola de Medicina da Universidade de Boston (Boston University School of Medicine) desenvolveu uma teoria, que leva em consideração a pluralidade das capacidades humanas, que ele chamou de "inteligências múltiplas", construída a partir da comparação entre os testes de QI e do desempenho humano de diferentes tipos de pessoas e suas relações com os vários sistemas simbólicos (escrita, imagem, etc) e científicos (pesquisas neurológicas) existentes (BARKMAN, 1997). 
CApítulo 6

\section{TEORIA DAS INTELIGÊNCIAS MÚLTIPLAS}

O quociente de inteligência (QI) e o modo como era utilizado meio para medição da inteligência - teve indiscutivelmente sua contribuição positiva nos meios científicos, acadêmicos e profissionais, mas agregado às vantagens veio a conseqüência de exercer um considerável efeito sobre a futura predisposição do um indivíduo à aprendizagem e ao seu desenvolvimento, dependendo do resultado alcançado. Determinado o valor do quociente de inteligência e comunicado à pessoa que havia se submetido ao teste, era como se a este valor fosse agregado um "destino".

Através desse valor era "determinado" o modo como educadores, colegas, pais, e até mesmo ele próprio deveria ser tratado e qual seria o máximo a ser alcançado por ele dentro do processo de aprendizagem.

A importância vinculada ao valor não é inteiramente inadequada. Afinal, o escore em um teste de inteligência de fato prevê a habilidade da pessoa em relação às matérias escolares mas não prevê sobre seu desempenho como pessoa, na vida além da acadêmica (GARDNER,1994).

Através da existência dessa lacuna entre o sucesso em assimilar matérias escolares e sucesso na "vida pessoal e profissional" do 
indivíduo, percebeu-se que inteligência era um conceito muito mais amplo do que o previsto nos testes de QI.

Dessa forma, verificou-se que quando mais se expande e reformula-se a concepção do que se conta como intelecto humano inteligência e desempenho, mais fácil se torna projetar meios eficazes para avaliar e aprimorar o indivíduo como um todo.

A Teoria das Inteligências Múltiplas é uma nova teoria de competências intelectuais humanas. Ela desafia a visão clássica da inteligência que muitos assimilaram explicitamente pela psicologia ou através dos testes de educação ou implicitamente - vivendo numa cultura com uma concepção forte, mas possivelmente circunscrita, de inteligência (SMOLE,1996).

Com o desenvolvimento dos estudos sobre a pluralização da inteligência e fatos comprovantes de que nem sempre o melhor aluno da classe é o melhor profissional, houve a constatação de que desempenho pessoal escolar e profissional vai além da capacidade de assimilação de conteúdos proposta pelos meios acadêmicos.

Nesse contexto, houve o desenvolvimento de várias teorias e dentre elas a elaborada pelo Prof. Dr. Howard Gardner, que concebeu uma nova e diferente visão sobre as competências intelectuais humanas, baseando-se em muitos anos de pesquisa em psicologia cognitiva e neuropsicológica, levando em consideração a influência e a quantidade de informações existentes no contexto social, econômico e cultural em que a pessoa vive.

As pesquisas realizadas por Gardner tiveram início quando uma instituição ${ }^{1}$ internacional Holandesa, que apóia projetos inovadores na área de educação, solicitou, em 1979, que se avaliasse o estado do

\footnotetext{
${ }^{1}$ Bernard van Leer Foundation de Haia, na Holanda: instituição internacional não lucrativa dedicada à causa das crianças e jovens desprivilegiados, que apóia projetos inovadores que desenvolvem abordagens comunitárias em educação para ajudar crianças com dificuldades a atingirem seu potencial.
} 
conhecimento científico referente ao potencial humano e à sua capacidade de desempenho.

Um grupo de estudiosos engajou-se em pesquisas que exploram a natureza e o desenvolvimento do potencial humano dando origem a um projeto conhecido internacionalmente como Projeto Zero ${ }^{2}$.

Nesse projeto foi incluída uma revisão da literatura relevante de história, filosofia, ciências sociais, naturais e biológicas para contextualizar o "intelecto humano e a capacidade de desenvolvimento" que posteriormente seria chamado de "potencial de inteligência".

Howard Gardner é um dos responsáveis pelo projeto, que utilizou seu conhecimento como psicólogo estudando o desenvolvimento e as habilidades simbólicas de indivíduo ditos "normais" e "talentosos" (superdotados) e a diminuição destas habilidades em pessoas com algum dano cerebral.

Foi no Projeto Zero que foi divulgado no meio científico a primeira idéia oficial e cientifica sobre a pluralização da inteligência - Inteligências Múltiplas.

Várias pessoas de diferentes áreas de atuação desenvolvem o projeto, cuja pesquisa foi bem assimilada e facilmente aceita nos meios científicos e acadêmicos (SMOLE ,1996).

Fazem parte da equipe do projeto: um educador, um psicólogo desenvolvimental, um profissional da criação de programas educativos; um filósofo com experiência na área de educação, filosofia da ciência e da linguagem, um antropólogo especializado em vida familiar, cuidado infantil e desenvolvimento psicológico e uma socióloga especialista em assuntos nipônicos que estudou educação, organizações formais e os papéis das mulheres no terceiro mundo (GARDNER,1994; GARDNER,1996).

Neste contexto, com tantos profissionais de áreas diferentes, trabalhando com objetivos comuns e a ampla gama de interesses e

\footnotetext{
${ }^{2}$ Projeto Zero: projeto desenvolvido, aprimorado até hoje, sobre o potencial Humano
} 
disciplinas envolvidas, capacitou-se o Projeto a adotar uma abordagem multifacetada em relação às questões do potencial humano, denominada Teoria das Inteligências Múltiplas.

Coube ao professor Dr. Howard Gardner o desenvolvimento, a liderança da pesquisa e a divulgação de suas descobertas no meio científico e acadêmico, por isso hoje é reconhecida como Teoria das Inteligências Múltiplas de Howard Gardner (GARDNER,1998; RIBEIRO, 1998).

Durante a pesquisa, houve a revisão de evidências de um grande e não relacionado grupo de indivíduos: prodígios $^{3}$, indivíduos talentosos, pacientes com danos cerebrais, idiots savants ${ }^{4}$, crianças e adultos ditos "normais" (fisiologicamente) (GARDNER , 1997).

Com uma amostra diversificada, pertencente a diferentes culturas e com especialidades, procurou verificar a relação e existência de uma habilidade comum (inteligência) que poderia ser encontrada ou diagnosticada ausente, ou presente, de forma autônoma, e a possibilidade de desenvolvê-la (GARDNER, 1994; GARDNER, 1997).

Dessa forma pesquisadores experimentais e/ou especialistas em disciplinas específicas postularam o que chamaram de habilidades centrais, que, de fato, definem inteligência, com um espectro de habilidades e capacidades, não necessariamente conectadas entre si, mas que trabalhem em harmonia (GARDNER et all,1998).

Para chegarem a definição da pluralidade da inteligência, todas as definições de inteligência e meios de cognições humanas foram pesquisadas e estudadas (MACHADO,1995).

\footnotetext{
3 Prodígio: indivíduo precoce em uma, ou ocasionalmente mais que uma, área de conhecimento, de competência humana. que parece torná-lo qualitativamente diferente de outros indivíduos.

${ }^{4}$ Idiots savants, indivíduo que possui algum tipo de deficiência patológica (autista) e mesmo assim, uma habilidade humana particular é poupados integralmente contra vários domínios de desempenhos humanos medíocres ou alternamente retardados.
} 
Esta pesquisa envolveu tanto os relacionamentos a nível comportamental como os fisiológicos e está constantemente sendo reavaliada pelos integrantes do projeto.

“(...) Com revisões de pesquisas recentes sobre neurobiologia novamente foi constatada que a presença de áreas no cérebro correspondem, pelo menos aproximadamente, a determinadas formas de cognição; e estes mesmos estudos implicam numa organização neural que prova ser hospitaleira a noções de diferentes modos de processamento de informações. (...)".

(...) Mas a ciência jamais pode proceder de forma completamente indutiva. Poderíamos realizar todos os testes e experiências psicológicas concebíveis ou esquadrinhar toda a instalação neuroatômica que desejássemos e ainda assim não teríamos identificado as procuradas inteligências humanas. Aqui, nos confrontamos com uma pergunta não sobre a exatidão do conhecimento, mas, antes, sobre como o conhecimento é obtido. É necessário avançar uma hipótese ou uma teoria e então testá-la. Apenas quando os pontos fortes - e limitações da teoria tornam-se conhecidas à plausibilidade do postulado original torna-se evidente" (GARDNER, 1994:45).

Como nenhuma ciência jamais produz uma resposta completamente final e correta sobre a inteligência humana, as inteligências propostas, hoje numeradas em nove diferentes tipos, jamais terão sua quantidade definida como um número definitivo. (GARDNER, 2000) Poderia haver aproximação de um número definitivo se as pesquisas se mantivessem apenas em um nível de análise neurofisiológica ou como uma meta de previsão de sucesso numa universidade técnica, mas ao se buscar uma teoria incisiva sobre o alcance da inteligência humana, e no seu desenvolvimento, objetivando o desenvolvimento técnico, comportamental e social do indivíduo este número poderá ser incrementado. 


\subsection{Pré-requisito para ser Considerada uma Inteligência Dentro da Teoria das Inteligências Múltiplas}

GARDNER (1983) escolheu a palavra inteligência para que psicólogos e pedagogos entendessem melhor sua pesquisa, uma vez que esses profissionais, muitas vezes, consideravam a habilidade lógica e a linguagem como fator determinante de inteligência; e, a música e esportes como aptidões de grande simpatia dos testes de inteligência, pela importância acentuada na cultura ocidental. Portanto, trata-se de uma questão de terminologia.

$\mathrm{Na}$ Teoria das Inteligências Múltiplas ${ }^{5}$, inteligência é a capacidade de resolver problemas - capacitando o indivíduo a resolver situações ou dificuldades específicas encontradas - devendo apresentar potencial para encontrar ou criar novos problemas, propiciando um novo ciclo de raciocínio - o lastro para a aquisição de conhecimentos novos; tudo isso levando em consideração a realidade cultural e social de cada indivíduo.

É importante frisar que não importa o tipo do problema a ser resolvido, se é um cálculo, um raciocínio ou um objeto difícil de ser acessado, se o indivíduo conseguir ter sucesso, seja lá qual for à situação, ele já é considerado portador de uma inteligência que poderá ser aprimorada (HO e LU,1996).

Os requisitos que definem uma competência é o meio de assegurar que, ao se considerar uma inteligência humana, ela deve ser genuinamente útil e importante, dentro do contexto social, educacional, profissional, econômico e cultural em que está inserida (RIBEIRO,1998; HO e LU,1996; GARDNER, 1996).

Ao definir as inteligências existentes, GARDNER (1994) procurou relacionar competências que captassem uma gama razoavelmente

\footnotetext{
${ }^{5}$ É no nível de definição que a Teoria das Inteligências Múltiplas diverge dos pontos de vistas tradicionais, que definem inteligência como a capacidade de responder ou não a determinados estímulos específicos.
} 
completa de tipos de habilidades valorizadas pelas mais diferentes culturas e que satisfizessem determinados critérios científicos.

A Teoria das Inteligências Múltiplas é elaborada à luz das origens biológicas de cada capacidade de resolver problemas. Somente são tratadas aquelas capacidades que são universais na espécie humana. Mesmo assim, a tendência biológica a participar numa determinada forma de solução de problemas também deve ser vinculada ao estímulo cultural nesse domínio. Por exemplo, a linguagem, uma capacidade universal, pode manifestar-se particularmente como escrita em uma cultura, como oratória em outra, e como a linguagem secreta dos anagramas em uma terceira (GARDNER, 1995:21).

GARDNER (1984), ao criar a lista das inteligências, procurou usar critérios que tivessem raízes na biologia e que fossem realmente valorizados em culturas diferentes.

Segundo GARDNER et all (1996) só são reconhecidos como inteligências aquelas habilidade que foram comprovadas de acordo com critérios estipulados:

1) ISOLAMENTO POR DANOS CEREBRAL - ocorrendo um dano cerebral, irreversível, uma habilidade deverá ser capaz de comprovar a autonomia, em relação a outras faculdades humanas;

2) INDEPENDÊNCIA GENÉTICA E BIOLÓGICA - utilizando como amostras indivíduo denominados ldiots Savants, Prodígios e indivíduos excepcionais, houve a possibilidade de estudar isoladamente habilidades e comprovar sua relação de independência genética e a determinada região neural específica;

3) COMPROVAÇÃO DA PERTINÊNCIA A CENTROS NEURAIS AUTÔNOMOS - a identificação de uma operação central, localizada no substrato neural e a possibilidade de comprovação que este 'centros' são autônomos se dá pelo fato de que havendo uma lesão fisiologia, há a possibilidade do surgimento de um desempenho intelectual diferente ou até de uma inexistente; 
4) Pertencer À históRia desenvolvimental distintiva aliada A UM CONJUNTO DEFINÍVEL DE DESEMPENHOS - uma inteligência para ser comprovada deverá ter uma história desenvolvimental identificável, através da qual, tanto indivíduos normais quanto talentosos, passam no decorrer da ontogenia ${ }^{6}$. Como uma inteligência não se desenvolverá isoladamente é necessário que sua história desenvolvimental possa ser estudada e comprovada;

5) TER UMA HISTÓRIA E SUA PLAUSIBILIDADE EVOLUTIVA - ser capaz de relacionar a evolução da inteligência (ou ignorância) de acordo com a sua correlação com a evolução da sociedade em que está inserida o indivíduo;

6) APOIO DE TAREFAS PSICOLÓGICAS EXPERIMENTAIS - através da utilização de critérios e paradigmas relacionados à psicologia experimental pode comprovar a ausência ou existência de capacidades específicas utilizando os testes de medição do quociente de inteligência;

7) TESTES psicomÉtRICOS - os processos e métodos de testagem de inteligência são relevantes na comprovação das mesmas à medida que são utilizados para comprovar qualquer um dos critérios citados;

8) SuscetibilidAde À CODIFICAÇÃo EM UM SISTEMA SIMBÓliCO linguagem, desenho e matemática são apenas 3 dos sistemas simbólicos que se tornaram importante no mundo inteiro para a sobrevivência e produtividade humana, portanto, uma característica principal para uma inteligência humana é sua gravitação "natural" em direção em um sistema simbólico.

Estes são os critérios pelos quais as inteligências podem ser julgadas ou comprovadas dentro do contexto científico da teoria, embora Gardner não rejeite o posicionamento de alguns companheiros de pesquisas que dizem que a rejeição ou não de uma inteligência candidata

${ }^{6}$ Ontogenia: Desenvolvimento do indivíduo desde a fecundação até a maturidade para a reprodução. 
é mais uma questão de posicionamento e interpretação de alguns desses critérios, mas, para que isso não ocorra, os critérios foram tornados públicos para que novos pesquisadores possam estar estudando-os e propondo novos critérios, inteligências, ou questionando algumas das já definidas.

\subsection{Tipos de Inteligências - Teoria das Inteligências Múltiplas}

As 9 inteligências presentes na Teoria das Inteligências Múltiplas, comprovadas pelos critérios relacionados são:
a) Lingüística
b) Musical
c) Matemática /Lógica
d) Cinestésica /Corporal
e) Espacial
f) Pessoais $-\left[\begin{array}{l}\text { Interpessoal } \\ \text { Intrapessoal }\end{array}\right.$
g) Naturalista
h) Existencial

\subsubsection{Inteligência Lingüística}

"Inteligência lingüística - capacidade de lidar bem com a linguagem, tanto na expressão verbal quanto escrita. Competência esta verificada nos escritores, oradores, políticos, professores, etc." (RIBEIRO,1998, p.6)

A linguagem é considerada um exemplo preeminente da inteligência humana. (SMOLE,1996) Seja pra escrever alguma coisa ou 
para vencer um desafio verbal, a opção precisa das palavras prova o quão ela é importante. Na nossa sociedade ela chega a ser considerada como o melhor meio para executar negócios, tarefas, comunicar acontecimentos, etc.

Todas as pessoas de todas as culturas possuem habilidades de articular linguagens, mas há diferenças entre as pessoas. Enquanto algumas não conseguem passar da habilidade básica de comunicação, alguns aprendem com facilidade vários idiomas, isso comprova que todos são susceptíveis a estas características em graus diferenciados e significativos.

Fisiologicamente, existem pesquisas que mostram que determinada lesão cerebral pode fazer com que pessoas percam habilidade de articular a fala e a escrita, embora a compreensão de vocabulários e sintaxe, permaneçam intactas (GARDNER,1995).

A habilidade de construir e compreender uma determinada linguagem pode variar. Surdos-mudos, pessoas normais, pessoas com deficiências variadas possuem seus próprios meios para compreensão, mas, cognitivamente, o tratamento da linguagem é o mesmo, ele é universal (MORGAN,1998).

Algumas pessoas possuem esta habilidade diferenciada, como é caso dos poetas e escritores que conseguem enxergar com clareza as operações centrais da linguagem.

Possuem uma sensibilidade ao significado das palavras, à sua ordem, à capacidade de seguir regras gramaticais, e em algumas ocasiões, conseguem, cuidadosamente, ignorá-las.

Também a nível sensorial, algumas pessoas possuem uma sensibilidade ao som, ao ritmo, a reflexões e até ao tamanho das palavras. Trata-se da habilidade agradável de ouvir um outro idioma e, mesmo sem entendê-lo, achá-lo "bonito" pelo som que as palavras emitem. As pessoas com estas características possuem a inteligência lingüística bem desenvolvida (GARDNER,1998). 
"A competência lingüística é, de fato, a inteligência - a competência intelectual - que parece mais ampla e mais democraticamente compartilhada na espécie humana" (GARDNER, 1994:61).

Dentro do ramo da neuropediatria, o neurocirurgião e pesquisador Harry Chugani, professor da Universidade de Wayne, nos Estados unidos, realizou algumas experiências com crianças e constatou que as primeiras experiências de vida de um ser humano podem mudar por completo a maneira como as pessoas desenvolvem a articulação de uma linguagem.

As experiências e os estímulos são fundamentais no processo de desenvolvimento do cérebro, pois estes "exercícios" propiciarão ligações entre os neurônios, ocorrências diretamente ligadas à idade cronológica do indivíduo; a esta definição científica deu-se o nome de "janelas de oportunidades", ou seja, para o desenvolvimento de certas habilidades existem épocas propícias e férteis, dentre as "janelas de oportunidades". A primeira a ser "aberta" é a da linguagem, que se inicia no nascimento (RIBEIRO,1998).

O fato de existirem fases propícias para desenvolver determinadas habilidades - trabalhar em equipe, falar, praticar determinado tipo de esporte ou instrumento - não significa que não se possa aprimorá-las durante toda a vida; a diferença é que, se uma pessoa teve estes estímulos nas idades propícias, haverá maior predisposição para melhorála na vida adulta.

Segundo GARDNER (1994), a inteligência lingüística, embora seja utilizada para fins específicos (comunicação entre pessoas, idéias,sentimentos, etc.), é utilizada em diferentes momentos, com diferentes propósitos. Dentre eles podemos citar:

$\checkmark$ Convencer pessoas a respeito de um curso de uma ação habilidade que especialistas em direito desenvolvem em alto grau, mas qualquer criança, independentemente da idade já a possui e utiliza-a para ganhar um outro pedaço de doce. 
$\checkmark$ Ajudar a lembrar de outros fatos, regras de jogos, etc.

$\checkmark$ Aprender, dentro do contexto de ensino e aprendizagem, através do uso da linguagem.

$\checkmark$ Pensar sobre a própria linguagem, ou sobre o próprio pensamento - filósofos, lingüístas.

Algumas características presentes em pessoas que possuem inteligência lingüística desenvolvida:

$\checkmark$ Gostar de ler;

$\checkmark$ Gostar de escrever;

$\checkmark$ Entender a ordem e o significado das palavras;

$\checkmark$ Fazer palavras cruzadas;

$\checkmark$ Convencer alguém sobre um fato;

$\checkmark$ Explicar, ensinar e aprender;

$\checkmark$ Contar estórias;

$\checkmark$ Senso de humor;

$\checkmark$ Memória e lembrança aguçada;

$\checkmark$ Análise Metalingüística;

$\checkmark$ Etc.

Esta é, provável, a competência humana mais exaustivamente estudada. As evidências dessa inteligência vêm da psicologia desenvolvimental, que revela uma capacidade para a fala, universal e de rápido desenvolvimento, entre as pessoas normais.

Dentro da neuropsicologia e da neurobiologia sua comprovação foi através dos casos documentados de preservação da fala entre pacientes 
que sofreram dano cerebral e do fato de ajudar a destacar mecanismos ${ }^{7}$ centrais de processamento de informações associados a essa inteligência, respectivamente GARDNER (1998).

\subsubsection{Inteligência Musical}

"Inteligência Musical - capacidade de interpretar, escrever, ler e expressar-se pela música.” (RIBEIRO,1998, p.6).

De todos os talentos com que os indivíduos podem ser dotados, nenhum surge mais cedo do que o talento musical (GARDNER,1998).

Embora a inteligência musical possa não ser tão óbvia para o intelecto, como a inteligência matemática/lógica e/ou lingüística, neurologicamente, a habilidade de atuar e compreender músicas atua independentemente de outras inteligências (RIBEIRO,1998).

Muitas pesquisas na área da psicologia e educação foram realizadas com o intuito de reconhecer padrões cognitivos relacionados à aprendizagem de conceitos ligados à música e estabelecer analogias entre a música e a linguagem humana.

Para GARDNER (1998), embora a competência musical esteja localizada no hemisfério direito do cérebro e a competência lingüística localizada, quase exclusivamente no hemisfério esquerdo em indivíduos destros normais, qualquer dano em um dos hemisférios, apesar de não haver uma conexão concreta, curiosamente, interfere no desempenho correto da outra habilidade. Mas, na crendice popular, a música está mais ligada à habilidade lógico/matemática, por causa dos tempos utilizados. Cientificamente, nada é comprovado.

\footnotetext{
${ }^{7}$ Eles incluem os mecanismos dedicados à fonologia (sons da fala), sintaxe (gramática), semântica (significado) e pragmática (implicações e uso da linguagem em vários ambientes).
} 
Neste contexto, é comprovado que existe uma surpreendente variedade de representações neurais da capacidade musical encontrada nos seres humanos e esta variedade pode auxiliar no desenvolvimento de outras habilidades (GARDNER,1998).

Da ligação da inteligência musical com a matemática, o que se conhece é que de fato a habilidade musical pode ser desenvolvida utilizando alguns conceitos básicos de assimilação matemática, uma vez que algumas interpretações requerem uma sensibilidade à regularidade $\mathrm{e}$ proporções.

Dentre todas as pesquisas existentes em relação à habilidade musical, e suas mais diversas relações com outras habilidades, há um consenso que, independentemente do tipo de pessoa, de sua cultura, todas reconhecem algo de estrutura musical. Ou seja, todas as pessoas são capazes, desde que tenha a capacidade auditiva, de reconhecer sons, agrupá-los, reconhecê-los e reproduzi-los (GARDNER et al.,1998).

Diferentemente da inteligência lingüística, que se desenvolve em alto grau em diferentes culturas, sem instrução formal, uma inteligência musical de alto nível pode exigir uma exposição mais intensiva, um treinamento adequado.

Segundo MILLER $^{8}$ e TREFFERT ${ }^{9}$ apud GARDNER et al. (1998), em estudos sobre os prodígios e savants perceberam que essa inteligência é autônoma em relação a outras capacidades, pois pode manifestar-se num alto nível em uma pessoa cujas outras capacidades são médias ou deficientes.

\footnotetext{
8 MILLER L.K. (1989) Musical Savants: Exceptional skill in the mentally retarded. Hillsdare, NJ, Eribaum.

9 TREFFERT D.A. (1989) Extraordinary People: Understanding 'idiots savants'. New York, Harper \& Row
} 
A Neuropsicologia mostra que as áreas cerebrais dedicadas ao processamento da música são distintas daquelas destinadas ao processamento da linguagem, por isso que, muitas vezes, embora percam a capacidade de ouvir ou falar ainda conseguem reproduzir sons, compor músicas, reconhecer timbres (GARDNER,1994).

Algumas características de pessoas que possuem este tipo de habilidade mais desenvolvida são:

$\checkmark$ Reconhecimento de estrutura musical;

$\checkmark$ Esquemas para ouvir música (gosta de músicas mais lentas no início e depois vai, gradativamente mudando o ritmo);

$\checkmark$ Sensibilidade para sons;

$\checkmark$ Criação de melodias/ritmos;

$\checkmark$ Percepção das qualidades dos tons e sons;

$\checkmark$ Habilidade para tocar instrumentos.

Esta habilidade expressa-se de modo característico em compositores, cantores, maestros, pessoas que possuem grande habilidade na manipulação de sons, melodias e ritmos.

\subsubsection{Inteligência Lógico-Matemática}

"Inteligência Lógico Matemática - competência em desenvolver e/ou acompanhar cadeias de raciocínios, resolver problemas lógicos e lidar bem com cálculos e números, normalmente verificada em advogados, economistas, matemáticos, etc. "(RIBEIRO,1998, p.6)

A mais conhecida faculdade cognitiva é sem dúvida a LógicaMatemática. 
Ela é normalmente associada à habilidade de desenvolver raciocínios dedutivos, em construir ou acompanhar cadeias causais, em vislumbrar soluções para problemas, em lidar com números ou outros objetos matemáticos, envolvendo cálculos, transformações, etc.

Esta inteligência não requer articulação verbal, uma vez que pode resolver problemas "mentalmente", sendo necessário somente a articulação verbal na comunicação dos resultados (GARDNER et all, 1999).

Ao contrário das inteligências lingüísticas e musical, esta competência não se origina na esfera auditivo-oral, pois ela tem uma relação direta com os objetos (GARDNER,1998).

Desde o início da vida de um indivíduo esta inteligência é desenvolvida. Num primeiro momento através do contato com os objetos que estão ao alcance da mão. Depois, a contagem do número de objetos, doces, balas, e assim sucessivamente. De acordo com a idade e estímulo, estas ações começam a ser internalizadas, e passam a ser realizadas mentalmente, dispensando-se o toque para que objetos sejam contados, comparados ou subtraídos.

Uma vez que a matemática e a ciência encontram-se entre as mais admiráveis conquista da sociedade ocidental, não é surpreendente que as alegações iniciais sobre sua importância e superioridade, tenham vindo destas áreas GOLEMAN (1995). Devido a este e a outros fatores, se tornou a mais popular habilidade cognitiva, uma referência para a inteligência intelectual, sendo nos testes de medição de inteligência a mais testadas.

A Neurologia comprova as evidências de autonomia, pois alguns indivíduos são capazes de realizar façanhas matemáticas (de diferentes naturezas), mesmo na ausência de qualquer outras capacidades (GARDNER et al., 1998).

Algumas características de pessoas que possuem este tipo de inteligência são: 
$\checkmark \quad$ Reconhecimento de padrões abstratos;

$\checkmark \quad$ Raciocínio indutivo e dedutivo;

$\checkmark \quad$ Discernimento de relações e conexões;

$\checkmark \quad$ Preferências por jogos estratégicos e experimentos;

$\checkmark$ Solução de cálculos complexos.

Esta habilidade expressa-se de modo característico nos pesquisadores, matemáticos e todos os que lidam criativamente com as números e padrões.

\subsubsection{Inteligência Espacial}

“Inteligência Espacial - competência relacionada à capacidade de extrapolar situações espaciais para o concreto e vice-versa, possuindo desta forma grande percepção e relacionamento com o espaço." (RIBEIRO,1998, p.6)

A habilidade espacial está diretamente associada às atividades que necessitem uma habilidade especial na percepção e na administração do espaço (GARDNER,1998).

Essa inteligência está ligada à capacidade de perceber o mundo visual com precisão, efetuar transformações e modificações sobre as percepções iniciais e ser capaz de recriar aspectos da experiência visual, mesmo na ausência de estímulos físicos relevantes.

Essa capacidade existe em diferentes níveis, pois uma pessoa pode ter pouca capacidade de desenhar, imaginar ou transformar o mundo "ausente/virtual" e ainda assim ter uma boa percepção visual, que geralmente pode ser desenvolvida através de testes de semelhanças e diferenças de objetos, espaços e estilos, dentre outras.

"Assim como a inteligência musical consiste de capacidades rítmicas e de afinação que são às vezes dissociadas entre si e que a 
inteligência lingüística consiste em capacidades sintáticas e pragmáticas que podem também se tornar desacopladas, do mesmo modo a inteligência espacial emerge como um amálgama de capacidades. Mesmo assim o indivíduo com habilidades em diversas áreas supramencionadas tende mais a obter sucesso no domínio espacial. $O$ fato de que a prática em uma destas áreas estimula o desenvolvimento de habilidades nas áreas relacionadas é outro motivo pelo qual as habilidades espaciais podem ser razoavelmente consideradas "uma unidade". (...)"Porém, assim como a inteligência lingüística não é totalmente dependente dos canais auditivo-orais e pode desenvolver-se num indivíduo privado destes modos de comunicação, do mesmo modo, a inteligência espacial pode desenvolver até mesmo num indivíduo cego ${ }^{10}$ e que, portanto, não possui acesso direto ao mundo visual (...)" GARDNER (1994, p.135).

Pessoas com deficiência visual, geralmente possuem esta inteligência ainda mais evidenciada, uma vez que são capazes de reconhecer texturas e formato de objetos e se localizarem, fisicamente, no espaço embora não sejam capazes de visualizá-los.

A inteligência espacial acarreta capacidades, que embora possam desenvolver-se ou falhar separadamente, ocorrem juntas: a capacidade de transformar ou reconhecer um elemento em outro e a capacidade de evocar formas mentais e, então, transformá-las em outras.

Embora seja uma capacidade há muito reconhecida, ao contrário da lingüística e da lógica, poucos testes e reforços foram realizados com indivíduos adultos. Talvez, pelo fato de não saberem claramente, cientificamente, como o relacionamento entre objetos e sua reprodução mental ocorra (GARDNER,1998)

Essa é uma inteligência intensamente utilizada em nossos dias, seu desenvolvimento, chega a ser fundamental para 0 sucesso profissional, é o caso de escultores, matemático especializado em topologias, algumas áreas de engenharia, jogadores, desenhistas,

\footnotetext{
${ }^{10}$ Indivíduos cegos podem reconhecer padrões pelo tato.
} 
arquitetos, que mais do que resistência física um raciocínio espacial é necessário.

Independentemente da cultura, essa inteligência pode ser prontamente observada.

Mesmo sendo uma das inteligência que se desenvolvem a partir da percepção de objetos, a pesquisa neurológica apóia a autonomia da inteligência espacial (GARDNER et al., 1998).

Algumas características de pessoas que possuem este tipo de inteligência são:

$\checkmark$ Percepção acurada de diferentes ângulos;

$\checkmark$ Reconhecimento de relações entre objetos e espaços;

$\checkmark$ Representação gráfica;

$\checkmark$ Manipulação de imagens;

$\checkmark$ Descoberta de caminhos no espaço tridimensional;

$\checkmark$ Imaginação ativa;

$\checkmark$ Gosto por jogos do tipo quebra-cabeça.

\subsubsection{Inteligência Corporal-Cinestésica}

“Inteligência Corporal -Cinestésica - está relacionada à perfeita forma de expressão corporal, assim com a resolução de determinado problema por meio de movimentos do corpo." (RIBEIRO, 1998, p.6)

A habilidade corporal-cinestésica está presente em indivíduos que desenvolvem domínios aguçados sobre os movimentos dos seus corpos ou que conseguem manipular objetos com refinamentos.

Em muitas situações ligar a parte física à inteligência pode parecer no mínimo diferente. A dissociação entre o mental e físico esteve aliada à 
noção de que o que fazemos com nosso corpo é um tanto menos privilegiado do que as rotinas de resolução de problemas desempenhadas principalmente através do uso da linguagem, da lógica ou de algum sistema simbólico relativamente abstrato (GARDNER,1994).

Sua maior evidência está em pessoas com habilidades físicas específicas, como atletas, artistas, que seguramente não elaboram cadeias de raciocínios para realizar seus movimentos, e que na maior parte das vezes, não conseguem explicá-los verbalmente.

Os exercícios e treinamentos conseguem desenvolver tal habilidade, embora os limites alcançados diferem significativamente em diferentes indivíduos.

Dentre todas as pessoas e culturas que possuem esta habilidade desenvolvida e relevada, atletas, dançarinos e inventores são os maiores exemplos de pessoas que utilizam seus corpos, como um objeto, em direção a um objetivo.

"A inteligência lógico-matemática, cresce a partir da padronização de objetos em conjuntos numéricos; a inteligência espacial, que focaliza na capacidade do indivíduo de transformar objetos dentro do seu meio e de orientar-se em meio a um mundo de objetos no espaço; e a inteligência corporal, que, focalizando internamente, é limitada ao exercício do nosso próprio corpo, e olhando para fora, acarreta ações físicas sobre os objetos do mundo" GARDNER (1997, p.183).

Dessa forma, deve salientar, que o corpo é mais do que um simples objeto, uma máquina, ele é também um recipiente do senso do eu, de seus sentimentos e aspirações, de maneira especial, devido às suas qualidades singularmente humanas e de suas inúmeras possibilidades físicas. E, uma vez que sua existência como ser humano afeta o modo como as pessoas o tratarão, e conseqüentemente influencia seu comportamento, e vice versa, o desempenho físico pode ser aprimorado ou não a partir do desenvolvimento das inteligências pessoais, que serão descritas em um outro momento (GARDNER,1998). 
Apesar de ter sido uma das inteligências mais difíceis de serem "aceitas", pela sociedade científica, essa situação foi lentamente mudada ao ser usada como um dos argumentos para explicar funções como a do coreógrafo que utiliza seu próprio corpo para dar instruções aos dançarinos ou alpinistas, que independentemente das outras habilidades, são capazes de executar e resolver situações limites utilizando o corpo. Todas estas justificativas foram aceitas pelo fato de que a principal definição desta inteligência "(...) envolve o uso de todo o corpo ou partes do corpo para resolver problemas ou criar produtos. Operações centrais associadas e a capacidade de manipular objetos externos(...)" (GARDNER et al., 1998, p.221).

Os fundamentos biológicos dessa inteligência são complexos. Eles incluem coordenação entre sistemas neurais, musculares e perceptuais. A existência da autonomia de uma inteligência corporal-cinestésica é comprovada pela apraxia ${ }^{11}$. Embora os portadores desta síndrome não consigam realizar qualquer movimento, entendem perfeitamente as instruções e têm total consciência de qual membro deveria ser movimentado, mesmo não conseguindo movimentá-lo (GARDNER et al., 1998).

As seguintes características das pessoas que possuem esta inteligência desenvolvida podem aparecer antes de qualquer estímulo externo (treino):

$\checkmark$ Funções corporais desenvolvidas (danças, esportes, etc.);

$\checkmark$ Habilidades miméticas;

$\checkmark$ Conexão corpo-mente;

$\checkmark$ Alerta através do corpo (sentidos);

$\checkmark$ Controle dos movimentos pré-programados;

\footnotetext{
${ }^{11}$ Apraxia: síndrome neurológica tipicamente relacionada à lesão no hemisfério esquerdo.
} 
$\checkmark$ Controles dos movimentos voluntários.

\subsubsection{Inteligências Pessoais}

Há muito tempo a psicologia moderna vem dando importância diferenciada na centralidade do eu individual, uma convicção, hoje abraçada pela educação, observando-se que a capacidade para o autocrescimento e de auconhecimento é vital para a perfeita interação à sociedade em que se vive.

Dessa forma, ao conhecer-se melhor, o indivíduo estará propiciando uma melhor maneira de sobrevivência no meio onde atua e, conseqüentemente, interagir de maneira mais saudável.

Enquanto as outras inteligências foram discutidas independentes umas das outras, as inteligências pessoais - intrapessoal (envolvida principalmente no conhecimento que o indivíduo faz de seus próprios sentimentos) e interpessoal (relacionada à atuação de comportamentos, sentimento e motivação em relação aos outros) - são mais fáceis de serem interpretadas quando comparadas GARDNER (1994).

As inteligências pessoais correspondem a capacidades de processamento de informações - uma direcionada para dentro e outra para fora - que se encontram disponíveis para qualquer indivíduo.

A capacidade de conhecer-se e de conhecer os outros, (emocional e psicologicamente) é uma parte tão inalienável da condição humana quanto a capacidade de conhecer objetos ou sons, e merece ser analisada cuidadosamente, pois são algumas das muitas capacidades necessárias ao profissional solicitado pelo mercado, independementente da sua área de atuação, pois a capacidade de se adaptar está diretamente ligada à capacidade de autoconhecimento.

O funcionamento das inteligências pessoais está ligado aos lobos frontais do cérebro, portanto, se esta área sofre algum dano, a motivação e as respostas do indivíduo podem ficar prejudicadas, mesmo que a 
capacidade de desempenho num teste de QI continue inalterada (GARDNER,1995).

No dia a dia pode parecer difícil separar as inteligências, comprovar sua autonomia. Mas observar determinadas pessoas com características específicas, como autistas, ou pessoas com doenças psicopatológicas, que são capazes de observar sentimentos e motivações alheias, mas estão completamente sem consciência dos seus, serve como referência neuropsicológica de sua relação de independência (GARDNER,1995 ; GOLEMAN, 1989).

\subsubsection{Inteligência Intrapessoal}

"Inteligência Intrapessoal - capacidade de se conhecer, de entrar em contato com seu próprio "self", de se auto-avaliar. Reconhecendo seus pontos positivos e negativos, ficando desta forma mais fácil trabalhá-los.” (RIBEIRO,1998, p.7).

O desenvolvimento dessa inteligência que está associado aos aspectos internos de uma pessoa, é o acesso à sua própria vida sentimental - a gama de afeto e emoções: a capacidade de efetuar instantaneamente discriminações entre estes sentimentos e, enfim, rotulálas e envolvê-las em códigos simbólicos, baseando-se nelas como um dos meio de entender e orientar comportamentos (GARDNER, 1994).

Em sua forma mais primitiva, a inteligência intrapessoal equivale a pouco mais do que a capacidade de distinguir os sentimentos de prazer e de dor, reconhecer o que o torna feliz e como; e, o que é uma situação limite onde o prazer não existe. Com base nesta discriminação, o indivíduo tornar-se mais envolvido numa situação pessoal ou profissional, ou seja, dessa inteligência depende o processo central, que permitem às pessoas diferenciar os próprios sentimentos. 
GARDNER (1989) vê essa inteligência desenvolvendo-se a partir de uma capacidade de distinguir entre os próprios sentimentos, em seu nível mais elevado, possibilitando autocontrole e maior coerência para tomar decisões em momentos conturbados e sobre "pressão". São geralmente pessoas que conhecem suas capacidades e a melhor maneira e momento de utilizá-las. Ela permite o entendimento do motivo pelo qual reage-se ou age-se de determinada maneira em determinada situação.

Essa habilidade reforça a auto-estima, autocrescimento, e a possibilidade de resolver problemas internos, de forma que eles não atrapalhem o crescimento pessoal, profissional e sua vida em sociedade.

Essa inteligência raramente é demonstrada claramente, como é o caso da espacial pelos decoradores, ou corporal pelos atletas, salvo nos casos onde são mostrados de forma intangível, como raiva ou felicidade; ou, tangível como em poemas, pinturas ou composições, relacionados a temas pessoais.

A característica básica de uma pessoa que possui esta inteligência é a de estar bem consigo mesmo, administrando o próprio humor, os sentimentos, as emoções, os projetos, etc, tudo isso coerentemente, dentro de um contexto social e profissional.

Algumas características de pessoas que possuem este tipo de inteligência são:

$\checkmark$ Concentração total da mente;

$\checkmark$ Preocupação;

$\checkmark$ Metacoginição;

$\checkmark$ Percepção e expressão de diferentes sentimentos íntimos;

$\checkmark$ Senso de autoconhecimento;

$\checkmark$ Capacidade de abstração e raciocínio. 
Esta habilidade expressa-se de modo característico em filósofos, psiquiatras, aconselhadores espirituais (padres, pastores), educadores, dentre outros.

\subsubsection{Inteligência Interpessoal}

A inteligência interpessoal revela-se através de uma habilidade especial em relacionar-se bem com os outros, em perceber seus humores, suas motivações, em captar suas intenções, mesmo as menos evidentes, conseguir analisar questões coletivas sob diferentes pontos de vista e utilizar esta habilidade para agir com coerência e cooperativamente.

Esta habilidade possibilita o convívio com outras pessoas, em sociedade, uma vez que, embora pessoas tenham capacidade física de existir sozinhas e individualmente, o ser humano é um ser social em constante crescimento e interação (RIBEIRO,1998).

Essa inteligência emprega a capacidade central para reconhecer e fazer distinções entre os sentimentos, as crenças e as intenções (humores, temperamentos, motivações e intenções) alheias, e agir em função deles e moldá-los, para o bem ou para o mal.

Essa inteligência é vital no momento profissional atual, quando uma das maiores características solicitadas ao profissional é a capacidade de trabalhar em equipe, se automotivar, e, em muitas situações, liderar outros e estas habilidades estão diretamente ligadas à inteligência interpessoal.

Algumas características de pessoas que possuem este tipo de inteligência são:

$\checkmark$ Criação e manutenção de sinergia;

$\checkmark$ Superação e entendimento da perspectiva do outro;

$\checkmark$ Trabalho cooperativo; 
$\checkmark$ Percepção e distinção dos diferentes estados "emocionais" dos outros;

$\checkmark$ Comunicação verbal e não-verbal;

$\checkmark$ Capacidade de liderança e motivação.

Esta habilidade expressa-se de modo característico em professores, psicólogos, terapeutas, líderes religiosos, etc.

\subsubsection{Inteligência Naturalista}

Esta inteligência foi a primeira a ser adicionada às 7 iniciais e engloba a habilidade de observar, entender e organizar padrões no ambiente natural.

Como é uma inteligência que foi incluída há pouco tempo, pouca bibliografia é encontrada sobre o assunto.

Esta inteligência está ligada à habilidade de observação, entendimento e organização de padrões no ambiente natural (reconhecer a flora e fauna).

Indivíduos com essa inteligência têm a habilidade de se sentirem confortavelmente discernindo, identificando e classificando plantas, animais, aspectos geográficos, além de possuírem uma preferência por ambientes naturais (campo, bosques, fazendas, etc.).

Geralmente são pessoas que trabalham com pesquisas ligadas à fauna e flora, ou profissões ligadas às áreas (GARDNER,1999)

Algumas características de pessoas que possuem este tipo de inteligência são:

$\checkmark$ Gostar da natureza e sentir conforto ao ar livre;

$\checkmark$ Colecionar objetos do mundo natural;

$\checkmark$ Observar a natureza;

$\checkmark$ Notar as diferenças e mudanças na natureza; 
$\checkmark$ Facilidade em guardar nomes de fenômenos naturais;

$\checkmark$ Usar binóculos ou telescópio para observar a natureza;

$\checkmark$ Desenhar ou fotografar objetos da natureza;

$\checkmark$ Observar flores, espécies e diferenças existentes nas mesmas espécies e suas "respostas" aos diferentes tipos de tempo e umidade.

Esta habilidade expressa-se de modo característico em agricultores, veterinários, agrônomos, cientistas naturais, médicos que utilizam a pesquisas em plantas para desenvolver alguns medicamentos específicos, engenheiros florestais, etc.

\subsubsection{Inteligência Existencial}

Essa é responsável pela necessidade do homem fazer perguntas sobre si mesmo, sua origem e seu fim.

Está ainda em estudo, sendo considerada uma meia inteligência, por preencher apenas quatro dos oito requisitos avaliados para assegurar a existência da inteligência (2000, TRACY, 2001).

\subsection{Inteligências Múltiplas - Últimas Considerações}

As oito habilidades, possivelmente nove, relacionadas compõem um espectro onde todos os elementos e componentes interagem, equilibrando-se ou reequilibrando-se em razão de deficiências especificas (SMOLE,1998).

Pela definição da Teoria das Inteligências Múltiplas, sem estímulos específicos, seríamos todos deficientes em algum aspecto, ao mesmo tempo em que, sempre seríamos competentes em outros tantos.

A pressuposição implícita é a de que todo indivíduo teria possibilidades de um desenvolvimento global de suas habilidades, 
podendo revelar-se especialmente "inteligente" em uma ou mais áreas de interesse, de acordo com os estímulos recebidos.

Embora a teoria tenha sido desenvolvida com o objetivo de ampliar as noções psicológicas da inteligência, sua maior contribuição está na educação GARDNER et al. (1998).

No processo de ensino e aprendizagem em cursos superiores, a Teoria das Inteligências Múltiplas vem suprir a necessidade de preparar o profissional para um mercado de atuação em constante mutação.

A Teoria das Inteligências Múltiplas têm como proposta fundamental o desenvolvimento de um indivíduo completo, com habilidades diferenciadas, onde algumas delas seriam: capacidade de assimilação de diferentes conteúdos de forma natural, habilidade de resolver conflitos pessoais e profissionais em tempo hábil, capacidade de trabalhar em equipe, capacidade de transmitir escrita ou verbalmente idéias e conceitos, capacidade de analisar criticamente uma situação baseada em experiências pessoais e profissionais e propor soluções inovadoras e eficientes, dentre outras (GARDNER,1994).

Muitos profissionais das Instituições de Ensino Superior conhecem a necessidade do mercado atual, são altamente capazes de fazer preleções sobre o mercado profissional futuro e sabem até onde poderiam ajudar no desenvolvimento pessoal e profissional dos estudantes, mas o como isso poderia ser operacionalizado ainda é uma incógnita para alguns.

Esta consciência reforça a teoria de que mais do que uma boa formação técnica é necessária um aprimoramento pessoal e profissional de uma forma diferenciada.

Paulo Ferraz, presidente do Bozano Simonsen, em entrevista na revista EXAME (1998), diz que as característica procuradas na hora da contratação vão além daquelas técnicas, adquiridas hoje nas instituições de ensino, como flexibilidade, visão do todo, capacidade de trabalhar em equipe. Existem outras características essenciais e a sociedade tem-se 
conscientizado de que diferentes pessoas possuem diferentes tipos de habilidades, de que há a possibilidade de desenvolvimento das menos expressivas, e de que estas habilidades podem ser aprimoradas dentro das próprias instituições de ensino, facilitando o trabalho dos processos de treinamentos e tornando os estágios sejam mais recompensadores e expressivos.

Durante a fase universitária, em cursos da área de engenharia, a maior ênfase é dada ao estímulo da capacidade de raciocínio, a qual GARDNER (1994) chama de inteligência Lógica/Matemática. Os outros tipos de inteligências interpessoal e intrapessoal são pouco estimulados, sem falar da pouca ênfase que é dada ao estímulo da habilidade lingüística. Mas ao chegar ao mercado de trabalho, o profissional é constantemente solicitado a utilizar-se destas habilidades, começando pela necessidade de elaborar, por escrito, relatórios técnicos, memorandos, propostas, de falar para um grupo de pessoas sobre assuntos relacionadas à sua área de atuação, de liderar uma reunião, de trabalhar em equipe, dentre outras. Percebe-se, então o quanto o profissional está despreparado.

Não é estabelecido que o ensino tradicional de cursos da área de exatas, não possa pesquisar temas relacionados ao assunto a ser abordado em sala de aula, ou a dissertação crítica de uma resposta numérica de um determinado exercício, nem mesmo seminários a respeito de um assunto que está sendo estudado, geralmente estas técnicas são utilizadas em cursos de Pós-graduação.

Embora haja cada vez mais pessoas ingressando nos cursos de pós-graduação, a sobrevivência no mercado de trabalho é a necessidade primária de uma pessoa que opta por um curso de graduação e se o objetivo é formar melhores profissionais que os de ontem, por meio do uso de todas as possibilidades para atingir este objetivo.

A proposta das universidades é colocar pessoas no mercado de trabalho com a melhor capacitação possível e nada mais justificável que 
isso ocorra durante o processo de formação, quando os alunos estão abertos a todo tipo de estímulos, buscando uma formação sólida e eficaz, preparando-se, inclusive, para uma perfeita adaptação e aproveitamento dos cursos de pós-graduação.

Considerando o momento atual, o estímulo das Inteligências Múltiplas dentro da sala de aula surge como uma proposta viável para alterar de forma definitiva os aspectos operacionais do processo de Ensino/Aprendizagem.

Tanto os recursos técnicos disponíveis quanto os recursos humanos, como professores mais capacitados, devem ser ajustados com o intuito de atender à demanda por uma educação continuada, buscando sempre, qualificar o estudante, tendo em vista os desafios que estão Ihes sendo impostos no cotidiano do trabalho, na preparação para uma educação continuada e na formação de uma cultura universitária empreendedora. 


\section{A UTILIZAÇÃO DA TEORIA DAS INTELIGÊNCIAS MÚLTIPLAS AGREGADA ÀS ESTRATÉGIAS DE ENSINO: AULA EXPOSITIVA, SEMINÁRIO E PROJETO}

No momento da escolha de um dos métodos de ensino existentes, 0 educador deve ter em mente que o "ensinar" caracteriza-se pela combinação de atividades e deveres entre todos os envolvidos no processo de ensino e aprendizagem.

Nesse processo, sob a direção do educador, os estudantes vão atingindo gradativamente o desenvolvimento de suas capacidades mentais. O sucesso do desenvolvimento está diretamente ligado à capacidade do educador de sistematizar, tanto no planejamento quanto no desenvolvimento das aulas, os objetivos, conteúdos e as estratégias com a finalidade de facilitar o processo de ensino (LIBÂNEO,1994).

A relação, segundo LIBÂNEO (1994) e MASETTO (1995), que existe em objetivo-conteúdo-estratégia tem como característica a mútua interdependência e constitui a linha fundamental de compreensão do processo didático. 
Os objetivos explicitaram os propósitos pedagógicos intencionais e planejados de instrução e educação dos estudantes, para que consigam participação na vida social e profissional.

Os conteúdos constituem a base informativa concreta para determinar os métodos e alcançar os objetivos.

As estratégias formam a totalidade dos passos, formas didáticas e meios organizativos do ensino que viabilizam a assimilação dos conteúdos.

Dentre as estratégias mais utilizadas no ensino de engenharia podem citar: aula expositiva, seminários e desenvolvimento de projetos. Essas estratégias, quando bem trabalhadas, capacitam o desenvolvimento de habilidades que hoje são necessárias para a inserção do profissional no mercado (BERBEL, 1994).

Ao se optar por uma das estratégias acima mencionadas, alguns requisitos devem ser considerados como forma de se obter o máximo no desenvolvimento pessoal e técnico exigido pelo mercado:

a)PREPARO ESPECIALIZADO DA MATÉRIA - qualquer conteúdo a ser trabalhado requer do responsável um conhecimento bem mais profundo do que é exigido pelo programa. Isso é importante para que ele consiga ressaltar aspectos fundamentais e esclarecer dúvidas práticas e teóricas. Uma experiência prática na área é fundamental para se fazer à ligação entre o objetivo da disciplina, o conteúdo a ser trabalhado, as características pessoais e técnicas que poderão ser desenvolvidas e as exigências mercadológicas (BEBEL, 1994).

b)CULTURA GERAL E UM CONHECIMENTO SOBRE AS NECESSIDADES REAIS MERCADOLÓGICAS - todas as áreas de conhecimento são inter-relacionadas; portanto, um conhecimento globalizado dos assuntos é fundamental em todas as fases do processo de ensino e aprendizagem, desde a formulação do conteúdo a ser trabalhado, a escolha da estratégia correta até o desenvolvimento da aula presencial, que culmina na utilização das estratégias escolhidas. 
c) CONHECIMENTO E hABILIDADES PEDAGÓgICAS - independentemente se é através da leitura, de cursos ou mesmo da prática diária, o educador deve dispor de conhecimentos e habilidades que facilitem o processo de ensino. Esse conhecimento e esta facilitação podem vir da prática escolhida para trabalhar o conteúdo da disciplina e de como as estratégias utilizadas se adaptam ao assunto a ser trabalhado.

A utilização da Teoria das Inteligências Múltiplas, como direcionamento para o desenvolvimento de habilidades adicionais, possibilita ao educador ajudar a transformar dados em informações e estas em conhecimento. Ao mesmo tempo desenvolve nos indivíduos uma maior conscientização do seu papel como pessoa e profissional.

A estratégia utilizada dentro da sala de aula funciona como uma técnica insuperável para transmitir a informação necessária do assunto a ser trabalhado. Mas ajudar a transformá-lo em conhecimento e em mudanças de atitudes requer uma percepção maior por parte do responsável pelo processo de ensino e aprendizagem. Essa percepção pode ser desenvolvida num grau maior se houver a possibilidade de utilizar um referencial como forma de monitoramento de atividades didáticas (GARDNER, 1995).

A Teoria das Inteligências Múltiplas, por ser uma teoria e não um método estruturado, ajuda neste direcionamento, cujo objetivo é desenvolver um profissional o mais próximo possível do solicitado pelo mercado.

A Teoria das Inteligências Múltiplas leva em consideração características pessoais individuais e aponta, sem classificar, para formas de desenvolver determinadas características pessoais. Por isso, tê-la como uma variável ativa durante a atividade da utilização das estratégias (seminário, aula expositiva, projeto) é uma forma de garantir o sucesso do desenvolvimento de características pessoais - capacidade de trabalhar em equipe, capacidade de escrever, ler e falar em público, capacidade de trabalhar de forma individual e a capacidade de utilizar as habilidades lógico- 
matemáticas desenvolvidas dentro dos cursos de exatas - de forma integrada às características técnicas.

Portanto, agregar a Teoria das Inteligências Múltiplas às estratégias de ensino em cursos de $3^{\circ}$ grau tem como objetivo revitalizar o ensino e facilitar a aprendizagem de forma a suprir as necessidades de mercado por um profissional que saiba inter-relacionar as habilidades técnicas e pessoais.

\subsection{Aula Expositiva}

Segundo GIL (1994), a aula expositiva consiste numa preleção verbal e escrita, utilizada pelos professores com o objetivo de transmitir informações sobre um determinado conteúdo específico. É uma estratégia antiga e, no Brasil, constitui seguramente a mais empregada no ensino de graduação. Em muitos cursos universitários é utilizado quase que de forma exclusiva e são em grande número as pessoas que identificam ensino com exposição de conteúdos.

A aula expositiva, no sentido clássico, fundamenta-se na idéia de que é possível ensinar por meio da explicação oral, ou seja, condensar o conhecimento e expô-lo, verbalmente ou por meio da escrita, de forma lógica e clara. Assim, nesta técnica, a comunicação é importante para que ocorra a transmissão da informação e a recepção dela de forma correta.

$\mathrm{Na}$ aula expositiva, como o próprio nome diz, o foco está na exposição, feita por pessoas que tenham um conhecimento satisfatório sobre o assunto, e por isso, pode ocorrer o negligenciamento da importância do interesse e da atenção do aluno. Uma palavra desconhecida mencionada, um ritmo de fala maior do que o habitual, muitas idéias expostas ao mesmo tempo pode fazer com que a informação a ser transmitida não seja retida.

Como a grande responsável pelo sucesso dessa técnica é a comunicação, podem-se utilizar os mesmos princípios básicos para garantir sua eficiência. O educador será o emissor, que tem como objetivo fazer com 
haja a assimilação do conteúdo utilizando-se dos recursos ${ }^{1}$ disponíveis (canais) para que a mensagem seja recebida e compreendida pelo receptor que são os estudantes (GIL, 1994).

\subsubsection{Aplicação dos princípios da comunicação na aula expositiva}

Segundo GIL (1994) e BERBEL (1994) a comunicação é um processo de inter-relação entre pessoas e sua eficácia tem a ver não apenas com habilidades de abstração e de transmissão de informação, mas também com o canal em que está veiculada e sobretudo da disposição do receptor, que poderá realimentar todo processo com manifestações sobre os efeitos produzidos nele pela mensagem emitida, ou seja, feedback, segundo esquema da FIGURA 7.1.

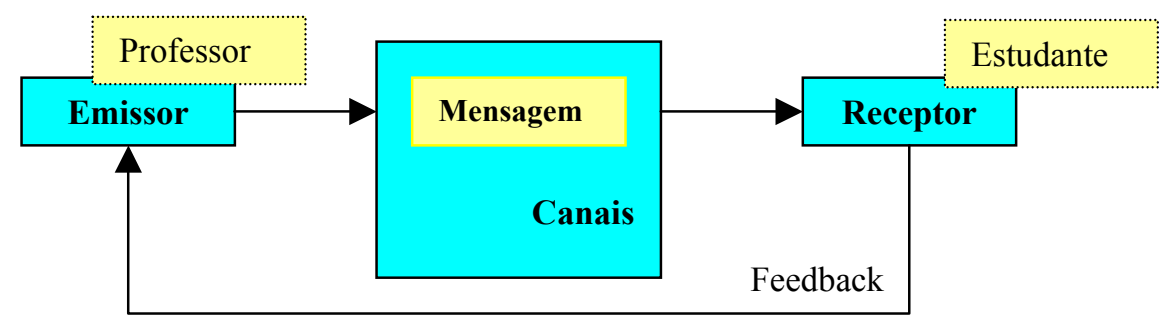

FIGURA 7.1: Esquema básico do processo de comunicão relacionado ao processo de ensino e aprendizagem em uma aula expositva, objetivando a assimilação da mensagem de forma satisfatória.

A aula expositiva requer alguns cuidados para que seja bem preparada e utilizada com eficiencia, segundo GIL (1994), BERBEL (1994), MOREIRA (1997) e GODOY (1988), esses cuidados podem ser definidos em:

\footnotetext{
${ }^{1}$ Por recursos utilizados podemos citar cartazes, quadro negro, computadores, dentre outros.
} 
a) DEFINIR COM CLAREZA SEUS OBJETIVOS - é fundamental, para a clareza da exposição, que o educador conheça o assunto a ser abordado. Muitos educadores esquecem de precisar exatamente o que pretendem alcançar, tanto em relação à capacidade técnica como de habilidades, durante a atividade didática. A precisão e a clareza dos objetivos a serem alcançados facilita o e ritmo a ser adotado durante a atividade efetiva de sala de aula e estimula aos envolvidos no processo de aprendizagem, para novas perspectivas de compreensão e reflexão sobre o tema;

b) CONSIDERAR O TIPO DE PÚBLICO ATUAL - conhecer seu "público" e que tipo de conhecimentos prévios eles possuem, facilita a escolha do vocabulário correto e também dos exemplos a serem utilizados, possibilitando uma maior compreensão, por parte dos envolvidos, do processo de aprendizagem;

c) ORganizAR AS IDÉIAS - exige um domínio maior do conteúdo a ser trabalhado, assim como a habilidade de agregar ao conteúdo técnico as capacidades específicas pessoais a serem desenvolvidas. Ao organizar as idéias, o processo de desenvolvimento do profissional de forma globalizada (pessoal e técnica), torna-se mais propenso ao sucesso;

d) Planejar a estrutura dA AULA - este tópico complementa o anterior, sendo que nesse momento a definição dos objetivos a serem alcançados e a seqüência a ser seguida já deverá ter sido estabelecida, cabendo definir os pontos mais importantes a serem destacados e quando. Dentro desse planejamento efetivo ainda há a necessidade de ficar atento à:

i. Duração total da aula - cansaço: uma vez que a exposição oral, realizada apenas pelo professor, tende a ser mais cansativa que algumas outras estratégias, deve-se ficar atento às linguagens abstratas e corporais dos estudantes para que a sensação de cansaço e conseqüentemente a desatenção sejam evitadas;

ii. Prever começo, meio e fim de cada aula: a introdução de uma aula expositiva, assim como seu desenvolvimento e sua conclusão devem ser 
minuciosamente identificados pelo educador para que haja um maior domínio e interação dos participantes do processo de ensino e aprendizagem;

e) USO DE APONTAMENTOS - utilizados com moderação, não se limitando a lê-los, é um recurso importante para que sejam cumpridos vários dos tópicos aqui relacionados. Também é o caso de utilização de recursos, principalmente os audiovisuais, que podem facilitar e auxiliar nas atividades de ensino. Todos os recursos devem estar cuidadosamente relacionados ao objetivo da aula, para serem utilizados de forma eficiente;

f) COMUNICAÇÃO ORAL - ou "cuidar" do tom de voz e o ritmo a ser empregado durante a atividade - o tom de voz e o ritmo da explanação do conteúdo são importantes para chamar a atenção para informações relevantes. Isso possibilita aos alunos uma participação mais efetiva e um aprimoramento maior de habilidades pessoais. A modulação da voz, a clareza na dicção e a introdução de pausas, durante a explicação, feita com moderação, é um bom recurso para captar a atenção das pessoas, além de possibilitar ao discente a organização da informação recebida. Isso favorece ao exame das idéias tratadas e a oportunidade de elaboração de perguntas e determinação de correlação com os diversos temas, conteúdos, disciplinas já conhecidos.

Além desses tópicos, deverá haver um cuidado maior na postura do educador em sala de aula e na forma como se expressa verbalmente e nas suas atitudes, pois muitos estudantes poderão utilizá-las como modelo para a vida profissional futura.

$\mathrm{Na}$ atividade de aula expositiva, geralmente, a apresentação verbal e, eventualmente, a escrita está incluída e, optar pela melhor informação, a ser trabalhada e disponibilizada, recai sobre o tipo de audiência ou público, ou seja, pelo perfil geral dos estudantes.

Nesse contexto, fica claro o cuidado que se deve ter com a mensagem a ser trabalhada, assim como o canal - livro, artigos, apostilas, etc - se é condizente ou não com as habilidades atuais das pessoas 
envolvidas no processo de assimilação do conteúdo e no desenvolvimento de capacidades e atitudes.

O cuidado com o material é apenas um dentre os vários cuidados que se deve ter. Gil (1994) chega a ser mais específico ao pontuar alguns cuidados que devem existir:

$\checkmark$ Cuidar para que a mensagem se ajuste às características e necessidades da audiência em questão - há sempre a necessidade de conhecer relativamente bem os envolvidos, para determinar o momento certo para a interferência do educador, seja para trabalhar conceitos anteriores ou inserir novos a serem assimilados;

$\checkmark$ Elaborar a mensagem de forma clara, precisa e concisa - quanto mais técnico for o texto, maior dificuldade haverá da assimilação do conteúdo. Como na aula expositiva, onde o professor transmite verbalmente o conteúdo, estar atento ao modo como é falado, comentado e abordado em livros e artigos, determinados assuntos, pode determinar o sucesso ou não da utilização dessa técnica;

$\checkmark$ Planejar a seqüência dos tópicos - planejar é fundamental em todos os momentos. Para se atingir o objetivo é recomendável que a utilização da seqüência "todo-parte-todo" seja utilizada, ou seja, a partir de uma contextualização global sobre o assunto a ser trabalhado e seus conceitos, para posteriores conclusões. Isto é, discussões finais sobre o conteúdo e conclusões trazem uma maior participação, minimizando a sensação de passividade que ocorre, muitas vezes, nesta estratégia;

$\checkmark$ Considerar não só a seqüência lógica dos fatos, mas a psicológica - nesse momento, a motivação se torna fundamental. A motivação dos alunos para que "prestem atenção" em uma aula expositiva pode ocorrer através do recurso de contextualização inicial do assunto, levando-os à percepção da importância do que será abordado e, com isso, manter a atenção por um tempo maior;

$\checkmark$ Demonstrar um certo colorido emocional à situação e, oportunamente, incluir histórias, fatos pitorescos e situações problemáticas - 
sempre com o intuito de manter os envolvidos em atitudes reflexivas. Muitas vezes esses recursos são utilizados sem a exata dimensão de que poderia estar desenvolvendo, de uma maneira sutil, a atitude reflexiva do educando. Ao inserir uma anedota ocorre um desligamento, consciente, do assunto que estava sendo discutido, para que no retorno ao contexto, os estudantes sejam capazes de fazer analogias e deduções que antes, por estarem envolvidos tão conscientemente na técnica expositiva, não era possível. Portanto, entremear a exposição com discussões, exercícios e realização de experiências simples facilita a assimilação do conteúdo técnico, enquanto desenvolvem-se habilidades de concentração, de raciocínio lógico, de trabalho em equipe e individual.

Todos estes tópicos, ao serem observados, fazem com que a aula expositiva e sua relação de passividade pelos receptores seja trabalhado, assim como o processo de feedback, provendo tanto informações sobre como está sendo desenvolvida a técnica, quanto o que está sendo assimilado pelos educandos.

Manter-se atento também às reações cotidianas dos educandos serve de direcionamento para a dinâmica da estratégia, minimizando a ocorrência do educador se entusiasmar com sua própria atuação e não perceber a necessidade de maior clareza e, em alguns momentos, da mudança de abordagem e estratégia.

\subsubsection{Vantagens da utilização da aula expositiva}

Essa estratégia pode ser trabalhada por qualquer profissional que domine o conteúdo a ser abordado, mesmo que não disponha de maiores conhecimentos pedagógicos.

Essa estratégia, como todas as outras, só se torna eficiente quando é bem planejada, e executada de acordo com certos princípios. E, apesar dela ser tão largamente utilizada e conhecida, pode-se considerá-la tão ou 
mais difícil quanto qualquer outra estratégia utilizada no ensino de graduação.

Segundo GIL (1994), GODOY (1988) e MOREIRA (1997), a aula expositiva, do ponto de vista pedagógico, é adequada para:

$\checkmark$ Transmitir conhecimentos;

$\checkmark$ Apresentar um assunto de forma organizada;

$\checkmark$ Introduzir determinados assuntos novos;

$\checkmark$ Despertar a atenção em relação a um determinado assunto;

$\checkmark$ Transmitir experiências e observações pessoais não disponíveis sob outras formas de comunicação;

$\checkmark$ Sintetizar ou concluir uma unidade de ensino de um conteúdo ou um curso;

A forma clássica de exposição é geralmente utilizada para transmitir informações; no entanto, observando a própria dinâmica das salas de aula, pode ser verificado que ela atende a uma variedade de propósitos, tendo em vista a aquisição de conhecimentos que sejam realmente significativos e desperte o interesse do aprendiz.

Segundo MOREIRA (1997), BERBER (1994) e GIL (1994), no ensino superior, a média de estudantes dentro da sala de aula, muitas vezes pode superar as expectativas, e a utilização da estratégia de aula expositiva tornase mais econômica e mais conveniente na aplicação. Os argumentos favoráveis à atividade em si em relação à aula expositiva são:

$\checkmark$ Poupa tempo dos professores na preparação;.

$\checkmark$ Possível transmitir, num tempo menor, grande quantidades de informações;

$\checkmark$ Minimiza o desconforto dos estudantes em disciplinas que seriam pouco assimiladas apenas pela leitura;

$\checkmark$ Pode apresentar uma primeira visão de um novo tema; 
$\checkmark$ É fundamental quando existem muitos livros que tratem do assunto ou o oposto;

$\checkmark$ Necessárias quando os alunos não estão, intelectualmente, habilitados e tendem aprender mais ouvindo do que lendo;

$\checkmark$ Ideal quando se necessita de um ambiente estruturado para 0 aprendizado e apresentam dificuldades em lidar com texto escrito e usar com eficiência material bibliográfico indicado pelo professor;

$\checkmark$ Requer um mínimo de preparação e conduta dos envolvidos - uma vez que já participaram da técnica inúmeras vezes;

$\checkmark$ Ser a estratégia de custo mais baixo de ser utilizada;

$\checkmark$ Requer um mínimo de conhecimento prévio para sua utilização;

$\checkmark$ Ser flexível o suficiente para ser utilizada em conjunto com várias outras existentes;

$\checkmark$ Ser um meio rápido, onde o conteúdo a ser apreendido é apresentado em sua forma final;

$\checkmark$ Requerer do estudante apenas o entendimento da mensagem, procurando, simultaneamente, desenvolver seu raciocínio crítico.

No TABELA 7.1 tem-se um resumo sobre os principais cuidados que se deve ter ao preparar e realizar uma aula expositiva. 
TABELA 7.1 Resumo das principais características da Aula Expositiva.

\begin{tabular}{|c|c|c|c|c|}
\hline $\begin{array}{c}\text { CONHECIMENTO DO MERCADO } \\
\text { PROFISSIONAL }\end{array}$ & $\begin{array}{l}\text { CUIDADOS NA } \\
\text { PREPARAÇÃO DA } \\
\text { ATIVIDADE } \\
\end{array}$ & $\begin{array}{c}\text { CUIDADO NA PREPARAÇÃO DO } \\
\text { MATERIAL }\end{array}$ & CuIdAdos Pedagógicos & $\begin{array}{c}\text { CUIDADOS DURANTE A ATIVIDADE } \\
\text { EXPOSITIVA }\end{array}$ \\
\hline $\begin{array}{l}\text { Preparar o conteúdo dentro } \\
\text { do contexto profissional }\end{array}$ & $\begin{array}{l}\text { Definir com clareza os } \\
\text { objetivos }\end{array}$ & $\begin{array}{l}\text { Cuidar para que a mensagem se } \\
\text { ajuste às características e } \\
\text { necessidades da audiência em } \\
\text { questão }\end{array}$ & $\begin{array}{l}\text { Transmitir informações } \\
\text { concisas e } \\
\text { coerentemente. }\end{array}$ & $\begin{array}{l}\text { Minimizar o desconforto da } \\
\text { passividade do método } \\
\text { adicionando situações/casos } \\
\text { reais. }\end{array}$ \\
\hline $\begin{array}{l}\text { Ter cultura geral e um } \\
\text { conhecimento sobre as } \\
\text { necessidades de um perfil } \\
\text { específico }\end{array}$ & $\begin{array}{l}\text { Considerar o tipo de } \\
\text { público atual }\end{array}$ & $\begin{array}{l}\text { Elaborar a mensagem de forma } \\
\text { clara, precisa e concisa }\end{array}$ & $\begin{array}{l}\text { Apresentar um assunto de } \\
\text { forma organizada }\end{array}$ & $\begin{array}{l}\text { Apresentar uma primeira visão } \\
\text { de um novo tema }\end{array}$ \\
\hline & Organizar as idéias & Planejar a seqüência dos tópicos. & $\begin{array}{l}\text { Introduzir assuntos novos } \\
\text { constantemente ou novas } \\
\text { visões sobre mesmo } \\
\text { assunto }\end{array}$ & $\begin{array}{l}\text { É fundamental quando existem } \\
\text { muitos livros que tratem do } \\
\text { assunto ou o oposto }\end{array}$ \\
\hline & $\begin{array}{l}\text { Planejar a estrutura da } \\
\text { aula: } \\
\text { Duração total da aula } \\
\text { Prever começo, meio } \\
\text { e fim de cada aula } \\
\end{array}$ & $\begin{array}{l}\text { Demonstrar um certo colorido } \\
\text { emocional à situação e inovar } \\
\text { sempre utilizando recursos como: } \\
\text { anedotas, fatos pitorescos e } \\
\text { situações problemáticas }\end{array}$ & $\begin{array}{l}\text { Despertar a atenção em } \\
\text { relação a um determinado } \\
\text { assunto }\end{array}$ & $\begin{array}{l}\text { Necessária quando os alunos } \\
\text { não estão,intelectualmente, } \\
\text { habilitados e tendem aprender } \\
\text { mais ouvindo do que lendo. }\end{array}$ \\
\hline & Uso de apontamentos & Comunicação oral & $\begin{array}{l}\text { Transmitir experiências e } \\
\text { observações pessoais não } \\
\text { disponíveis sob outras } \\
\text { formas de comunicação }\end{array}$ & $\begin{array}{l}\text { Requer um mínimo de } \\
\text { preparação e conduta dos } \\
\text { envolvidos - uma vez que já } \\
\text { participaram da técnica } \\
\text { inúmeras vezes; }\end{array}$ \\
\hline & \multirow{2}{*}{$\begin{array}{l}\text { conhecimento prévio } \\
\text { para sua utilização; }\end{array}$} & \multirow{2}{*}{$\begin{array}{l}\text { Ser flexível o suficiente para ser } \\
\text { utilizada em conjunto com várias } \\
\text { outras existentes }\end{array}$} & \multirow{2}{*}{$\begin{array}{l}\text { Sintetizar ou concluir uma } \\
\text { unidade de ensino de um } \\
\text { conteúdo ou um curso } \\
\text { sempre. }\end{array}$} & $\begin{array}{l}\text { Ser a estratégia de baixo custo } \\
\text { de utilização; }\end{array}$ \\
\hline & & & & $\begin{array}{l}\text { Transmitir, num tempo menor, } \\
\text { grande quantidades de } \\
\text { informações }\end{array}$ \\
\hline
\end{tabular}




\subsubsection{A aula expositiva e sua relação com a Teoria das Inteligências Múltiplas}

Minimizar o descompasso existente no ensino superior, entre a preparação técnica - que qualifica o indivíduo para exercer a profissão escolhida, e a pessoal - que o qualifica como profissional competente, leva a iniciativas pedagógicas para elevar a excelência do ensino.

A utilização da Teoria das Inteligências Múltiplas como direcionamento, dentro do contexto da estratégia aula expositiva, visa a diminuir esse descompasso, enquanto serve de ferramenta no desenvolvimento consciente de características e posturas exigidas atualmente.

Dentre as várias características necessárias para o bom desempenho profissional nos dias de hoje, podem-se destacar:

$\checkmark$ Habilidade técnica específica da área de atuação da profissão escolhida;

$\checkmark$ Capacidade de trabalhar em equipe (aprender a trabalhar em equipe);

$\checkmark$ Facilidade e capacidade de "aprender a aprender", desenvolvendo a autonomia do aprendizado;

$\checkmark$ Desenvolvimento de trabalhos individuais sem, contudo, perder a dimensão do todo;

$\checkmark$ Capacidade de expressão oral e escrita.

Essas características poderão ser largamente estimuladas, durante as aulas expositivas, se forem direcionadas pela Teoria das Inteligências Múltiplas, mesmo sendo, essa estratégica, totalmente centralizada e direcionada pelo responsável pela transmissão do conteúdo técnico.

Ao fazer um paralelo entre a Teoria das Inteligências Múltiplas e as características pessoais/técnicas necessárias ao profissional de engenharia, pode-se observar que elas estão diretamente interligadas, por definição. Ou 
seja, ao estimular determinadas inteligências, o que se consegue é um desenvolvimento melhor da técnica e das características pessoais/profissionais da área (TABELA 7.2).

TABELA 7.2: Aula expositiva, capacidades e inteligências estimuladas

\begin{tabular}{|c|c|c|}
\hline & Capacidades & Inteligências \\
\hline 1 & $\begin{array}{l}\text { Habilidade técnica específica } \\
\text { da área de atuação da } \\
\text { profissão escolhida }\end{array}$ & $\begin{array}{l}\text { Inteligência Lógica } \\
\text { Inteligência pessoal (inter e intrapessoal) } \\
\text { Inteligência Lingüística }\end{array}$ \\
\hline 2 & $\begin{array}{l}\text { Capacidade de trabalhar em } \\
\text { equipe. (aprender a trabalhar } \\
\text { em equipe); }\end{array}$ & $\begin{array}{l}\text { Inteligência pessoal (inter e intrapessoal) } \\
\text { Inteligência lingüística }\end{array}$ \\
\hline 3 & $\begin{array}{l}\text { Facilidade e capacidade de } \\
\text { "aprender a aprender"; }\end{array}$ & $\begin{array}{l}\text { Inteligência pessoal (inter e intrapessoal) } \\
\text { Inteligência lingüística } \\
\text { Inteligência lógica }\end{array}$ \\
\hline & $\begin{array}{l}\text { Desenvolvimento de trabalhos } \\
\text { individuais sem, contudo, } \\
\text { perder a dimensão do todo; }\end{array}$ & $\begin{array}{l}\text { Inteligência Intrapessoal } \\
\text { Inteligência lógica }\end{array}$ \\
\hline 5 & $\begin{array}{l}\text { Capacidade de expressão oral } \\
\text { e escrita; }\end{array}$ & $\begin{array}{l}\text { Inteligência pessoal (inter e intrapessoal) } \\
\text { Inteligência lógica } \\
\text { Inteligência lingüística }\end{array}$ \\
\hline
\end{tabular}

A aula expositiva pode ser dividida em vários momentos interligados, que se repetem durante toda a atividade, dentre eles: a expressão oral, por parte do facilitador, do conteúdo, a expressão escrita de todo conteúdo ou de conceitos importantes, a solicitação de respostas (feedback) dos estudantes. 
Na expressão oral, por um certo período, a sensação de passividade pode vir a existir e causar uma certa desconcentração, por parte de alguns estudantes. Nesse instante, podem ocorrer conversas paralelas. Aqui tem início o desenvolvimento do senso de responsabilidade do grupo que está diretamente ligado à característica 2 - capacidade de trabalhar em equipe da TABELA 7.2.

Durante a atividade, o educador deverá fazer uma abordagem sobre o espírito de cooperação em equipe, de acordo com sua habilidade, de modo que os próprios participantes do processo tomem consciência de que já pertencem a um grupo e a conduta de uns influencia diretamente o desempenho de todos. Essa percepção induzida é o começo do desenvolvimento das inteligências pessoais.

A partir da percepção individual (inteligência intrapessoal - ao fazer com que as condutas alheias não tragam grandes transtornos ao seu processo de aprendizagem) e do grupo (inteligência interpessoal - ajudando o outro a tomar consciência da sua responsabilidade no desenvolvimento do grupo), é desenvolvido o espírito de cooperação e as conversas paralelas tendem a ser minimizadas devido ao fato de entenderem que há determinados "conhecimentos" que não serão adquiridos em livros ou em outros momentos.

A responsabilidade de integração do grupo e o desenvolvimento do senso de responsabilidade individual e grupal não é do educador. A ele cabe apenas expor que pessoas diferentes, trabalhando dentro do mesmo ambiente, com condutas e interesses individuais sempre existirá. Ou seja, estimula a consciência de que a sala de aula deve ser encarada com um laboratório para atividades e condutas futuras e que todos pertencem a um mesmo ambiente com alguns objetivos comuns.

Enquanto ocorre a explicação oral e escrita, a inteligência lógica é estimulada, pois, conforme o assunto vai sendo abordado novas associações cognitivas vão sendo desenvolvidas e interiorizadas. 
Muitas vezes, questões que trabalham essas associações podem ser formuladas e os estudantes terão que recorrer a conceitos pré-estabelecidos para respondê-las.

Durante todo processo da aula expositiva, a inteligência lingüística é estimulada. Por isso, é crucial que o educador tome todo cuidado com sua postura escrita e falada porque dela dependerá todo o desenvolvimento por parte dos estudantes. A utilização correta do vocabulário da área, assim como uma expressão clara e objetiva de todos os assuntos servirá de exemplo e de subsídios para uma posterior avaliação do desenvolvimento da postura profissional.

A expressão oral e escrito é fundamental para o bom desempenho profissional de qualquer área, e especificamente dentro do ensino de engenharia deverá ser estimulada de forma diferenciada uma vez que a maior ênfase está no desenvolvimento lógico e técnico do indivíduo, dandose muita pouca ênfase à postura escrita e falada do estudante, como se não as fosse utilizar nunca na vida profissional. Nesse contexto, o exemplo torna-se fundamental, bem como o estímulo diferenciado em direção à inteligência lingüística. A discussão de textos relacionados à área e ao conteúdo a serem trabalhados pode servir como aliada nesse momento, fazendo que, além da capacidade de leitura e abstração de um texto escrito relacionado a um assunto técnico, seja desenvolvida a capacidade crítica individual de utilização prática e efetiva do conteúdo.

Esses textos podem vir em forma de artigos científicos, projetos apresentados, capítulos de dissertação/teses ou até mesmo manuais técnicos específicos, lembrando da atenção ao modo como foram escritos. $O$ professor não deve apenas apresentar o texto à classe, mas deixar claro, num primeiro momento, a quais características, além do conteúdo, os estudantes deverão estar atentos.

Devido à imaturidade, nas atividades iniciais, os estudantes devem ser constantemente monitorados para que ocorra o efetivo desenvolvimento. Deve-se deixar claro as estruturas utilizadas e durante a atividade didática 
solicitar que reproduzam textos relacionados aos assuntos trabalhados. Num primeiro momento mostrar como outras pessoas executaram a tarefa, num segundo momento solicitar que a atividade seja realizada por eles, seguindo determinados padrões, mas com a possibilidade de criação e desenvolvimento pessoal de estruturas pessoais.

Esse aprendizado é necessário, uma vez que será fundamental adquirir esse tipo de habilidade ao desenvolver qualquer tipo de atividade da área de atuação do engenheiro. Leitura, desenvolvimento e exposição de projetos serão constantemente solicitados, assim como as capacidades de gestão de pessoas, materiais e do tempo destinados a determinadas atividades. Saber falar, escrever corretamente e com o intuito de expor idéias concisas e claras é importante e, só pode ser desenvolve a partir de leituras e práticas relacionadas a estas atividades e de exemplos.

Seguindo a estrutura da TABELA 7.2, a TABELA 7.3 exemplifica algumas atividades que poderão ser desenvolvidas $\mathrm{e}$ as respectivas inteligências estimuladas:

Como pode ser observado, não se trata de acabar com a estrutura de sala de aula ou com a aula expositiva, mas simplesmente revitalizá-la, contando inclusive com o suporte dos recursos (giz, quadro negro, equipamentos tecnológicos, etc) e tendo como colaboradora para o sucesso pedagógico da disciplina a Teoria das Inteligências Múltiplas. 
TABELA 7.3: Aula expositiva, capacidades, inteligências estimuladas e momentos

\begin{tabular}{|c|c|c|c|}
\hline & Características & Inteligências & Momento \\
\hline 1 & $\begin{array}{l}\text { Habilidade técnica } \\
\text { específica da área } \\
\text { de atuação da } \\
\text { profissão escolhida }\end{array}$ & $\begin{array}{l}\text { Inteligência Lógica } \\
\text { Inteligência pessoal } \\
\text { (inter e intrapessoal) } \\
\text { Inteligência Lingüística }\end{array}$ & Todos os momentos \\
\hline 2 & $\begin{array}{l}\text { Capacidade de } \\
\text { trabalhar em } \\
\text { equipe. (aprender } \\
\text { a trabalhar em } \\
\text { equipe); }\end{array}$ & $\begin{array}{l}\text { Inteligência pessoal } \\
\text { (inter e intrapessoal) } \\
\text { Inteligência lingüística }\end{array}$ & $\begin{array}{l}\text { Expressão Oral (1 ) } \\
\text { Expressão Escrita* }{ }^{*}(1) \\
\text { Pesquisas em assuntos } \\
\text { relacionados (2) }\end{array}$ \\
\hline 3 & $\begin{array}{l}\text { Facilidade e } \\
\text { capacidade de } \\
\text { "aprender a } \\
\text { aprender"; }\end{array}$ & $\begin{array}{l}\text { Inteligência pessoal } \\
\text { (inter e intrapessoal) } \\
\text { Inteligência lingüística } \\
\text { Inteligência lógica }\end{array}$ & $\begin{array}{l}\text { Solicitação de feedback (1) } \\
\text { Expressão Oral (1) } \\
\text { Pesquisas bibliográficas (2) }\end{array}$ \\
\hline & $\begin{array}{l}\text { Desenvolvimento } \\
\text { de trabalhos } \\
\text { individuais sem, } \\
\text { contudo, perder a } \\
\text { dimensão do todo; }\end{array}$ & $\begin{array}{l}\text { Inteligência } \\
\text { Intrapessoal } \\
\text { Inteligência lógica } \\
\text { Inteligência Lingüística }\end{array}$ & $\begin{array}{l}\text { Expressão Oral }(1,2) \\
\text { Expressão Escrita } \\
\text { Exercícios }(2) \\
\text { Solicitação de feedback }(1,2)\end{array}$ \\
\hline & $\begin{array}{l}\text { Capacidade de } \\
\text { expressão oral e } \\
\text { escrita; }\end{array}$ & $\begin{array}{l}\text { Inteligência pessoal } \\
\text { (inter e intrapessoal) } \\
\text { Inteligência lógica } \\
\text { Inteligência lingüística }\end{array}$ & $\begin{array}{l}\text { Exercícios (2) } \\
\text { Expressão Escrita }(1,2) \\
\text { Solicitação de feedback }(1,2) \\
\text { Pesquisas em assuntos } \\
\text { relacionados (2) } \\
\text { Reprodução de textos } \\
\text { escritos sobre o assunto (2) }\end{array}$ \\
\hline
\end{tabular}

(1) $\rightarrow$ pelo educador

* A leitura de textos, artigos, apostilas, livros, etc, estão incluídos na expressão escrita

(2) $\rightarrow$ pelo estudante 


\subsection{Seminário}

O seminário é um tipo especial de discussão que vem sendo utilizado com freqüência, cada vez maior, no ensino superior. Geralmente é utilizado como estratégia para o desenvolvimento de trabalhos em grupo, mas pode ser utilizado como trabalho individual.

"O seminário pode ser considerado a principal manifestação daquilo que se convencionou chamar de "métodos ativos", calcados na atividade e ação intelectual do aluno sobre o objetivo do aprendizado, utilizando o grupo de trabalho como meio de formação" (MOREIRA 1997, p.87).

Para GIL (1994) e LIBÂNEO (1994) seminário é uma estratégia indicada para ser usada ocasionalmente e eventualmente pode ser conjugada com outras, sendo adequada para semear, fertilizar idéias e desenvolver raciocínios lógicos e críticos, em pequenos grupos. Essa justificativa advém do próprio nome que tem origem latina $\rightarrow$ semem: em português $=$ semente.

Por ser uma estratégia de ensino em pequenos grupos, os estudantes tendem a desenvolver um nível diferenciado de raciocínio, enquanto tornamse mais tolerantes com as diferenças individuais dos colegas que também participam dessa atividade.

O objetivo imediato dessa estratégia é levar os envolvidos no processo de aprendizagem a falar e a pensar criticamente sobre determinado tema objetivando o crescimento pessoal e o desenvolvimento de competências.

BROWN E ATKINS ${ }^{4}$ (1991) apud MOREIRA (1997) definem como objetivos do seminário:

$\checkmark$ Desenvolvimento de habilidades de comunicação.

${ }^{4}$ BROWN, G. \& ATKINS, M. (1991). Effective teaching in Higher Education. Grã-Bretanha, Routledge apud MOUREIRA (1997). Didática do ensino superior: técnicas e tendências. São Paulo. Pioneira. p. 84. 
$\checkmark$ Desenvolvimento de habilidades intelectuais e profissionais.

$\checkmark$ Crescimento pessoal dos estudantes e do educador.

O seminário é uma estratégia de ensino que gira em torno de um tema a ser estudado em profundidade e a partir de diferentes ângulos. Após uma pesquisa minuciosa, os participantes se reúnem para sintetizar as informações obtidas, chegando a alguma conclusão.

Segundo MASETTO (1995), o seminário se enquadra nos objetivos do ensino nos cursos de graduação e de pós-graduação por ter como meta:

1) Preparar a incorporação ativa de responsabilidades nas tarefas particulares de estudo;

2) Iniciar a colaboração intelectual;

3) Preparar para investigação e abstração conclusiva e crítica de assuntos relacionados e paralelos a contexto pessoal e profissional em que se está inserido no momento e que, futuramente, se inserirá.

Ao optar por essa estratégia deve-se ter em mente que através dela visa-se ao ensino dos instrumentos necessários para os trabalhos intelectuais, colocando os estudantes em contato com fontes bibliográficas e com a responsabilidade de analisar os fatos e problemas implícitos ao tema, além de procurar incutir o hábito de discussão de idéias.

\subsubsection{O planejamento do seminário}

O seminário é constituído por um grupo de pessoas que se reúnem sob a coordenação de um "especialista" no assunto, com o objetivo de estudar um tema, a partir da apresentação por um dos integrantes do grupo (GIL, 1994).

Nos cursos superiores e de pós-graduação o seminário, geralmente, se desenvolve na sala de aula e tem como coordenador o próprio educador, responsável 
pela disciplina. Ele elaborará um calendário para as apresentações, orientará acerca da procura por fontes especializadas do assunto, e coordenará a apresentação.

É uma estratégia extremamente útil no tocante a atingir objetivos que permeiam, relacionados ao desenvolvimento de posturas, capacidade técnica e raciocínio crítico pois possui uma característica forte de ser uma estratégia que funciona mais como uma fonte de idéias do que simplesmente como um meio de informação alternativa (GIL, 1994).

Muitas vezes, devido à imaturidade no tocante as atividades que são inerentes à estratégia, é importante que o educador auxilie no processo de organização do material e das idéias a serem apresentadas.

A partir do conhecimento, por parte do educador, do real objetivo da estratégia é importante certo cuidado em relação à preleção feita do tema e da orientação, quanto à forma de pesquisa e apresentação. Após discussão e apresentação, os comentários finais feitos pelo educador deverão possuir uma natureza crítica em relação à postura e ao tema sobretudo, uma postura orientadora para que não ocorra a descrença do real valor do seminário, enquanto estratégia de ensino e aprendizagem de técnicas, teorias e habilidades (MOREIRA, 1997).

Dessa forma, os integrantes perceberão seu real crescimento em relação ao tema (conhecimento técnico) e às suas competências pessoais estimuladas e desenvolvidas.

O processo inicia-se com uma pesquisa sobre um tema específico. Durante essa atividade de leitura sobre o assunto estará sendo desenvolvida também a capacidade técnica, uma vez que estarão sendo aprimorados conhecimentos pertinentes à área de atuação profissional do indivíduo.

Durante a organização das idéias obtidas a partir de uma pesquisa sobre o tema e a preparação das apresentações, com a devida coordenação, o grupo será incentivado a aprimorar capacidades pessoais como concentração, abstração de tópicos e temas relacionados, 
desenvolvimento da sequenciação de idéias, além da capacidade de expressão.

O objetivo central de um seminário não é o "expor um tema", mas sim criar condições para que seja possível uma discussão crítica e concisa sobre o tema. Para tanto, todos que efetivamente participarem, devem ter claro a relevância do tema dentro do contexto educacional e profissional inserido.

Uma vez que deverá haver uma discussão sobre o assunto, após a apresentação, convém que os trabalhos a serem apresentados sejam entregues por escrito, para todos os componentes da sala e com antecedência.

Segundo GIL (1994) e MOREIRA (1997) os seminários, quando bem conduzidos, mostram-se úteis sobretudo para:

$\checkmark$ identificar problemas;

$\checkmark$ reformular problemas a partir de ângulos diferentes;

$\checkmark$ propor pesquisas para solucionar problemas;

$\checkmark$ acompanhar desenvolvimentos de pesquisas específicas;

$\checkmark$ comunicar resultados obtidos em pesquisas;

$\checkmark$ apreciar e avaliar resultados obtidos em pesquisas.

Há inúmeras variações da aplicação dessa estratégia, sendo que muitas perdem o foco do desenvolvimento e não possibilita um maior entendimento sobre o tema, ou pelo menos não ocorre de forma explícita. Essas situações ocorrem principalmente quando os seminários são utilizados de forma simples para a exposição de um assunto, sem que tenha havido a leitura ou conhecimento prévio deste pelos demais integrantes da sala e quando o tempo para discussão e conclusão, onde deverá haver um maior envolvimento dos estudantes com o conteúdo, não é dimensionado corretamente ou inexistente. 


\subsubsection{Vantagens da utilização do seminário}

O valor real formativo da utilização da estratégia está em fazer que os estudantes enfrentem os temas/problemas abordados de forma ativa, dirigindo seu processo de aprendizagem, perguntando e respondendo a cerca da questão a ser discutida e, não, em fazer com que eles cheguem a conclusões definitivas (GIL, 1994).

Segundo MOREIRA (1997:89), "a vantagem do seminário, enquanto método de estudo e atividade didática, está na formação da capacidade de aprender, preparando o aluno para se tornar um aprendiz independente. Para um seminário ser bem-sucedido, espera-se que o docente e discentes compartilhem responsabilidades, pois ambos têm tarefas a cumprir e trabalhos a realizar".

Algumas limitações da estratégia estão diretamente ligadas à habilidade e disposição do educador que deverá estar preparado para estabelecer um ambiente propício à discussão, especialmente quando o grupo de alunos é tímido ou reservado, assim como deverá ter a habilidade de motivar todos os estudantes a participarem e não apenas aqueles mais expansivos.

A falta de maturidade para elaboração dos trabalhos em equipe e a falta de maturidade intelectual de absorção de um novo conteúdo sem a efetiva participação do docente podem confundir e desorientar os estudantes, por isso uma orientação mais próxima e de apoio por parte do docente pode auxiliar 0 aluno a enfrentar, situações de ensino não estruturadas, desenvolvendo-se tecnicamente e intelectualmente.

\subsubsection{Desenvolvimento da estratégia seminário - algumas sugestões}

Como o sucesso da estratégia também está relacionado com a forma como é apresentada e trabalhada com o grupo, poderá haver variações 
pessoais em relação à orientação e da organização da sala de aula para um melhor aproveitamento da técnica e um maior desenvolvimento técnico e corporal (posturas) de todos os envolvidos no processo.

MOREIRA (1997) e MASETTO (1985) sugerem quatro possibilidades de organização com a finalidade de abstrair o máximo possível da técnica de acordo com o posicionamento do coordenador do seminário.

1. Quando trabalhar com pequenos textos e de uma variedade de até três autores com visões distintas do mesmo tema, é sugerido que o educador continue sendo a FIGURA "mais importante" na operacionalização da técnica, sendo a maior parte da discussão feita através dele, com os estudantes se reportando diretamente a ele, a fim de esclarecer dúvidas e buscar novas informações (FIGURA 7.2).

Nesse modo é interessante que o educador possua algumas perguntas específicas do tema para dar maior dinamicidade à técnica porque pode haver uma passividade e um retraimento maior à medida que ele assuma a liderança da discussão do tema.

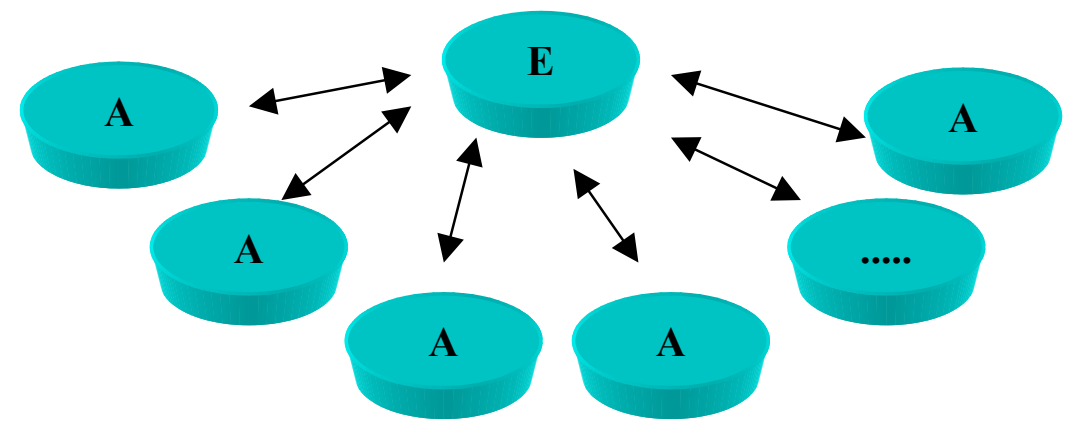

FIGURA 7.2: Seminário com o educador como coordenador: o educador (E) como coordenador do processo de discussão do tema perante aos estudantes $(A)$

2. Quando o assunto a ser abordado é diferente para cada grupo ou pessoa, o seminário deverá ser organizado em torno desse grupo ou pessoa, onde alguém ficará encarregado de coordenar a discussão 
temporariamente, cabendo ao educador intervir quando necessário ou apenas no fechamento do tema/problema.

Nesse modelo, ao final da estratégia, é o momento ideal para coordenar uma pequena análise sobre a postura do apresentador perante a sala e sua clareza, firmeza e coerência nas idéias e ações com a finalidade de orientá-los no aprimoramento de habilidades e posturas profissionais. (FIGURA 7.3).

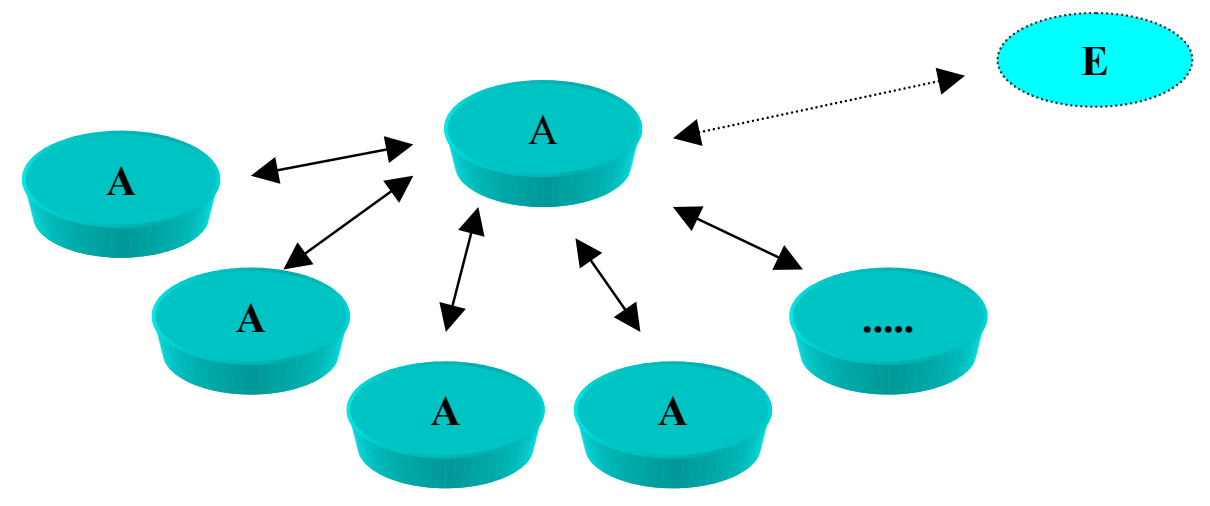

FIGURA 7.3: Seminário com o estudante como coordenador - O estudante (A) como coordenador do processo de discussão do tema perante aos outros estudantes, tendo o educador apenas como mais um integrante do grupo.

3. Quando os temas a serem abordados são complementares, é sugerido que o educador seja colocado como um dos participantes e a comunicação entre todos seja estabelecida numa base de igualdade, com diálogos ocorrendo entre todos. Nesse modo não há um coordenador específico da estratégia. Esse é o modo onde é necessário e há uma maior probabilidade de desenvolvimento da interação e cooperação, a expressão oral, assim como o discernimento crítico das idéias apresentadas (inteligência lingüística), a análise e conclusões das informações apresentadas (inteligência lógica) para que haja, efetivamente, o desenvolvimento intelectual dos estudantes. (FIGURA 7.4). 


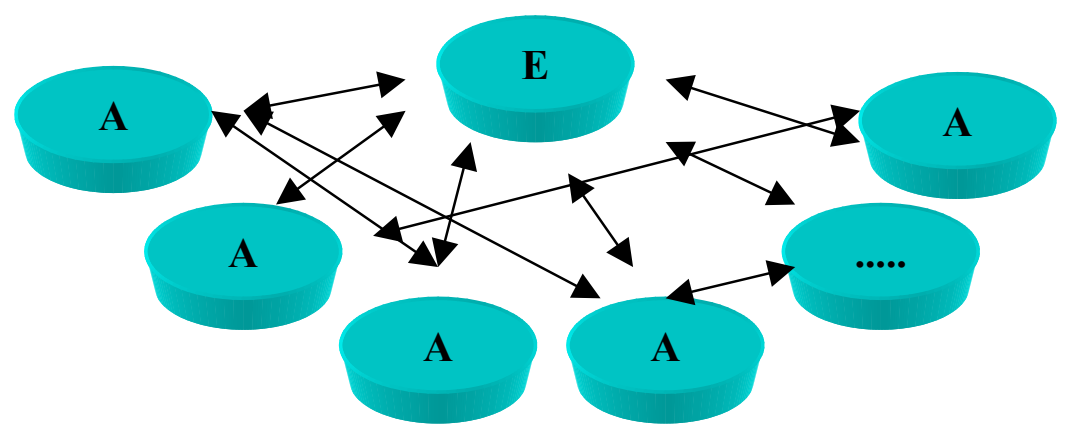

FIGURA 7.4: Seminário sem coordenador específico - O educador (E) é parte ativa do processo de explanação, onde todos possuem conhecimentos complementares e podem ser capazes de discutir com discernimento e complementação uns com os outros.

4. Esse modo é uma variante do modo demonstrado pelas FIGURAS 7.3 e 7.4 , onde o educador iniciaria o assunto a ser abordado para, posteriormente, ser conduzido pelo coordenador, que seria um dos estudantes. Caberá ao coordenador estabelecer as atividades a serem realizadas a partir de um roteiro por ele elaborado e apresentar sua reflexão pessoal.

Independentemente do modelo a ser escolhido, ou da criação de um novo modelo, de acordo com o público presente, é de responsabilidade do educador o fechamento da atividade relacionando-a com o conteúdo da disciplina, sua aplicação prática e o encadeamento lógico entre os assuntos abordados (SEVERINO, $1975^{5}$ apud MOREIRA, 1997).

O papel do educador é essencialmente de orientação. Consiste em coordenar as diversas atividades, orientando e guiando os alunos em todas as fases do processo.

Antes ou depois do desenvolvimento da apresentação perante a sala, poderão ser abordadas questões sobre como falar em público, gestos que deveriam ser minimizados nessas situações, como trabalhar o nervosismo

${ }^{5}$ SEVERINO A. J. (1975) Metodologia do Trabalho Científico: Diretrizes para o trabalho Didático- Científico na Universidade. São Paulo. Cortez \& Moraes Ltda apud MOREIRA (1994). Didática do ensino superior: técnicas e tendências. São Paulo. Pioneira. p. 92 e 93. 
ou a falta de confiança pessoal ao se expor no grupo. A consciência de que as críticas que deverão ser feitas pertencem ao assunto e, não, às pessoas integrantes do grupo de apresentação. Essa é uma conscientização importante uma vez que no mercado profissional, algumas vezes, serão vividos situações semelhantes e esse exercício e a explicação poderá ser de grande valia no decorrer da vida profissional.

Para um bom desenvolvimento da estratégia seminários, BROWN e ARTIKINS (1991) ${ }^{6}$ apud MOREIRA (1997) e GIL (1994) sugerem:

1)Arranjos dos assentos: geralmente é escolhido, de acordo com o que se queira em relação à interação entre educandos e educador. À distância entre estudantes e o educador, bem como os móveis podem influenciar essa interação. O círculo é aconselhável, mas o educador, deverá variar seu lugar a cada sessão. Geralmente estudantes mais falantes, tendem a se tornar mais tímidos quando sentados ao lado do educador, portanto um certo discernimento quanto ao local onde deverá permanecer durante a apresentação de um seminário é fundamental, por parte do responsável pelo processo de ensino;

2)Expectativas e regras gerais: o fato de que os estudantes não sabem muito bem o que se espera deles durante a atividade, pode dificultar e/ou prejudicar seu desempenho durante todo o processo de preparação, organização e apresentação. Por isso, é importante discutir as expectativas do educador e deles, de forma a se obter um acordo informal, baseado na liberdade de criação e apresentação por partes dos envolvidos no processo de aprendizagem;

3)Segurança: Deve se deixar claro que qualquer crítica ou comentário que possa ocorrer não deverá ser encarado de forma pessoal. Essa segurança possibilita aos estudantes a correr riscos e não se intimidarem no momento de contribuir. $\mathrm{O}$ reforço positivo enquanto grupo é fundamental

\footnotetext{
${ }^{6}$ BROWN, G. \& ATKINS, M. (1991). Effective teaching in Higher Education. Grã-Bretanha, Routledge apud MOREIRA (1997). Didática do ensino superior: técnicas e tendências. São Paulo. Pioneira. p. 84.
} 
para o bom andamento das discussões; esse reforço deverá ser explícito para a sala como um todo, pois nessa estratégia todos deverão contribuir. Cabe ao educador, com sua habilidade, evitar que a conversa degenere para discussões superficiais ou inócuas que não tragam um desenvolvimento técnico e pessoal.

Neste mesmo contexto, BROWN e ARTIKINS (1991) ${ }^{7}$ apud MOREIRA (1997) e GIL (1994) sugerem algumas habilidades que o educador deve procurar desenvolver para a estratégia de ensino em pequenos grupos da estratégia seminário:

$\checkmark$ Explicar: saber quando explicar é tão importante quanto saber como explicar. Muitas vezes a explicação se torna necessária após a apresentação do tema para desencadear uma discussão entre todos os integrantes da sala.

$\checkmark$ Questionar: como recurso para iniciar ou direcionar uma discussão sobre o tema o educador pode formular algumas questões para obter contribuições e construir conceitos ou conjecturas, pois o saber ouvir e responder coerentemente, dentro do que se é questionado ou esperado, é uma habilidade a ser desenvolvida pelos participantes. Nesse momento, o exemplo de perguntas corretas desencadeando respostas coesas torna-se importante dentro do processo.

$\checkmark$ Ouvir: ouvir corretamente pode ser um desafio em alguns momentos. Os seres humanos numa explicação oral, tendem a se "desligarem" durante o processo de explanação e/ou perceberem apenas as informações que coincidam com seus próprios pontos de vista. A coerência entre a linguagem oral e a corporal de quem está falando é fundamental para a perfeita assimilação da idéia central. Tentar minimizar a agitação dos braços, mãos e pernas é extremamente importante quando o

${ }^{7}$ BROWN, G. \& ATKINS, M. (1991). Effective teaching in Higher Education. Grã-Bretanha, Routledge apud MOREIRA (1997). Didática do ensino superior: técnicas e tendências. São Paulo. Pioneira. p. 85. 
objetivo é fazer com que a audiência foque no cerne da informação que está sendo compartilhada e não na pessoa responsável pela apresentação.

$\checkmark$ Responder: fornecer respostas às questões levantadas pelos alunos e acrescentar comentários com o intuito de manter o processo de discussão. O educador deve incentivar aos integrantes do grupo a desenvolverem essa habilidade; uma vez que é comum os estudantes transformarem o ensino em grupo num monólogo coletivo conduzido pelo docente. No que diz respeito a essa habilidade o educador deverá auxiliar os estudantes a organizarem suas respostas às questões colocadas pelo grupo, tornando-os cada vez mais independentes das opiniões e visões do docente.

Sumariar e Fechar: sumariar pode ser usado ao final de um subtópico ou ao final de um assunto com o intuito de conectar os pontoschaves e as ligações importantes, assim como de esclarecer os pontos e prioridades a respeito do assunto discutido, ao final, o coordenador da atividade deverá agradecer a participação de todos, terminando, formalmente atividade.

\subsubsection{Uso adequado do seminário e sua relação com a Teoria das Inteligências Múltiplas}

Por ter que elaborar textos escritos e expor resultados, essa estratégia oferece oportunidade de desenvolvimento, de uma forma diferenciada, das expressões oral e escrita e de desenvolvimento técnico intelectual de todos os envolvidos.

Idealmente o seminário deveria ser desenvolvido por mais de uma pessoa $^{8}$, o que possibilita o desenvolvimento constantes das inteligências pessoais, por " criar" um ambiente de ensino onde está presente, até mesmo de forma implícita, a colaboração.

\footnotetext{
${ }^{8}$ Num grupo, o número ideal de 5 participantes podendo chegar até 12 dependendo do tema a ser abordado.
} 
Essa é uma das estratégia que requer o mínimo de maturidade intelectual e é muito bem aceita por alunos que estão nos últimos anos dos cursos de graduação ou pós-graduação. Porém esta pode ser usada a qualquer momento, desde que o educador respeito os limites intelectuais dos estudantes e desenvolva uma boa estratégia de liderança e desenvolvimento da expressão oral, postural e intelectual dos envolvidos.

Outra característica básica dessa estratégia é o envolvimento do aluno no processo, ocupando-se com a realização de diversas tarefas: recorrendo às fontes bibliográficas indicadas, levantando e correlacionando novos dados, lendo e fazendo fichamento das leituras realizadas, elaborando trabalhos escritos e expondo suas idéias.

Dentro do contexto da utilização da estratégia o aspecto mais importante, segundo MOREIRA (1997) e MASSETTO \& ABREU (1985), é a criação de um espaço para discussão, sendo o centro dessa discussão um texto ou trabalho escrito, produzido pelos educandos, escolhido ou não pelo educador.

"Mesmo quando os estudantes organizam o seminário a partir de um texto indicado pelo professor isto não exime o aluno do trabalho de investigação. Nesse caso, caberá a ele trabalhar a partir do texto básico, buscando compreendê-lo e interpretá-lo, refletindo sobre as problemáticas nele implícitas" (MOREIRA, 1997, p. 89).

O educador deverá direcionar os textos que deverão ser preparados para os seminários, uma vez que pode surgir insegurança, por parte dos estudantes, quanto à forma "ideal" a ser apresentada.

Dentre as possíveis formas escritas a serem apresentadas, MEDEIROS (1997) e BARROS (2000) indicam que os textos a serem elaborados e entregues poderão ter a forma de:

Resumo é a condensação do texto, uma atividade de condensar as idéias principais ou centrais. Para realizar o resumo é necessário que tenha havido a leitura analítica que possibilite a síntese do texto. Essa síntese 
poderá ser feita com as palavras do autor ou do leitor, desde que a mensagem não seja alterada.

a) Orientações para a realização de um resumo:

$\checkmark \quad$ Não resumir antes de levantar e preparar as anotações das leituras;

$\checkmark$ Usar sempre frases breves, objetivas, acrescentando referencias bibliográficas e observações de caráter pessoal, se necessário.

b) O resumo se compõe das seguintes fases:

$\checkmark$ Ler e reler o texto procurando entendê-lo;

$\checkmark$ Procurar a idéia principal dos parágrafos;

$\checkmark$ Relacionar e ordenar as idéias principais;

$\checkmark$ Escrever a síntese, formando frases, com as idéias principais;

$\checkmark$ Verificar se a síntese está coerente com a mensagem do texto;

$\checkmark$ Redigir, com as próprias palavras, em bom estilo.

c)Estrutura: É a representação gráfica de um texto que foi lido. Pode ser realizada através de listagem numérica ou chaves, pressupondo-se que tenha havido compreensão das relações entre as partes e o entendimento do texto como um todo.

As estruturas possuem as seguintes características:

$\checkmark$ Fidelidade do original

$\checkmark$ Estrutura lógica

$\checkmark$ Flexibilidade e funcionalidade (em uma só olhada, pode-se ter idéia clara do conteúdo).

Resenha é a síntese geral, informativa e avaliativa sobre livros, capítulos, artigos das mais diferentes áreas do conhecimento e que serve, por conseguinte, para orientar as opções e o interesse do leitor em questão. É um tipo de redação técnica que deverá ocorrer, após a leitura de um único 
texto conciso sobre o assunto. Deve conter a descrição das credenciais do autor, o resumo da obra, conclusões, metodologias empregadas, um quadro de referências em que o autor se apoiou e uma avaliação crítica ou não sobre o tema (texto) lido e a descrição a quem a obra se destina.

Paper ou artigo é um documento que se baseia em pesquisa bibliográfica e em descobertas pessoais. Se o autor compilou informações sem fazer avaliações ou interpretações sobre elas, o produto de seu trabalho será um relatório, pois num paper espera-se o desenvolvimento de um ponto de vista acerca de um tema, uma tomada de posição definida e a expressão de um pensamento de forma original. Sempre deverá ser escrito na $3^{\text {a }}$ pessoa e, geralmente, tem como objetivo sua publicação nas atas ou anais do evento em que foi apresentado.

Fichamento, realizado a partir de leituras feitas, com um tema proposto. Não é um sumário ou índice das partes que compõem as leituras; mas, exposição abreviada das idéias dos autores. É uma citação, pelo leitor, com as próprias palavras, sendo mais uma interpretação do material lido. Não precisa obedecer a nenhuma estrutura: lendo sobre o assunto, o estudante faz anotações dos pontos principais, redige um resumo, com a essência do que foi lido.

O esclarecimento, por parte do educador, sobre a forma como deverá ser escrito o material a ser entregue é muito importante para que os estudantes se sintam mais seguros quanto ao direcionamento a tomar durante a leitura do(s) texto(s); e, conseqüentemente na forma como apresentá-los oralmente.

Os alunos durante o desenvolvimento do trabalho começam a descobrir sua própria maneira de "aprender a aprender", conforme vão vivenciando a necessidade de compreender os temas/problemas e a discorrer, sob a forma escrita ou oral sobre um determinado tema. Preferencialmente, o tema deverá ser abordado em grupo, independentemente do estudo ter sido realizado individualmente e a explanação e discussão ser em conjunto. 
Na TABELA 7.4, são apresentadas as atividades citadas acima e sua relação com a Teoria das Inteligências Múltiplas.

TABELA 7.4: Seminário, atividades e inteligências estimuladas

\begin{tabular}{|l|l|}
\hline \multicolumn{1}{|c|}{ Atividade } & \multicolumn{1}{|c|}{ Inteligência } \\
\hline $\begin{array}{l}\text { Vivenciando a necessidade de compreender os } \\
\text { temas/problemas para realização das tarefas } \\
\text { agregadas }\end{array}$ & $\begin{array}{l}\text { Inteligência } \\
\text { lingüística } \\
\text { Inteligência lógica; } \\
\text { Inteligências } \\
\text { pessoais }\end{array}$ \\
\hline Escrita ou oral sobre um determinado tema & $\begin{array}{l}\text { Inteligência } \\
\text { lingüística }\end{array}$ \\
\hline Explanação e a discussão dele junto ao grupo & $\begin{array}{l}\text { Inteligências } \\
\text { pessoais }\end{array}$ \\
\hline Conclusão e fechamento da estratégica. & Inteligência lógica \\
\hline
\end{tabular}

Muitas vezes, devido à imaturidade em relação às atividades que são inerentes à estratégia, é importante que o educador, numa primeira vez, auxilie no processo de organização do material, na escrita do material coletado e na forma como as idéias devem ser apresentadas.

Independentemente do modelo escolhido, o seminário pode ser dividido em cinco grandes fases, com atividades específicas:

Fase 1: Conhecimento e procura do material sobre o tema escolhido.

Fase 2: Organização das idéias centrais do material encontrado.

Fase 3: Redação do texto a partir das idéias principais dos materiais lidos.

Fase 4: Estruturar a apresentação do material redigido

Fase 5: Apresentar o trabalho para outras pessoas. 
Todas as fases estão correlacionadas e podem ocorrer, de forma organizada e concomitante.

Em cada uma dessas fases, atividades específicas são realizadas e podem ser associadas ao desenvolvimento da Teoria das Inteligências Múltiplas.

\section{Fase 1: Conhecimento do material sobre o tema escolhido}

Nesse momento os estudantes começarão a se familiarizar com o tema a ser trabalhado. Como essa estratégia prevê um conhecimento prévio sobre o assunto, nessa fase de reconhecimento, a procura e, efetiva pesquisa, bibliográfica pode ser um pouco mais trabalhosa, caso o educador tenha apenas escolhido o tema. Porém há sempre a possibilidade do educador direcioná-lo para um determinado autor, livro, capítulo ou artigo que tratará do tema.

A compreensão do(s) texto(s) requer maturidade no relacionamento desse tema aos já abordados por outras disciplinas (cursadas ou cursando), informações lidas em jornais, revistas, artigos científicos, etc. Nesse momento de compreensão e co-relação à inteligência lógica é altamente estimulada.

Como a pesquisa/leitura pode ser feita individualmente, a inteligência intrapessoal e a capacidade de aprender a aprender começam a ser estimuladas. Caso o trabalho seja realizado em grupo, no momento em que se começa a organização do material coletado (fase 2), a inteligência interpessoal começa a ser desenvolvida.

Caso essa atividade seja realizada em equipe, a inteligência interpessoal é estimulada desde do início do processo assim como as características de cooperação, respeito pela opinião dos outros (aprendendo ouvir), e a capacidade de defender, oralmente, um ponto de vista, a partir de um material previamente escolhido. 
$\mathrm{Na}$ TABELA 7.5 abaixo se pode ver todas as atividades sugeridas na fase e quais inteligências são estimuladas.

TABELA 7.5: Seminário: Conhecimento do material sobre o tema escolhido atividades e inteligências estimuladas

\begin{tabular}{|l|l|}
\hline \multicolumn{1}{|c|}{ Atividade } & \multicolumn{1}{c|}{ Inteligência } \\
\hline Familiarização do tema & $\begin{array}{l}\text { Inteligência lógica } \\
\text { Inteligência lingüística }\end{array}$ \\
\hline Pesquisar/ler individualmente & $\begin{array}{l}\text { Inteligência lógica } \\
\text { Inteligência lingüística } \\
\text { Inteligências Intrapessoal }\end{array}$ \\
\hline Pesquisar/ler em grupo & $\begin{array}{l}\text { Inteligência lógica } \\
\text { Inteligência lingüística } \\
\text { Inteligências Interpessoal }\end{array}$ \\
\hline
\end{tabular}

\section{Fase 2: Organização das idéias centrais do material encontrado}

Trata-se, definitivamente, do início da atividade em equipe. Essa fase de organização inicia-se com a discussão do que foi lido; deve ocorrer, portanto, depois de todos terem lido o(s) material(ais).

A leitura poderia até ter sido realizada individualmente mas na organização todos devem estar presentes, uma vez que começará a ser desenvolvido o trabalho escrito e a apresentação.

$\mathrm{Na}$ organização em grupo, características como cooperação e colaboração são fundamentais, assim como o respeito à opinião alheia. Esse modelo, caso seja realizado com seriedade pelo grupo, faz com que diversas inteligências sejam estimuladas simultaneamente, assim como a capacidade de aprender a aprender e o desenvolvimento técnico efetivo ocorrido pela leitura do tema.

Essa é a fase de discussão que dará início á leitura e estruturação do material escrito ser apresentado. 
$\mathrm{Na}$ TABELA 7.6 pode-se ver todas as atividades sugeridas na fase 2 e quais inteligências estimuladas.

TABELA 7.6: Seminário: Organização das idéias centrais do material encontrado - Atividades e inteligências estimuladas

\begin{tabular}{|l|l|}
\hline \multicolumn{1}{|c|}{ Atividade } & \multicolumn{1}{c|}{ Inteligência } \\
\hline Discutir o que foi compreendido & $\begin{array}{l}\text { Inteligência lógica } \\
\text { Inteligência lingüística } \\
\text { Inteligências pessoais (inter e intrapessoal) }\end{array}$ \\
\hline Organizar as idéias centrais & $\begin{array}{l}\text { Inteligência lógica } \\
\text { Inteligência lingüística } \\
\text { Inteligências pessoais (inter e intrapessoal) }\end{array}$ \\
\hline Estruturar o material a ser & $\begin{array}{l}\text { Inteligência lógica } \\
\text { Inteligência lingüística }\end{array}$ \\
escrito & Inteligências pessoais (inter e intrapessoal) \\
\hline
\end{tabular}

\section{Fase 3: Redigir a partir das idéias principais dos materiais lidos}

Após a coleta e discussão das idéias centrais do texto, é começada a redação do material, de acordo com o sugerido pelo educador.

Nesse momento deverá estar claro que tipo de material escrito o educador deseja - resumo, resenha, fichamento, artigo, etc.

A redação poderá ser realizada por uma única pessoa uma vez que todos participaram da estruturação e deve estar coerente com a posição do grupo sobre o assunto. O ideal é que todos os integrantes da equipe participem do processo de redação, sugerindo novas e melhores palavras, expressões e coordenando a formatação do trabalho a ser entregue, assim estimulando a inteligência lingüística, pessoal e lógica.

A apresentação deverá ser estruturada a partir do texto a ser entregue e a participação da equipe inteira torna todos aptos a apresentarem e 
responderem a qualquer pergunta sobre o tema, bem como auxiliar no fechamento feito pelo educador.

Como o tema deverá estar relacionado com o objetivo da disciplina, a participação de todos no processo assegura o desenvolvimento técnico e pessoal de cada um.

Cabe ao educador, de forma sutil, mostrar as vantagens profissionais da participação de todos no processo, os benefícios da aquisição do conhecimento, do desenvolvimento da capacidade de trabalhar em equipe, da habilidade de leitura e escrita e das capacidades pessoais de respeito à opinião e conduta do outro.

$\mathrm{Na}$ TABELA 7.7, pode-se ver todas as atividades sugeridas e as inteligências estimuladas.

TABELA 7.7: Seminário: Redigir a partir das idéias principais dos materiais lidos - atividades e inteligências estimuladas

\begin{tabular}{|l|l|l|}
\hline \multicolumn{1}{|c|}{ Atividade } & \multicolumn{2}{|c|}{ Inteligência } \\
\hline \multirow{2}{*}{ Redação do material } & $\begin{array}{l}\text { Inteligência lingüística } \\
\text { Inteligência lógica } \\
\text { Inteligências intrapessoal }\end{array}$ & $\begin{array}{l}\text { Inteligência } \\
\text { interpessoal }\end{array}$ \\
\hline
\end{tabular}

\section{Fase 4: Estruturar a apresentação do material redigido}

Essa fase consiste em reler o material escrito e organizar o modo como será apresentado o trabalho.

Nesse momento deverá ser discutido se o trabalho será apresentado por uma única pessoa ou vários integrantes e quais os recursos ${ }^{10}$ a serem utilizados.

\footnotetext{
${ }^{9}$ Caso todos os integrantes do grupo participem do processo de redação

${ }^{10}$ Recursos multimídia, transparências, lousa, giz, etc.
} 
Caso a apresentação ocorra com a participação de vários integrantes a coerência do assunto e das partes que compõem o todo ocorrerá de forma eficiente se todos tiverem participado ativamente das fases anteriores, ou seja, se todos tiverem uma visão geral sobre o assunto a ser discutido.

Esse processo garante que a atividade de apresentação não se transforme numa "enorme colcha de retalhos" entre os participantes e assegura a compreensão do tema pelo público que participará da apresentação.

Na TABELA 7.8 pode-se ver as atividades sugeridas e as inteligências estimuladas.

TABELA 7.8: Seminário:Estruturar a apresentação do material redigido atividades e inteligências estimuladas

\begin{tabular}{|c|c|c|}
\hline Atividade & \multicolumn{2}{|c|}{ Inteligência } \\
\hline $\begin{array}{l}\text { Estruturação da } \\
\text { Apresentação }\end{array}$ & \begin{tabular}{|l} 
Inteligência lingüística \\
Inteligência lógica \\
Inteligências intrapessoal
\end{tabular} & $\begin{array}{l}\text { Inteligência } \\
\text { interpessoal }^{11}\end{array}$ \\
\hline
\end{tabular}

\section{Fase 5: Apresentar o trabalho para outras pessoas.}

Esse é o momento "máximo" de toda estratégia.

Geralmente é o momento de maior insegurança por parte do grupo por não saber exatamente como deverá realizar a apresentação. Cabe ao educador responsável pela disciplina, explicar e exemplificar o modo como uma apresentação deve ocorrer.

Algumas orientações podem facilitar a atividade de apresentação como, durante a apresentação, não passar grande parte do tempo lendo o material redigido, não ficar parado no mesmo local (o caminhar minimiza a

\footnotetext{
${ }^{11}$ Caso todos os integrantes do grupo participem do processo de redação
} 
ansiedade), usar um conjunto de diferentes recursos para exemplificar, cuidar da aparência física pois todas as atenções serão dirigidas ao expositor, falar num tom adequado para que todos possam ouvir, procurar não utilizar gírias e procurar usar expressões específicas da área. É ideal que seja realizado previamente um discurso de como essa atividade é semelhante à atividade diária de algumas empresas, para que o conteúdo (tema) trabalhado seja valorizado, para o desenvolvimento da maturidade e para a aquisição de conhecimento profissional.

Caso o educador ache pertinente, poderá ser negociado, com o grupo, que, após cada apresentação e fechamento do tema, ocorra um momento onde todos deverão dar sugestões de como evitar problemas nas próximas apresentações, com base na análise das falhas ocorridas. Nessa negociação deverá ficar claro que todas as críticas e sugestões serão a respeito da postura durante a apresentação e dos recursos utilizados e não sobre o assunto abordado ou sobre quem o apresentou. Dessa forma, além das inteligências estimuladas pela apresentação, a postura profissional dos integrantes também será aprimorada.

$\mathrm{Na}$ TABELA 7.9 podem-se ver as atividades sugeridas $\mathrm{e}$ as inteligências estimuladas durante a atividade de apresentação do tema.

TABELA 7.9: Seminário: Apresentar o trabalho para outras pessoas: atividade e inteligências estimuladas

\begin{tabular}{|l|l|}
\hline \multicolumn{1}{|c|}{ Atividade } & \multicolumn{1}{c|}{ Inteligência } \\
\hline $\begin{array}{l}\text { Apresentação do } \\
\text { tema }\end{array}$ & $\begin{array}{l}\text { Inteligência lingüística } \\
\text { Inteligência lógica } \\
\text { Inteligências pessoais (inter e intrapessoal) } \\
\text { Inteligência Corporal }\end{array}$ \\
\hline
\end{tabular}

A atividade de seminário, quando bem direcionada, dá suporte ao desenvolvimento de habilidades técnicas e pessoais. Engloba, dentro do 
contexto de sala de aula, atividades que deverão ocorrer no mercado profissional, assim como posturas e capacidades exigidas a uma pessoa que deseja participar ativamente desse mercado, sem contudo esquecer do desenvolvimento técnico.

Por possuir uma parte da atividade realizada extraclasse o senso de responsabilidade e disciplina são características, implicitamente, aprimoradas pela estratégia de seminários.

\subsection{Projeto}

“A idéia de projetos é velha como o homem" (AGUAIO, 1986:78).

Fora da atividade acadêmica a vida intencional do jovem, criança e adulto se resume numa sucessão de projetos, que cada qual concebe e executa com maior ou menor êxito, em conformidade com os recursos, grau de inteligência e iniciativa, como, por exemplo, preparar uma viagem, preparação de uma festa, redação de uma carta, desenvolvimento de uma atividade acadêmica, etc.

Segundo NÉRICI (1992), a estratégia de projeto consiste em levar a pessoa, individualmente ou em grupo, a projetar algo concreto e executá-lo de forma organizada e planejada.

Segundo o mesmo autor, ele teve origem por volta de 1918, quando W.I. Kirlpatric, aproveitando a análise do pensamento feita por John Dewey, imaginou uma forma concreta de ensinar.

A diferença básica entre eles é que Dewey procurava atuar mais no campo do intelecto, o de Kilpatrick procurava atuar mais no campo da prática, da realização efetiva.

Dessa forma, pode-se dizer que a estratégia de projeto é uma atividade que se desenvolve diante de uma situação problemática, concreta, real, e que busca soluções eficazes e práticas. A estratégia lida mais com 
práticas do que com idéias. Um exemplo de atividades que lidam mais com idéias do que com a prática é a conhecida como estudo de casos.

Para que se atinja os objetivos do projeto, é necessário que os educandos executem as atividades, com a assistência de um coordenador, que deve, gradativamente, ir se retirando da coordenação, conforme os grupos de pessoas atinjam certo grau de maturidade e autoconfiança para criarem seus próprios métodos de execução.

Segundo NÉRICI (1992) e LOURENÇO (1978) os princípios fundamentais do projeto, que justificam sua utilização no processo de ensino de terceiro grau, são:

$\checkmark$ A adequação do trabalho ao nível do desenvolvimento intelectual e prático;

$\checkmark$ O respeito pela personalidade e habilidades individuais;

$\checkmark$ A separação da atividade prática da teórica do profissional a ser formado;

$\checkmark$ A responsabilidade intelectual usada como instrumento de adaptação ou ajustamento mental na execução de atividades e tarefas variadas e definidas.

A estratégia de projeto, por ser uma atividade coordenada, intencional e com propósitos definidos, transforma atitudes durante o ensino. O ser passivo e dócil, que trabalha "a voz de comando", converte-se em um ser ativo, que concebe, prepara e executa o próprio trabalho, tendo como guia, o educador, quando necessário.

O projeto deve possuir um valor educativo que exemplifica a ligação da teoria à prática e deve ter como foco a formação sócio-psico-cultural e profissional e do homem.

A estratégia de projeto leva a produção concreta, mas racionalizada, com propósito que exige, necessariamente, a ação munida de pensamento, com a finalidade de resolver um problema; ou seja, vencer um obstáculo, uma situação de perplexidade ou outra dificuldade qualquer que tem como 
característica a descoberta pessoal simplesmente. Durante o desenvolvimento da atividade, deve-se seguir os princípios da teoria relacionada, como condição primordial para o domínio da situação e execução da tarefa.

Nesse contexto a estratégia de projeto e suas habilidades agregadas se liga diretamente ao conceito da Teoria das Inteligências Múltiplas, e mais precisamente à definição de inteligência que segundo GARDNER (1995), é a capacidade de resolver problemas.

\subsubsection{Objetivo da estratégia projeto}

Dentre os vários objetivos da estratégia de projeto, AGUAIO (1986), NÉRICI (1992) citam:

a)Levar o educando a passar por uma situação autêntica de vivência e experiência;

b)Levar a formular, individualmente, propósitos definidos e práticos em direção à execução das atividades relacionadas;

c) Estimular o pensamento prático;

d)Estimular a capacidade de trabalhar em equipe;

e)Apreciar concretamente a necessidade da cooperação;

f) Dar oportunidade para comprovação de teorias, por meio da aplicação;

g)Convencer o educando de que ele pode, desde que raciocine e atue adequadamente, resolver qualquer problema, por mais difícil que se pareça num primeiro momento;

h)Estimular a iniciativa, a autoconfiança e o senso de responsabilidade.

O ensino por projeto educa, com anuência, à vontade do educando, pois o coloca como ser agente e responsável pelo seu próprio processo de 
aprendizagem e vai, efetivamente, além das teorias a serem assimiladas pela disciplina, pois agrega, posturas, comportamento e intelectualidade "prepara para a vida".

Para LOURENÇO (1978), "Preparar para a vida" é colocar o indivíduo em condições de projetar, de procurar meios de realização para seus próprios empreendimentos e de realizá-los, verificando pela própria experiência o valor das concepções que estejam utilizando, assim, a partir da estratégia de projetos haverá crescimento, enquanto ser humano ativo, dos educandos.

\subsubsection{Classificação da estratégia projeto}

Projetos podem durar horas, dias ou apenas minutos como, por exemplo, a atividade de se escrever um oficio solicitando verba para uma atividade complexa, remunerada. Pode incluir números variados de pessoas e visa a desenvolver diferentes habilidades - de manuais a intelectuais apesar de que, independentemente do projeto e/ou tema, na realização, a estruturação do pensamento se faz necessária; portanto, esta atividade sempre engloba características do intelecto humano.

O número de integrantes num grupo de projeto depende da complexidade da atividade. Independentemente do projeto ele deverá sempre ser apresentado ao grupo/classe com forma de estímulos a novos projetos.

Independentemente do tipo de projeto, deverá haver um cuidado no dimensionamento correto do tempo de desenvolvimento e da disponibilidade de coordenação por parte do educador.

Segundo AGUAYO (1986) e LOURENÇO (1978), os projetos podem ser classificados, independentemente da sua complexidade, em:

1)CONSTRUTIVO - quando se propõem a realizar algo de concreto, que venha atender a alguma necessidade do meio ou demonstrar a execução de algo novo; 
2)ESTÉTICO - quando a atividade engloba projetos relacionados à satisfação estética, como é o caso de algo relacionado à música, pintura, decoração, etc.

3)APRENDIZAGEM - quando se propõe a levar o educando a adquirir conhecimentos e habilidades ou demonstrar praticamente a objetividade da teoria.

4)SOCIAL - quando se propõe a levar a efeito algo que reverta em benefícios comunitários.

A classificação dos projetos está diretamente ligada ao tema a ser proposto e não à disciplina devido à possibilidade da interdisciplinaridade.

\subsubsection{Desenvolvimento da estratégia projeto}

Embora, no geral, todos projetos possuam as mesmas etapas, não há uma formalidade específica aceita a ser rigorosamente seguida durante o desenvolvimento da estratégia, uma vez que o trabalho do pensamento não segue uma seqüência formal.

A não existência da formalidade recai sobre o fato de não importar por onde se começa o desenvolvimento de um projeto, sempre que necessário os educandos voltam a etapas anteriores para a confirmação de suas hipóteses.

Existem fases predominantes como a de observação e associação do tema proposto aos conhecimentos adquiridos, mas o início e o desenvolvimento está diretamente ligadas às características pessoais e intelectuais da equipe responsável pela execução.

Segundo NÉRICI (1992), LOURENÇO (1978) e AGUAYO (1986), para que os projetos atinjam seus propósitos educativos devem ser propostas algumas diretivas:

$\checkmark$ Deve estar em conformidade com os objetivos da disciplina. 
$\checkmark$ Deve vir ao encontro dos interesses individuais e coletivos de todos os envolvidos no processo de aprendizagem.

$\checkmark$ Deve estar diretamente ligado ao desenvolvimento de habilidades técnicas e intelectuais.

Todo projeto é, em essência, um ensino globalizado, uma vez que requer várias habilidades - da expressão oral e escrita ao raciocino lógico para a elaboração de um plano de ação.

A interdisciplinaridade se mostra ativa; a responsabilidade e a disciplina são fundamentais durante o desenvolvimento, sem esquecer que essas características, num primeiro momento, devem ser estimuladas pelo educador, que, com sua experiência, deve estar presente durante todas as fases dos primeiros projetos a serem desenvolvidos, como forma de ajudar os educandos na formação de uma linha de ação e postura de pesquisa, análise das hipóteses e apresentação dos resultados. Durante essa atividade os envolvidos assumem de forma consciente a participação no processo de ensino/aprendizagem.

Existem, segundo LEITE (1996), etapas para o desenvolvimento de um projeto, e elas podem ser agrupadas em três grandes grupos:

a) Problematização, também chamada de organização inicial do projeto: É o ponto de partida, o momento detonador do projeto. Desse passo de organização depende toda o desenvolvimento do projeto. Os educandos possuem um conhecimento prévio, hipóteses explicativas, concepções sobre o mundo. E é a partir desse conhecimento que a intervenção pedagógica precisa partir; pois, dependendo do nível de compreensão inicial, o processo toma caminhos diferentes. Nessa fase de problematização, deverão ser detectados quais os conhecimentos prévios assimilados que ajudarão na execução do projeto, assim como a organização do desenvolvimento pelo grupo.

b) Desenvolvimento, também chamada de estratégias para atingir objetivos e/ou realização do projeto: Nesse momento criam-se as estratégias para buscar respostas às questões e hipóteses levantadas. Aqui deverão 
ser levantadas as hipóteses, rever e comparar pontos de vistas, colocar-se novas questões, deparar-se com outros elementos. Nesse processo poderão ocorrer descobertas que levarão ao desequilíbrio das hipóteses iniciais.

c) Síntese e/ou apresentação: Em todo processo, as convicções iniciais vão sendo superadas e outras mais complexas vão sendo construídas. As novas aprendizagens passam a fazer parte dos esquemas de conhecimento e vão servir para outras situações de aprendizagem.

Dentro dessas macros etapas, considerações de LOURENÇO (1978), NÉRICI (1992) e AGUAYO (1986) complementam as divisões, explicitando o papel dos responsáveis (o educador, o educando ou ambos) no desenvolvimento do projeto, em momentos distinto. TABELA 7.10.

Como mencionado não há um rigor formal dos passos e nem todos os projetos passam sempre pelas fases referidas. É importante ressaltar que há projetos executados sem nenhuma coordenação ou planejamento do processo, o que significa que os integrantes do grupo não possuem uma estratégia definida para execução dessas atividades sendo necessário, a cada novo desafio, iniciar o processo sem considerar experiências e planejamento utilizados em atividades semelhantes.

A importância do planejamento e da criação das estratégias para a execução das atividades deve ser esclarecida pelo educador para que haja a conscientização de como isso pode auxiliar na construção de padrões para resolução de atividades semelhantes.

Esses padrões deverão ser flexíveis o suficiente para que a criatividade e iniciativa particular de cada pessoa/grupo se manifestem constantemente gerando novas formas mais eficazes de realização de tarefas complementares ou semelhantes. 
TABELA 7.10: Projeto - Etapas de um projeto e responsáveis pelo desenvolvimento

\begin{tabular}{|c|c|c|c|}
\hline \multirow[t]{2}{*}{ ATIVIDADE } & \multicolumn{3}{|c|}{ RESPONSÁVEL PELA EXECUÇÃO DA ATIVIDADE } \\
\hline & $\begin{array}{l}\text { Educando } \\
\text { (individualment } \\
\text { e) }\end{array}$ & $\begin{array}{c}\text { Educador } \\
\text { (individualment } \\
\text { e) }\end{array}$ & $\begin{array}{l}\text { Educando e } \\
\text { Educador } \\
\text { (simultaneamente) }\end{array}$ \\
\hline \multicolumn{4}{|l|}{ Problematização } \\
\hline Selecionar e elaborar o tema do projeto & $\mathrm{X}$ & $\mathrm{X}$ & $\mathrm{X}$ \\
\hline Planejar os detalhes para o desenvolvimento do projeto. & $\mathrm{X}$ & $\begin{array}{l}\text { Coordenador } \\
\text { Processo }\end{array}$ & \\
\hline Escolher o passo inicial para o desenvolvimento & $\mathrm{X}$ & $\begin{array}{l}\text { Coordenador } \\
\text { Processo }\end{array}$ & \\
\hline \multicolumn{4}{|l|}{ Desenvolvimento } \\
\hline $\begin{array}{l}\text { Recolher os dados do problema ou fatos de uma situação de acordo com a } \\
\text { estratégia planejada. }\end{array}$ & $\mathrm{X}$ & & \\
\hline $\begin{array}{l}\text { Observar e examinar em seguida esses fatos para situar ou esclarecer a } \\
\text { questão proposta. }\end{array}$ & $\mathrm{X}$ & & \\
\hline Elaborar uma hipótese ou solução possível. & $\mathrm{X}$ & & $\mathrm{X}$ \\
\hline Escolher uma das hipóteses elaboradas. & $\mathrm{X}$ & & \\
\hline $\begin{array}{l}\text { Verificar a confirmação da hipótese e sua aplicação, assim como observar a } \\
\text { possibilidade dessa hipótese indicar novas pesquisas e projetos e } \\
\text { apresentação dos resultados à classe/educador }\end{array}$ & $\mathrm{x}$ & & $\mathrm{X}$ \\
\hline $\begin{array}{l}\text { Coletar informação e selecionar o material necessário para a execução das } \\
\text { diversas fases do planejamento e da comprovação das hipóteses }\end{array}$ & $\mathrm{X}$ & & \\
\hline Executar as tarefas previstas & $\mathrm{X}$ & & \\
\hline \multicolumn{4}{|l|}{ Síntese/ Apresentação } \\
\hline Apresentação do projeto/conclusão à sala & $\mathrm{X}$ & & \\
\hline $\begin{array}{l}\text { Receber a apreciação do educador a respeito do trabalho realizado e } \\
\text { considerações em torno de como o mesmo se desenvolveu. }\end{array}$ & $\mathrm{X}$ & & \\
\hline Caso seja pertinente, expor o projeto para diferentes públicos. & $\mathrm{X}$ & & $\mathrm{X}$ \\
\hline
\end{tabular}

TABELA 7.10: Projeto - Etapas de um projeto e responsáveis pelo desenvolvimento 


\subsubsection{Orientação didática para o desenvolvimento de projetos}

Dentre os vários direcionamentos didáticos pedagógicos que podem ser seguidos para o desenvolvimento e planejamento de um projeto, entre eles:

$\checkmark$ Ao planejar uma situação de aprendizagem, o educador deve levar em conta que o conteúdo a ser apreendido não se restringe aos conceitos ou fatos que devem ser apreendidos e dominados pelos educandos. Procedimentos e atitudes, normas e valores relacionados a determinado tema, pertinente ao assunto da disciplina, são passíveis de serem apreendidos e desenvolvidos e devem estar previstos.

$\checkmark$ Os conhecimentos anteriores sobre os assuntos relacionados ao tema não devem ser negligenciados. Pois eles deverão buscar novas informações e novas formas de desenvolver os projetos baseados e direcionados por temas e informações correlacionadas e sobre procedimentos de pesquisas e estudos já conhecidos.

$\checkmark$ Todo novo elemento/dados modifica, de forma esperada, conhecimentos anteriores e funciona como base para conhecimentos posteriores. Não se pode esquecer que essa mudança de conhecimento ocorre de forma globalizada, não são estanques e esse relacionamento deve ser positivamente incentivado pelo idealizador (educador) do tema do projeto.

$\checkmark$ Como projetos não são empreendimentos únicos e não são passíveis de serem reproduzidos na íntegra, o educador deve propiciar ambiente para que os educandos expressem curiosidades, definam-se, de maneira coerente, até onde se pretende chegar com a pesquisa, para a execução das tarefas relacionadas ao tema, de uma forma clara baseada no objetivo do trabalho e nos parâmetros existentes para posterior avaliação.

$\checkmark$ Deve-se incentivar que o trabalho seja registrado passo a passo, a fim de que se produza a organização de uma memória de etapas percorridas 
e do percurso da produção em equipe, objetivando a criação de um parâmetro inicial para desenvolvimentos de atividades que sigam o mesmo modelo ${ }^{12}$.

$\checkmark$ Diferentes fontes de informação devem ser utilizadas. No momento inicial, é necessário que o educador direcione toda a pesquisa para bibliografias específicas e incentive a procura de novas fontes de fácil acesso, como entrevistas com pessoas conhecidas que possam ter informações sobre o assunto, vídeos, filmes, eventos, experiências pessoais, etc.

$\checkmark$ Sempre que for possível deve haver o incentivo de utilização de material produzido pela própria instituição de ensino - apostilas, trabalhos escolares, monografias, dissertações, teses, etc., com a finalidade de propiciar um maior conhecimento de temas abordados relacionados e comprovar a seriedade com que os projetos devem ser realizados para também servirem de material para novas atividades a serem desenvolvidas por outros estudantes.

As sugestões acima citadas podem ser usadas para direcionar 0 desenvolvimento e coordenação do projeto a ser executado, tendo a avaliação final como meio oficial para regular o desempenho dos integrantes e qualidade do trabalho produzido. Essa avaliação é de vital importância e deverá ser realizada constantemente e incidir tanto sobre a aprendizagem quanto sobre a eficácia do tema e do projeto executado, enquanto estratégia de ensino de uma disciplina específica.

\footnotetext{
${ }^{12}$ Nesse momento pode surgir um novo tópico a ser abordado numa aula presencial. A orientação e análise, por todos, dos procedimentos descritos pelos grupo se chegar num consenso sobre qual as melhores estratégias desenvolvidas e como foram estruturadas e planejadas, adicionando, efetivamente, ao conteúdo programático, o desenvolvimento do raciocínio crítico, da cooperação e da elaboração e análise de atividades realizadas.
} 


\subsubsection{O que deve conter o planejamento de projeto}

Segundo LEITE (1996), SMOLKA (1988) e JOLIBERT (1994), o planejamento eficaz de um projeto e/ou de um tema para um projeto deve incluir diretivas de motivação para a execução mais compromissada por partes dos educandos, além da clareza das seguintes etapas durante a escolha de uma atividade:

a)Apresentação - o tema deve ser apresentado em linhas gerais o produto a ser desenvolvido de forma concisa;

b)Justificativa - explicitar a escolha do tema e como ele se relaciona com o momento da aprendizagem;

c)Definição do conteúdo de aprendizagem - os objetivos e conteúdos específicos devem estar claros, pois deverá haver o desenvolvimento de conceitos, de procedimentos e de atitudes dos envolvidos no processo de ensino/aprendizagem em direção ao objetivo geral da disciplina;

d)Diretivas para o desenvolvimento do projeto - devido à imaturidade dos educandos, talvez seja necessário à explicitação de etapas e encaminhamento de estratégias para o desenvolvimento da pesquisa que antecede a execução do projeto;

e)Avaliação - deverá ser estabelecida de acordo com os critérios e indicadores para a avaliação (relacionando-os aos objetivos e conteúdos) e utilizados instrumentos considerados adequados para a análise do desempenho individual, do grupo e do "produto" realizado.

O planejamento deve levar em consideração a atribuição de sentido a uma situação de aprendizagem específica. É vital que os educandos encontrem um sentido no que estejam desenvolvendo, pois isso é condição primordial para seu desenvolvimento global, que integra a dimensão intelectual da personalidade/ habilidades na dimensão de valores, de afetividade, de relacionamento e de desempenho profissional. 


\subsubsection{Uso adequado do projeto e sua relação com a teoria das Inteligências Múltiplas}

A estratégia de projetos visa, dentre outras coisas, estreitar a relação entre o contexto em que está inserido o conteúdo da disciplina e sua fundamentação teórica. O aprender participando, vivenciando sentimentos, tomando atitudes diante dos fatos, escolhendo procedimentos e atingindo determinados objetivos, ou seja, o processo de aprendizagem ligado às práticas profissionais cotidianas.

O projeto é uma atividade intencional que possibilita o envolvimento efetivo do educando com a disciplina e com os grupo da sala de aula.

Através dessa estratégia os educandos se tornam co-responsáveis conscientes da aprendizagem e desenvolve, de forma eficiente, o sentido de cooperação que deverá estar associado ao trabalho profissional.

O objetivo central do projeto constitui um problema ou fonte geradora de problemas, que exige, para ser solucionado, uma intervenção, conhecimento e uma estratégia.

Essa estruturação do raciocínio na elaboração e no desenvolvimento do projeto se torna extremamente rica para o desenvolvimento de habilidades necessárias ao profissional de engenharia que serão requeridas no exercício da profissão.

Realizar projetos faz parte das atividades profissionais de um engenheiro e dentro disso há todo um processo de desenvolvimento pessoal/profissional/técnico a ser adquirido que vai do entendimento do tema à redação dos resultados obtidos.

As etapas sugeridas por etapas LOURENÇO (1978), NÉRICI (1992), AGUAYO (1986) e LEITE (1996) podem exemplificar as possibilidades do desenvolvimento de algumas habilidades de forma consciente e monitorada pelo educador, tendo como direcionamento desse objetivo as Teorias das Inteligências Múltiplas. 


\section{Etapa 1: Problematização}

Na primeira etapa, inicia-se o desenvolvimento da inteligência lógica e interpessoal.

A inteligência lógica é estimula durante todo o processo de escolha e elaboração do tema, pois essa tarefa deverá ser realizada dentro do contexto educacional que está inserido a Instituição de Ensino Superior e para isso variáveis diferenciadas devem ser levadas em consideração.

A inteligência interpessoal também tem seu processo consciente de desenvolvimento iniciado nessa etapa. Nessa fase, há a elaboração dos grupos de execução, quando a cooperação e a liderança começam a ser estimulada.

A partir dos grupos formados, haverá o início do processo de planejamento. Essa talvez seja a fase mais importante de todo processo, pois dependerá dela a facilidade com que outras atividades de desenvolvimento ocorrerão.

$\mathrm{Na}$ atividade de planejamento todos deverão participar efetivamente dando sugestões e indicando modos de realização da atividade. As inteligências pessoais e a inteligência lógica são constantemente estimuladas.

Nesse momento poderá ser sugerido que escrevam as estratégias a serem seguidas discutidas no momento anterior estimulando assim a inteligência lingüística. O educador deverá estimular a leitura e escrita de forma mais correta possível, incentivando-os ao uso do dicionário, o uso de palavras específicas relacionadas ao tema e principalmente. A ele cabe a tarefa de correção minuciosa desse material entregue e a sugestão de modificações e correções que poderão ser conscientizadas para um próximo trabalho.

Esse material entregue poderá ser utilizado para estudos posteriores sobre como descrever estratégias de ação e como isso ocorre dentro do mercado de atuação profissional, independentemente da disciplina em 
questão. Descrições de estratégias, redação de planejamentos operacionais seguem padrões e podem ser abordados em diversas disciplinas com a finalidade de preparar o profissional para a realidade e para as circunstâncias a serem superadas no mercado.

Na TABELA 7.11 há a descrição das atividades sugeridas e as inteligências estimuladas.

TABELA 7.11: Projeto - Problematização: atividade e inteligências estimuladas

\begin{tabular}{|l|l|}
\hline \multicolumn{1}{|c|}{ Atividade } & \multicolumn{1}{c|}{ Inteligências } \\
\hline Selecionar elaborar o projeto: & $\begin{array}{l}\text { Inteligências pessoais } \\
\text { Inteligência lógica }\end{array}$ \\
\hline $\begin{array}{l}\text { Planejar os detalhes para o } \\
\text { desenvolvimento do projeto }\end{array}$ & $\begin{array}{l}\text { Inteligência lógica } \\
\text { Inteligências pessoais }\end{array}$ \\
\hline $\begin{array}{l}\text { Escolher o passo inicial para o } \\
\text { desenvolvimento }\end{array}$ & $\begin{array}{l}\text { Inteligência lógica } \\
\text { Inteligências pessoais } \\
\text { Inteligência lingüística }\end{array}$ \\
\hline
\end{tabular}

\section{Etapa 2: Desenvolvimento}

Após todo o processo de escolha do tema, planejamento da estratégia e opção pelo melhor caminho inicial, a atividade de produção efetiva em direção ao objetivo proposto tem seu começo.

A estratégia já foi criada e hipóteses já foram discutidas, começa-se então a procura pelo material que dará sustentação teórico/prático da atividade a ser desenvolvida. Nesse momento são estimuladas: a inteligência lógica - estruturação do material a ser obtido; inteligências pessoais - estruturação da coleta desse material em grupo e a inteligência lingüística - desenvolvida conforme os indivíduos vão lendo o material obtido. 
À parte de verificação da veracidade das hipóteses levantadas, das estratégias sugeridas e a partir da obtenção de novos dados reavaliar as hipóteses e estratégias planejadas faz com que as inteligências - lógicas, lingüísticas e pessoais sejam solicitadas o tempo todo.

$\mathrm{Na}$ TABELA 7.12 há a descrição das atividades sugeridas nessa etapa e a discriminação das inteligências estimuladas.

TABELA 7.12: Projeto - Desenvolvimento: atividade e inteligências estimuladas

\begin{tabular}{|c|c|}
\hline Atividade & Inteligências \\
\hline $\begin{array}{l}\text { Recolher os dados do problema ou fatos de } \\
\text { uma situação de acordo com a estratégia } \\
\text { planejada }\end{array}$ & $\begin{array}{l}\text { Inteligência lógica } \\
\text { Inteligências pessoais } \\
\text { Inteligência lingüística }\end{array}$ \\
\hline $\begin{array}{l}\text { Observar esses fatos para situar ou } \\
\text { esclarecer a questão proposta }\end{array}$ & $\begin{array}{l}\text { Inteligência lógica } \\
\text { Inteligência intrapessoal } \\
\text { Inteligência lingüística }\end{array}$ \\
\hline Elaborar uma hipótese ou solução possível & $\begin{array}{l}\text { Inteligência lógica } \\
\text { Inteligências pessoais }\end{array}$ \\
\hline Escolher uma das hipóteses elaboradas & $\begin{array}{l}\text { Inteligência lógica } \\
\text { Inteligências pessoais } \\
\text { Inteligência lingüística }\end{array}$ \\
\hline Verificar a confirmação e aplicação & $\begin{array}{l}\text { Inteligência lógica } \\
\text { Inteligências pessoais }\end{array}$ \\
\hline $\begin{array}{l}\text { Coletar informação e selecionar o material } \\
\text { necessário para a execução das diversas } \\
\text { fases do planejamento e da comprovação das } \\
\text { hipóteses }\end{array}$ & $\begin{array}{l}\text { Inteligência lingüística } \\
\text { Inteligência lógica }\end{array}$ \\
\hline Executar as tarefas previstas & $\begin{array}{l}\text { Inteligência lógica } \\
\text { Inteligências pessoais }\end{array}$ \\
\hline
\end{tabular}




\section{Etapa 3: Síntese}

Essa é a fase onde os trabalhos serão apresentados e onde poderão ser monitorado, mais de perto, o aprimoramento de atitudes e posturas dos indivíduos pertencentes aos grupos de ação.

Ao educador fica a responsabilidade de optar pela simples entrega do projeto realizado e/ou apresentação aos demais integrantes da sala. A segunda opção é sempre a mais interessante e a que possibilita uma análise efetiva e real de todo processo planejado, assim como o desempenho individual de cada integrante do grupo.

Podem ser também integradas ao desenvolvimento da estratégia projetos as considerações feitas na fase 5 da estratégia seminário, sobre posturas durante a apresentação, tom de voz, utilização de recursos - mais à parte da criatividade individual, pois, poderá ser necessária uma improvisação de recursos.

A apresentação do projeto ao grupo se faz necessária para que haja conhecimento, por parte de todos os integrantes da disciplinas, das atividades planejadas, realizadas e dos objetivos alcançados.

Nessa fase a inteligência lingüística é fortemente estimulada, pois a apresentação dos objetivos e produtos à sala requer um domínio diferenciado de linguagem.

Antes das apresentações - em aulas anteriores - podem ser abordadas técnicas de apresentações de projetos, cuidados com a linguagem e com posturas físicas - inteligência corporal, dentre outras, já direcionando essa atividade ao desenvolvimento de inteligências complementares - inteligência lógica, Inteligência lingüística e inteligências pessoais.

Após a apresentação, ou em aulas posteriores, poderão ser analisadas as estratégias planejadas e as efetivamente executadas, confrontando o planejamento com o executado. Essa análise estimula a consciência de atitudes profissionais e pessoais que auxiliarão no 
desenvolvimento das habilidades de trabalhar em equipe - inteligências pessoais; expressão verbal e escrita - Inteligência lingüística; e integração dos conhecimentos adquiridos aos antigos servindo como base para os futuros - inteligência lógica.

Na TABELA 7.13 há a descrição das atividades sugeridas nessa etapa e a discriminação das inteligências estimuladas.

TABELA 7.13: Projeto - Síntese: atividade e inteligências estimuladas

\begin{tabular}{|l|l|}
\hline \multicolumn{1}{|c|}{ Atividade } & \multicolumn{1}{|c|}{ Inteligências } \\
\hline $\begin{array}{l}\text { Apresentação do projeto/conclusão à } \\
\text { sala }\end{array}$ & $\begin{array}{l}\text { Inteligência lingüística } \\
\text { Inteligência lingüística } \\
\text { Inteligências pessoais }\end{array}$ \\
\hline $\begin{array}{l}\text { Avaliação do trabalho e incentivo a } \\
\text { posturas profissionais }\end{array}$ & $\begin{array}{l}\text { Inteligência lingüística } \\
\text { Inteligência lógica } \\
\text { Inteligências pessoais } \\
\text { Inteligência corporal }\end{array}$ \\
\hline $\begin{array}{l}\text { Expor o projeto para diferentes públicos } \\
\text { e locais }\end{array}$ & $\begin{array}{l}\text { Inteligência lingüística } \\
\text { Inteligência lógica } \\
\text { Inteligências pessoais } \\
\text { Inteligência corporal }\end{array}$ \\
\hline
\end{tabular}

A estratégia de projetos é uma das mais antigas que existem, mas sua aplicação dentro do conceito da Teoria das Inteligências Múltiplas com o objetivo de capacitar melhor o indivíduo tanto técnico quanto em habilidades dá uma nova concepção à atividade, renovando-a.

Os projetos são processos contínuos que não podem ser reduzidos a uma lista de objetivos e etapas fixas, assim como não se deve deixar de utilizar as suas fases como ferramenta de ensino e não somente o produto final desenvolvido por ele. 
Os produtos e atividades relacionadas refletem o conhecimento como produção coletiva, onde a experiência vivida e a produção cultural sistematizada se entrelaçam, dando significado às aprendizagens construídas.

Pensar numa prática pedagógica a partir dos projetos, tirando vantagem de todas as etapas que podem ser observadas traz mudanças significativas para o processo de ensino/aprendizagem.

Dessa forma, há a construção de uma prática pedagógica centrada na formação global dos educandos, formação essa relacionada à parte teórico/prática da profissão e das habilidades necessárias para a inserção e do profissional de engenharia no mercado profissional.

O desenvolvimento de projetos, com o objetivo de resolver questões relevantes para o grupo, gera necessidades de aprendizagem; e, nesse processo há a interligação dos conteúdos de diversas disciplinas, incluídos no processo, involuntariamente, propiciando uma maior efetividade na formação teórico/prático do profissional e sua permanência no mercado de trabalho ao qual pertencerá. 
CAPÍtulo 8

\section{CONCLUSÃO}

Não há dúvida de que no processo educacional a educação pode acontecer de diferentes maneiras, locais ou motivos, mas principalmente acontecer através das interações entre pessoas e com o meio.

Todo processo educacional presencial, dentro do ambiente de sala de aula, é uma atividade triádica que envolve três componentes: aquele que ensina, aquele a quem se ensina, e aquilo que o primeiro ensina ao segundo - conteúdo.

O processo de ensino com qualidade pode ser garantido por aquele que ensina através da utilização de estratégias diferenciadas na transmissão de conteúdos específicos. Nesses conteúdos específicos devem ser inseridas as capacitações pessoais, pois, essa junção, torna-se fundamental para o exercício de atividades profissionais.

Essas necessidades de capacitações técnicas e habilidades (inter) pessoais foram sendo delineadas pelo processo de mudança ocorrido no contexto socioeconômico mundial.

O fato de que a aplicação prática de certas técnicas de gestão moderna exige competências interpessoais específicas para sua aplicação é uma das justificativas de que só a capacidade técnica não é suficiente nesse momento. 
Se o processo de ensino de conteúdo é garantido pela utilização das estratégias de ensino, uma pergunta poderia ser colocada: como garantir o desenvolvimento, concomitantemente, dessas habilidades interpessoais?

\subsection{Como garantir o desenvolvimento, concomitantemente, de habilidades pessoais no ensino de engenharia?}

Essa pergunta direciona a novas investigações a fim de garantir o processo de ensino/aprendizagem vigente.

Nesta direção, a Teoria das Inteligências Múltiplas funciona como uma das ferramentas possíveis de ser agregada ao processo como uma forte aliada no desenvolvimento de habilidades interpessoais, minimizando as diferenças e exigências do mercado.

Essa teoria tem como proposta o desenvolvimento de um indivíduo completo, considerando habilidades específicas e estimulando a capacidade de assimilação de conteúdos de forma natural, assim como a habilidade de resolver conflitos pessoais e profissionais de forma equilibrada e a capacidade de trabalhar em equipe, dentre outras.

O direcionamento da aplicação de uma estratégia pela Teoria das Inteligências Múltiplas possibilita ao educador ampliar o alcance pedagógico do conteúdo e os aspectos operacionais do processo de ensino/aprendizagem

Se a proposta das universidades é colocar pessoas no mercado de trabalho com a melhor capacitação possível, nada mais justificável que isso ocorra no momento onde há uma maior predisposição a estímulos diferenciados que provoquem uma formação sólida e eficaz, isto é, durante o processo de formação.

É pensando nisto que os educadores devem ser estimulados a lançarem mão de todas as possibilidades e recursos, procurando uma 
perfeita formação do estudante de engenharia ao mercado, sem esquecer contudo do compromisso com a sociedade, no tocante ao melhoramento do ser humano.

O que a inserção da Teoria das Inteligências Múltiplas favorece, como mais uma variável para o desenvolvimento das estratégias dentro da sala de aula, é a criação de ambientes ricos em possibilidades de ensino facilitando a aprendizagem, onde pessoas possam ser motivadas a aprender e a se desenvolver enquanto ser humano e sem negligenciar a experiência adquirida pelo educador como facilitador do processo educacional.

\subsection{Observações finais}

A Teoria das Inteligências Múltiplas funciona como um direcionamento para a prática de ensino. Esse direcionamento facilita o desenvolvimento da atividade de ensino objetivando o estímulo das habilidades pessoais.

A Teoria das Inteligências Múltiplas pode facilitar a execução das práticas de ensino e seu planejamento, tendo como referencial, além do conteúdo e estratégias, o alcance dos objetivos propostos pela disciplina. Essa constatação deve-se à consideração consciente do desenvolvimento e da existência de características individuais dentro do ambiente de sala de aula.

A preocupação do desenvolvimento individual sem esquecer do grupal é possível devido ao fato de haver a flexibilidade de se co-relacionar tipos de inteligências. Um exemplo seria o estímulo da inteligência interpessoal é facilitado quando a intrapessoal está sendo estruturada.

O processo da aplicação das estratégias: aula expositiva, seminário e projetos, direcionados também pela Teoria das Inteligências Múltiplas, tornase mais trabalhoso num primeiro momento, pois o educador deverá planejar suas atividades não só pensando e dimensionando tempo disponível e conteúdo, mas também condutas e estilos do educador e dos educandos. 
Por exemplo, na estratégia de projetos, não basta apenas sugerir temas, direcionar os envolvidos durante a execução e avalia-los ao final da entrega do trabalho. Após a entrega poderão ser trabalhadas outras partes que compuseram toda a atividade como planejamento, posturas pessoais e grupais antes, durante e depois do trabalho concluído, analisar, não somente o projeto em si, mas todas as etapas e variáveis que o compõe como: os relatórios, as decisões tomadas,as técnicas utilizadas, etc. Assim, o professor tem de estar bem preparado, não só para a avaliação do projeto em si, mas de todas as etapas, tudo isso dentro de um limite de tempo disponível, ou ocorrerá em erros e dificuldades que, eventualmente, poderão ser encarados como falta de habilidade do professor em relação ao conteúdo da disciplina.

A preparação é fundamental, pois poderá colocar em dúvida o conteúdo e a capacidade do educador, provocando, no educando, a sensação de que nada foi apreendido - nem conteúdo, nem habilidades.

Trabalhar e discutir condutas, estratégias, planejamento pode ser uma tarefa emocionante, mas a consciência de que não existe, entre elas, uma totalmente certa ou errada pode levar o educador à super ou subestimá-las.

O que existe são estilos e técnicas que podem ser aplicadas de acordo com valores e experiência de quem as aplica. Portanto, a discussão deve ser bem coordenada dentro de um limite de tempo e espaço (situação) e em direção a um objetivo claro, que pode ser o de mostrar alternativas para mesmas situações ou de discutir os estilos e conseqüências, trazendo sempre para o concreto (realidade) todos os tópicos trabalhados.

A partir das discussões, objetivando o desenvolvimento de determinadas inteligências, o que se pode obter são indivíduos mais comprometidos e motivados com as próximas atividades a serem executadas por visualizarem nelas possibilidades efetivas de crescimento técnico e pessoal. Esse crescimento inclui tanto o educando quanto o educador que passará a perceber, de forma mais clara, a sua necessidade de se aprofundar em assuntos que não estão diretamente ligados ao seu 
conteúdo programático mas que facilitam seu processo de ensino e o atendimento dos objetivos propostos - a interdisciplinaridade.

Dentro do contexto de ensino de engenharia, esse trabalho transforma-se em um material a disposição de pessoas preocupadas com a qualidade de ensino e a efetiva formação do educando, pessoal e profissional. E permite que novos embasamentos teóricos e conceituais sejam incorporados à prática de ensino e a Teoria das Inteligências Múltiplas garantindo a melhoria constante do processo de formação dos educandos, potencializando práticas e técnicas educacionais consagradas no ensino de engenharia.

\subsection{Perspectivas Futuras}

É crescente a preocupação, no ensino de engenharia, quanto à qualidade e possibilidade de desenvolvimento de habilidades técnicas e pessoais e interpessoais que facilitem a capacitação e conseqüentemente a inserção do profissional no mercado de trabalho, de forma diferenciada.

Nesse trabalho houve a preocupação de não negligenciar nenhuma das experiências e habilidades desenvolvidas e existentes nos professores dos cursos de graduação em engenharia, propondo ações que se ajustam, de forma natural, às já exercidas e executadas.

A Teoria das Inteligências Múltiplas tem uma grande aplicabilidade na área educacional, possibilitando pesquisas futuras no sentido de detalhar como as atividades propostas, dentro das estratégias escolhidas, interagem com os estilos pessoais de ensino/aprendizagem e qual sua interligação com o ciclo de aprendizagem (por que, o que, como, e se), objetivando minimizar algumas variáveis que possam vir afetar a qualidade de educação em engenharia. Trabalhos que irão investigar essas relações na prática e que ofereçam mecanismos de melhoria uma vez que esse trabalho limitou-se a aspectos teóricos. 
Uma outra perspectiva para esse trabalho é analisar como a Teoria das Inteligências Múltiplas se comporta, no ensino superior, quando novas tecnologias são inseridas no ambiente tradicional de ensino - sala de aula modificando a dinâmica das estratégias. É o caso do que poderia ser realizado no ambiente de Educação à Distância - sala de aula virtual objetivando a melhoria na formação pessoal do indivíduo através das perspectivas da teoria.

O trabalho foi elaborado sobre o foco nas estratégias utilizadas pelo educador no processo de ensino. Uma das possibilidades de um novo trabalho seria verificar como a Teoria das Inteligências Múltiplas poderia ser utilizada no contexto da aprendizagem.

Tendo como foco direcionador a Teoria das Inteligências Múltiplas, avaliar o processo de ensino/aprendizagem ocorrido em outros níveis de ensino como segundo grau, cursinho, etc e verificar como elas estão relacionadas ao processo de aprendizagem e ensino. Nessa avaliação a comparação do que já é realizado com sucesso em outros níveis e como isso poderia ser incorporado nos cursos superiores poderia ser realizado, usando a flexibilidade da Teoria das Inteligências Múltiplas para a incorporação dessas estratégias ao processo de formação dos profissionais nos cursos superiores.

Dentro das empresas a consciência sobre as vantagens da aprendizagem coorporativas, muitas vezes chamadas de e-learning, está cada vez mais sendo utilizada. No treinamento empresarial essa técnica tem se mostrado extremamente útil. O treinamento empresarial engloba não somente capacidades técnicas mais pessoais. A partir da análise dos conceitos de e-learning e de como esse processo de ensino/aprendizagem a distancia ocorre, poderia ser avaliada a contribuição da Teoria das Inteligências Múltipla nesse processo específico de capacitação profissional.

A partir de referenciais do Ministério da Educação e Cultura e de outras entidades de classe como ABENGE - Associação Brasileira do Ensino de Engenharia, ABEPRO, etc. sobre as características que os 
profissionais de engenharia deverão desenvolver para preenchera a demanda do mercado vigente verificar como a Teoria das Inteligências Múltiplas pode ser utilizada para cursos de específicos de engenharia (civil, mecânica, produção, etc.).

A possibilidade de trabalhar uma disciplina específica e verificar as habilidades técnicas e pessoais que poderiam ser desenvolvidas efetivamente utilizando a Teoria das Inteligências Múltiplas para o direcionamento ao alcance dos objetivos específicos e gerais da disciplina.

Basicamente, a Teoria das Inteligências Múltiplas pode ser incorporada a qualquer área do conhecimento. No processo de formação e educação profissional e pessoal pode se tornar uma forte aliada para avaliação de processos e de possibilidades para o alcance da excelência do ensino superior. 


\section{REFERÊNCIAS BIBLIOGRÁFICAS}

(2000) Intelligence Reframed: Multiple Intelligences for the 21st Century http://www.sbce.on.ca/mit (10/Out).

ABREU, M. C. T. A. (1975). O papel do professor das disciplinas Ocomuns do primeiro ciclo de ciências humanas e educação da PUCSP, na concepção dele mesmo. São Paulo, 169p. Dissertação (Mestrado) Faculdade de Psicologia, Pontifícia Universidade Católica de São Paulo.

AGUAYO, A.M. (1986). Didática da escola nova. São Paulo, Companhia Editorial Nacional.

ALMEIDA, M.E. (1996). Informática e educação: reflexões sobre a formação de professores para o uso pedagógico do computador. São Paulo, 165p. Dissertação (Mestrado) - Faculdade de Educação, Pontifícia Universidade Católica de São Paulo.

ALMEIDA, M.E. (1997). O computador como ferramenta de reflexão na formação e na prática pedagógica. APG, v. 11, p. 127-135, Abr.

ARAUJO, G.D.; BORDONI, T. C.; VALENTIM, M.A. (1998). Revisão de pesquisas realizadas no Brasil sobre o uso de computadores em educação. http://netpage.em.com.br/mines/revisão.htm (24/Set.).

BARKMAN, R. (1997). Patterns and the eighth intelligence. http://www.newhorizons.org/trm_mipattern.html (26/Jan.). 
BARROS, A. J. S. (2000) Fundamentos de Metodologia. São Paulo, Makron Books.

BARROS, A. J. S. (1994) Fundamentos de Metodologia. São Paulo, Makron Books.

BERBEL, N. A. N. (1994). Metodologia do ensino superior: realidade e significados. Campinas, Papirus.

BORDENAVE, J. D.; PEREIRA, A. M. (1978). Estratégia de ensino aprendizagem. Petrópolis, Vozes.

CHENAIS, F. (1996). A mundialização do capital. Xamã, São Paulo.

COLENCI, A. JR, (1996). Organizar as instituições para se assegurar qualidade no ensino de engenharia. In: CONGRESSO BRASILEIRO DE ENSINO DE ENGENHARIA. 24; Anais. Manaus, ABENGE/Universidade do Amazonas.

COLENCI, A.T. (2000). O ensino de engenharia como uma atividade de serviços: a exigência de atuação em novos patamares de qualidade acadêmica. São Carlos, 129p. Dissertação (mestrado) - Escola de Engenharia de São Carlos, Universidade de São Paulo.

DAVIES, I. K. (1979). O planejamento do currículo e seus objetivos. São Paulo, Saraiva.

ERST, R.S. (1996). Technical and skills training in a learning organization. Manufacturing Agility and Hybrid Automation. n.7, p.50-52, Mar.

FAGUNDES, M.; GONÇALVES, C. (1997). Conhecimentos pedagógicos específicos. Ribeirão Preto, Prefeitura Municipal De Ribeirão Preto. 76p./Apostila/.

FOGARTY, R. (1997). Brain compatible classrooms. Arlington, Skylight Training and Publishing. 
FREIRE, P (1987). Pedagogia do oprimido. Rio de Janeiro, Paz e Terra.

FREITAS, B. (1998). Escola, estado e sociedade. São Paulo, Cortez e Moraes.

GARDNER, H. (1994). Estruturas da mente: a teoria das inteligências múltiplas. São Paulo,Artes Médicas.

(1995). Inteligências múltiplas: a teoria na prática. São Paulo, Artes Médicas.

(1997). Truth, beauty, and goodness: an education for all human. Beings. http://www.edge.org/3rd_culture/gardner/gardner_p2.html (26/Mai).

GARDNER, H.; KORNHABER M., WAKE W. (1998). Inteligência: múltiplas perspectivas. Porto Alegre, Artes Médicas.

GARDNER, H. (2000). Curriculum. http://www.ed.psu.educação/ ae-insyswfed/INSYS/ESD/Gardner/curricul.html (08/Ag.).

GIL, A.C. (1994). Metodologia do ensino superior. São Paulo, Atlas.

GODOY, A. S. (1988). Didática para o ensino superior. São Paulo, Iglu.

GOMES, J.R.P.; MORO, J.R. (1996). Aspectos didáticos-pedagógicos que auxiliam na execução de uma metodologia educacional. . In: CONGRESSO BRASILEIRO DE ENSINO DE ENGENHARIA, 24; Anais. Manaus, ABENGE/Universidade do Amazonas.

GOMES, M. T. (1998). Aprenda a Escolher Gente de Talento com Paulo Ferraz, da Bozano. Você S.A. v.2, p.18-9, Jan.

MACHADO, L. A. (1994). Criatividade, educação e competitividade empresarial. Qualimetria. n. 32, p.11-13, Abr.

HAPE, R. (1997). Consciência é a resposta. São Paulo, Talento. 
HO C.; LU I. (1996) The role of engineering design. Massachusett, 122p. Monografia - Faculdade de Engenharia Mecânica, Massachusett Institute of Technology (MIT).

JANNI, O. (1996). Teorias da globalização. São Paulo, Civilização Brasileira.

JOLIBERT, J. (1994) Formando crianças leitoras. Porto Alegre, Artes Médicas.

KURI, N.P. e GIORGETTI, M. F. (1994). Metodologia do ensino de engenharia - planejamento de ensino. São Carlos, Centro de Tecnologia Educacional para Engenharia . 52p./Apostilas/.

LEITE, L.H.A. (1996). Os projetos de trabalho, o espaço escolar e a formação dos alunos. Presença Pedagógica. v.2, n8, p.168-80, Mar/Abr.

LIBÂNEO, J. C. (1994). Didática. São Paulo, Cortez.

LOGAREZZI, A., LOGAREZZI, A.M.. (1996). Novos Professores para novos engenheiros. In: CONGRESSO BRASILEIRO DE ENSINO DE ENGENHARIA, 24; Anais. Manaus, ABENGE/Universidade do Amazonas.

MACHADO, L. A. (1994). Criatividade, educação e competitividade empresarial. Qualimetria. n. 32, p.11-13, Abr.

MACHADO. N.J. (1995). Concepções de inteligência: dos testes de QI ao espectro de competência. http://www.puepr.br/intitulos/sinepe//palenj.htm. (25/Jan.).

MAGNOLI, D M. (1983). O que é geopolítica. São Paulo, Brasiliense.

MARQUES, J.C. (1976). Os caminhos do professor. Porto Alegre, Globo.

MARTINHO, L. A. P. (1994). Rompendo paradigmas. Qualimetria, n. 38, p.42-43, Out.

MARTINS, J.P. (1990). Didática geral. São Paulo, Atlas. 
MASETTO, M. T.; ABREU, M. C. (1990). O professor universitário em aula: prática e princípios teóricos. São Paulo, Mg Associados Ltda

MEDEIROS, J.B. (1997) Redação Científica: a prática de fichamento, resumos, resenhas. São Paulo. Atlas.

MELLO (1997). Inteligências Múltiplas - processo educacional e suas possibilidades.

http://www.homemdemello.com.br/psicologia/intelmult.html (4 Dez.).

MILLER, G.E. (1967). Ensino e aprendizagem nas escolas médias. São Paulo, Companhia Editora Nacional.

MOREIRA, D.A., org. (1997) Didática do ensino superior: técnicas e tendências. São Paulo, Pioneira.

MORGAN, R.P.; REIDE P.P.; WULF W.A. (1998). The changin nature of engineering implication for engineering education http://www.asee.org/pubs/html/changing.htm (26/Abr.).

MORAN (1997) The theory of multiples intelligences (MI). http://www.eng_moran.educação/mahmud/ed.html. (11/May.).

NÉRICI, I.G. (1986). Didática geral dinâmica, São Paulo, Atlas.

NÉRICI, I.G. (1992). Metodologia do Ensino:uma introdução. São Paulo, Atlas.

PAPERT, S. (1994). A Máquina das crianças. Porto Alegre, Artes Médicas.

PASSARELLI, B. (1996). Teoria das Múltiplas Inteligências \& Multimídia na Educação: Novos Rumos para o Conhecimento. http://www.apple.com.br/html/brasilina (03/Dez.).

PEREIRA, M.E. (1999). História da psicologia. http://www.geocities.com/Ahens/Delphi/6061//inha.html. (25/Ago.). 
PETTERSON, G. (1998). Criteria 20000 - A bold new change agent. http://www.asee.org/pubs/html/criteria2000.htm (26/Abr.).

POWELL, J. (1998). What is new in assessment and evaluation? publishers@powells.com (26/Jan).

RIBEIRO, N. (1998). Uma prática para o desenvolvimento das múltiplas inteligências: aprendizagem com projetos. São Paulo, Érica.

RIPPER, A. V. (1996). O preparo do professor para as novas tecnologias. In: OLIVEIRA, V.B. (1996) Informática em Psicopedagogia. São Paulo,. Senac, Cap. 3, p. 57-83.

SHELTON, L. (2000). Multiples intelligences for adult literacy and adult education. http://www.literacynet.org/diversity/howwelearn.html (23/Mar.)

SMOLE, K. (1996). A Matemática na Educação Infantil: A Teoria das Inteligências Múltiplas na Prática Escolar. Porto Alegre, Artes Médicas.

SMOLE, K. (1996). A Matemática na Educação Infantil: A Teoria das Inteligências Múltiplas na Prática Escolar. Porto Alegre, Artes Médicas.

SMOLKA, A.L.B. (1988). A criança na fase inicial da escrita: a alfabetização como processo discursivo. São Paulo, Cortez.

STANLEY, S. (1997). Multiple intelligences. http://www.valdosta.peachnet. educação/coed/second/GAIT/inf013.html (27/Jan).

SWIFT, D. F.(1997). A Sociologia da educação. São Paulo, Atlas.

TRACY, K. (2001) How To Enhance The Classroom Curriculum. http://teachers.net/gazette/OCT00/tracy.html. (02/mar.).

TURRA, C. M. G. (1982). Planejamento de ensino e avaliação. Porto Alegre, Sagra. 
VICTOR, G. (1997). Paradigmas: como ver através?. http://www.elogica.com.br/users/vitorg, (01/Out).

WENK, E. Jr. (1998). Teaching engineering as a social science http://www/asse.irg/pubs/social.htm (01/Out.). 


\section{BIBLIOGRAFIA COMPLEMENTAR}

(2001) Diretrizes curriculares para os cursos de engenharia.

http://www.mec.gov.br/sesu/ftp/curdiretriz/engenharia/eng_dire.rtf. (20/07) (2001) Engenharia de produção: grande área e diretrizes curriculares. http://www.abepro.org.br/cursos.htm (20/07).

BARBIERI, F.E. (1997). O engenheiro no contexto da globalização. In: CONGRESSO BRASILEIRO DE ENSINO DE ENGENHARIA, 25; Anais. Salvador, v1, p 271- 277.

BAZZO, W.A., PEREIRA, L.T.V. (1997). O jogo da criatividade, In: CONGRESSO BRASILEIRO DE ENSINO DE ENGENHARIA, 25; Anais. Salvador, v1, p 177- 191.

BELHOT, R. V, (1997). Experiência com o Ensino Apoiado por Computador, In: CONGRESSO BRASILEIRO DE ENSINO DE ENGENHARIA, 25; Anais. Salvador, v1, p 127- 134.

BLANDIN, B. (1995). Open Learning: Beyound The Ins. European Jounal of Engineering Education, vol.20, n.2, p.187-193, Mar.

BRANDÃO, L.P.M.; LEITE, L.S.; MARTINS, A.S.; VIEIRA, M.L.S.; LIMA, J.R.S.; SAMPAIO, M.N. (1996). Revendo Papéis no Processo Educativo. In: CONGRESSO BRASILEIRO DE ENSINO DE ENGENHARIA, 24; Anais. São Paulo, v.1, p.391-399. 
CAMPBELL, B. (1997). The Naturalist Intelligence. http://www.newhorizons.org/ article_eighthinel.html. (26/Jan.).

CHIGANER, L.; BOGOSSIAN, F. (1996). O Ensino de Engenharia na nova sociedade. In: CONGRESSO BRASILEIRO DE ENSINO DE ENGENHARIA, 24; Anais. São Paulo, v.2, p.39-47.

DURIE, R. (1997). Mindshift Conection: Multiples Intelligences. http://zephypres.com/gardner.html (26/Jan)

FEIJÓ, M.C. (1997) Reeducação dos Sentidos: equilíbrio entre razão e emoção. Qualimetria, n. 65, p. 14-16, Jan.

FERES, L. M. C. (1998). Novas Tecnologias no Processo Educacional. Email. (30/Jan.).

FERREIRA, A.B.H. (1998). Dicionário Aurélio básico da Lingua Portuguesa. São Paulo, Nova Fronteira.

CARDoso, S.M. (1999). As alterações do Mercado de trabalho. http://207.179.119/eva/3/8.html (29/Out.).

GARDNER, H. (1995). Mentes que criam - uma anatomia da criatividade. São Paulo, Artes Médicas.

(1995). Mentes que lideram - uma anatomia da liderança.

São Paulo, Artes Médicas.

(1997). Project Zero. http://www.cyberspace.com/ building/ trm_gardner (21/Jan.).

(1997). Intelligence in seven steps.

http://www.newhorizons.org/erfut_gardner.html. (26/Jan.).

(1997). The unschooled mind. http://www.west.net/ rinsight/london/gardner.htm, (26/Mar.).

(1997). Real geniuses. http://www.pbs.org/newshour/authors corner/july-dec97/gardner_9-17.html (16/Jul.).

Multiples

intelligences.

http://www.inbnet.mb.ca/ lgirling/ inteligênciasmúltiplas.html (20/Oct.). 
(1997). Pressuposições básicas da PNL.

http://www.convex.com.br/pnlinform/faq/htm. (20/Out.)

(1998). Leading minds: an anatomus of leadership http//infoweb.magi.com/ pmre/Newsletters/IS3-4.htm (10/Oct.).

(1998). A personal exploration of the life of virginia wolf as compared to howard gardner's model of creativity. http//www.miavx1.muojio.educação/ shermalw/george.html (27/Jan). (1998). Advice to reformers. http://www.ed.psu.educação/ aeinsys-wfed/INSYS/ESD/Gardner/ advice.html (08/May.).

(1999). Being educated (in 2010).

http://www.ed.psu.educação/ ae-insys-wfed/INSYS/ESD/Gardner/ beingEd.html (08/May.).

(1999). Multimedia literature: multiple intelligences. http://wwwmmhschool.com/products/mlmi5.html (11/Mai).

GODOY, A. S. (1989) Ambiente de Ensino preferido por alunos do terceiro grau: um estudo comparativo. São Paulo. Tese (doutorado). Faculdade de Educação da Universidade de São Paulo.

GOLEMAN, D. (1995). Inteligência emocional. Rio de Janeiro, Objetiva.

GROW. G. (1997). Writing and multiples intelligences. http://168.223.2.3./sjmga/ggrow/7In/Conclusion.html (20/Dec.).

HESSEN, J. (1973). Teoria do conhecimento. Coimbra, Arménio Amado.

HOERR, T. (1995). Apply the theory, avoid the traps /Letter/. USA Leaning, n.8 p.69-71, Aug.

HOERR, T. (1997). The naturalist intelligence. http://www.newhorizons.org/trm_hoerrmi.html. (26/Jan..).

INVERNO, E. (1997). Sete estilos de aprendizagem. http://babelfish.altavista.digital.com/cgi-bin/translate? (27/Jan).

JR., V. M. (1994). O Educador e a criatividade. Qualimetria, n. 32, p..9-10, Abril. 
$\mathrm{KOCH}$, C. (1996). The Bright Stuff. http://cio.com/archive/031596_qa_content.html. (15/Mar/1997).

KOLMOS, A, (1996). Reflection on project work and problem-based learning. European Jounal of Engineering Education, vol.21, n.2, p.141149 , Jun.

KORNHABER, M. KRECHESVSKY, (1994). Expanding definitions of teaching and learning: Notes from the MI underground. New York, Garland Press.

KURY, N.I. (1993). Abordagem do processo de ensino aprendizagem. Centro de Tecnologia Educacional para Engenharia - CETEP. São Carlos $-\mathrm{SP}$.

LAJONQUIĖRE, L. (1993). A transformação das práticas educativas e a oficina de educadores. Educação e Sociedade, n. 46, p. 460-475, Dez.

LEVY, P. (1993). As tecnologias da inteligência. O futuro do pensamento na era da informática. São Paulo, Ática.

LUZ, D. C. (1994). Pessoas e paradigmas. Qualimetria, n. 39, p.62-63, Nov.

MIRSHAWAKA, V. (1995). Encontrando o seu próprio estilo de aprendizado ( ${ }^{\text {a }}$ Parte). Qualimetria, n. 42, p. 34-41, Fev.

MIRSHAWAKA, V. (1995). Encontrando o Seu Próprio Estilo de Aprendizado (2 ${ }^{\text {a }}$ Parte). Qualimetria, n. 43, p.26-29, Mar.

MORAN, J.M. (1994). Interferências dos meios de comunicação no nosso conhecimento. Intercom - Revista Brasileira de Comunicação, v. 27, n.2, p.77-83, Jul.

MUSSO, E. (1997). Intuição e eriatividade. http://www.edie.com.br/consulto.htm (25/Jun).

NOGUEIRA, N.R. (1998). Uma prática para o desenvolvimento das inteligências múltiplas. São Paulo, Érica.

NÉRICI, I. G.(1978). O homem e a educação, São Paulo, Atlas. 
OLIVEIRA, V. B., org. (1996). Informática em psicopedagogia. São Paulo, Senac.

PELLANDA, N.M.C.; PELLANDA, L.E.C. (1998). Mutação antropológica e espaço cibernético: o alcance da obra de Pierre Lévy. http://portoweb.com.br/PierreLevy/pellanda.html. (24/Set.).

PORTER, M.E. (1991). Estratégias competitivas, Rio de Janeiro, Campus.

RICOEUR, Paul, (1969). Reconstruir a universidade. Rio de Janeiro, Civilização Brasileira.

ROGERS. C (1986). Liberdade de aprender em nossa década. Porto Alegre: Artes Médicas.

TOFFLER, A.,\& TOFLER, H. (1998). Ensinar o Século 21. Folha de São Paulo, São Paulo, 8 mar. Caderno Mais, p.5.

VERA, A. A. (1990). Metodologia científica. Porto Alegre, Globo.

VICTOR, G. (1998). A escola e a educação emocional. http://www.regra.com, (01/Out.).

VICTOR, G. (1998). A inteligência emocional a serviço do homem. http://www.elogica.com.br/users/vitorg, (01/Out.).

WILSON, D. (1998). A Nova Mídia. Rio de Janeiro, Civilização. 